Andrea Laplane

\title{
DIREITO, CONCORRENCIA E DESENVOLVIMENTO: A ATUAÇÃO DO CADE NO CASO DA INDÚSTRIA PETROQUÍMICA
}

\author{
Dissertação de Mestrado apresentada ao \\ Departamento de Direito Comercial
}

Orientador: Prof. Dr. Francisco Satiro de Souza Junior

Faculdade de Direito da USP São Paulo

2008 
Andrea Laplane

\section{DIREITO, CONCORRENCIA E DESENVOLVIMENTO: A ATUAÇÃO DO CADE NO CASO DA INDÚSTRIA PETROQUÍMICA}

Dissertação de Mestrado apresentada ao Departamento de Direito Comercial da Faculdade de Direito da Universidade de São Paulo, como requisito parcial para obtenção de título de Mestre.

Orientador: Professor Doutor Francisco Satiro de Souza Junior.

Faculdade de Direito da USP

São Paulo

2008 
Para meus pais e meus irmãos 


\section{RESUMO}

Na presente dissertação, o setor petroquímico é utilizado como mote para um estudo sobre os contornos do direito antitruste nacional, sua interpretação e aplicação à luz das especificidades da economia brasileira. O pano de fundo deste trabalho é o debate, levantado durante os anos 1990, sobre a disciplina da concorrência nos países em desenvolvimento dever ou não seguir as tendências mais contemporâneas das instituições de países de economia mais avançada e com tradição na matéria antitruste. Além da revisão dos conceitos e práticas da regulação da concorrência nos países centrais (e de alguns dos desafios apontados pela literatura acerca da sua aplicação em economias em desenvolvimento), são descritos os traços gerais atribuídos a esse ramo do direito, no ordenamento jurídico brasileiro, focalizando as disposições referentes ao controle das estruturas de mercado. Para contextualizar a pesquisa empírica sobre os atos de concentração apreciados pela autoridade de defesa da concorrência (Conselho Administrativo de Defesa da Concorrência - CADE) envolvendo a petroquímica, abordam-se as características do setor e a trajetória da atuação estatal nesse ramo. Os resultados encontrados apontam que o direito da concorrência complementa, mas não substitui outros instrumentos de política pública necessários à coordenação dos mercados e à promoção de sua competitividade, os quais são especialmente relevantes para as economias em desenvolvimento. 


\begin{abstract}
In this study, petrochemical industry plays the framework for the research about the boundaries of Brazilian competition law, its interpretation and application in the light of the singularities of Brazilian economy. This subject is concerned with the debate raised during the 1990's about the adequacy of the model of competition law and policy advocated by advanced economies for developing countries. In addition of revising the leading concepts and practices on competition law, the main features of Brazilian antitrust law are also described, focusing on the provisions for the control of mergers and acquisitions. With the aim of contextualizing the empirical research about the cases entailing petrochemical firms submitted to the Brazilian Competition Law Council, the characteristics of this industry and the role of public regulation in this field are approached. The results obtained indicate that competition law complements, but does not substitute other instruments of public policy, which are necessary to market coordination and industrial competitiveness. These policies are especially important for the economies of developing countries.
\end{abstract}




\section{AGRADECIMENTOS}

Primeiramente, agradeço ao professor Francisco Satiro de Souza Junior, meu orientador, que desde a graduação me incentiva a seguir atividades de pesquisa acadêmica e tem me auxiliado muito nesse percurso.

Sou igualmente grata ao Programa SYLFF (Sasakawa Young Leaders Fellowship Fund), que além de ter me concedido uma bolsa de estudos, proporcionoume a valiosa oportunidade de conviver e trocar experiências com colegas e docentes de outras áreas. Devo mencionar, em especial, a atenção que me foi dispensada pelos professores Carlos Azzoni e Adalberto Fischmann, da FEA-USP, e por Maria de Lourdes Silva, Secretária Executiva do Programa.

Ao professor Diogo Coutinho, que integrou a banca de qualificação e gentilmente se dispôs a conversar sobre o trabalho em outros momentos, agradeço pelas observações sempre cuidadosas e atentas.

Aos professores das disciplinas que cursei durante a pós-graduação - Calixto Salomão Filho, Eros R. Grau, Luiz Gonzaga Belluzzo, Ricardo Abramovay e Paula Forgioni, que também esteve presente na qualificação - sou grata pela importante contribuição que deram à minha formação.

Registro também minha gratidão a Alberto Salazar Valle e Mario Schapiro, interlocutores fundamentais com quem tive a oportunidade de trocar algumas idéias e indicações bibliográficas, sobretudo na fase inicial deste trabalho.

Devo um especial agradecimento aos colegas e amigos da Fundap, principalmente à Cristina Galvão e Claudia Antico, pela compreensão e pelo apoio que foram fundamentais para que eu pudesse conciliar, durante a maior parte do mestrado, as atividades profissionais e os estudos.

Por fim, agradeço às pessoas que me acompanharam mais de perto ao longo deste processo: meus amigos e amigas (Ana, Bauer, Bel, Ester, Fabricio, Fê, Fer, Gi, Guiba, Lê, Lucia, Rô, Maíra, Marina, Naná e Thalita) e meus familiares, a quem dedico esta dissertação. Obrigada por tudo! 


\section{SUMÁRIO}

INTRODUÇÃO 8

CAPÍTULO 1 - DIREITO DA CONCORRÊNCIA: CONCEITOS, PRÁTICAS E O CONTEXTO DOS PAÍSES EM DESENVOLVIMENTO ........................................... 11

1. A concorrência como objeto de disciplina jurídica: bases econômicas ............. 14

2. $O$ direito para proteger a concorrência: abertura e flexibilidade........................ 18

3. As experiências internacionais de política de concorrência e controle das estruturas de mercado .................................................................................................. 23

3.1 Nos Estados Unidos: da concorrência atomística à eficiência de mercado..... 23

3.2 O paradigma europeu e a idéia de "concorrência-instrumento”..................... 29

3.3 Japão e Coréia do Sul: articulação entre a defesa da concorrência e a política

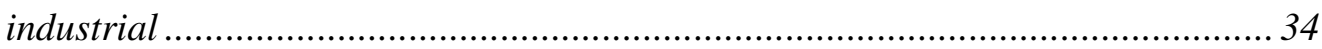

4. A disciplina da concorrência nos países em desenvolvimento ............................. 36

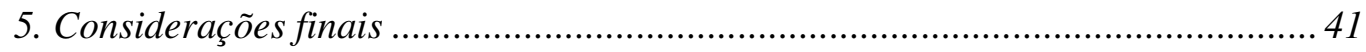

CAPÍTULO 2 - A DEFESA DA CONCORRÊNCIA NO BRASIL................................. 43

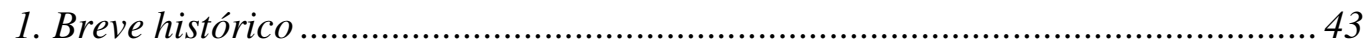

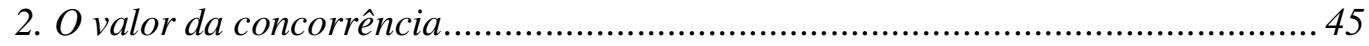

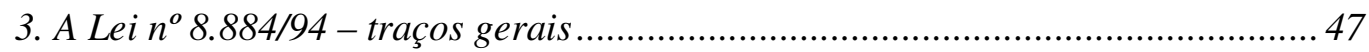

4. O controle de atos de concentração - procedimentos e critérios de análise ......... 48

5. Considerações finais ...................................................................................... 58

CAPÍTULO 3 - O CASO DA INDÚSTRIA PETROQUÍMICA NO BRASIL ..................60

1. Características gerais da indústria petroquímica ................................................. 61

2. As especificidades da indústria petroquímica no Brasil .................................... 72

3. Os mecanismos de regulação estatal na indústria petroquímica brasileira em

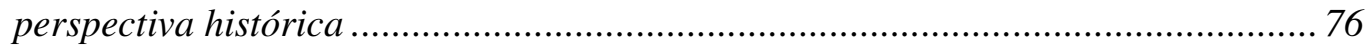

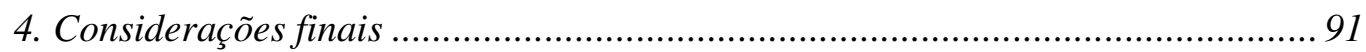


CAPÍTULO 4 - O DIREITO DA CONCORRÊNCIA APLICADO AO SETOR

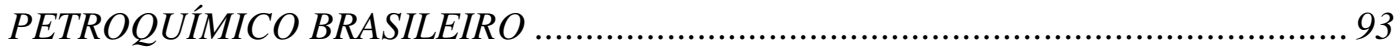

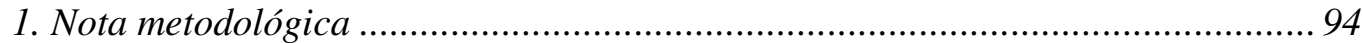

2. Breve panorama sobre a reestruturação recente na indústria petroquímica

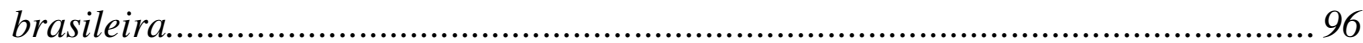

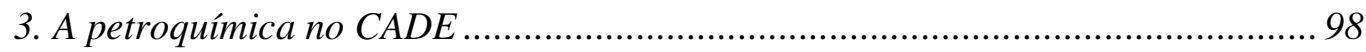

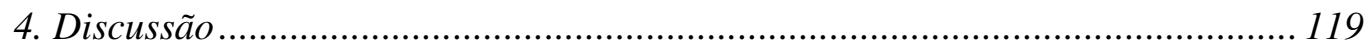

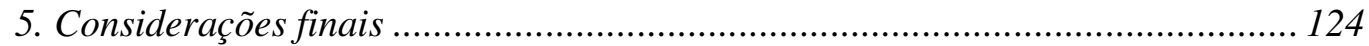

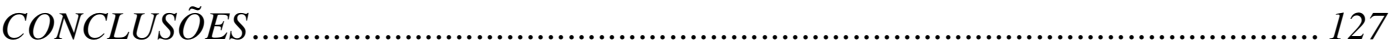

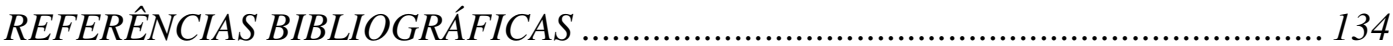




\section{INTRODUÇÃO}

A legislação antitruste brasileira vem a dar concretude a alguns dos princípios constitucionais que conformam a ordem econômica, tais como a livre-iniciativa, a livreconcorrência e a repressão ao abuso de poder econômico. Além de representar uma peça-chave do ambiente jurídico-institucional em que se desenvolve a atividade econômica nos mercados, sua aplicação exige a difícil tarefa de harmonização entre outros princípios e valores igualmente assegurados pela Constituição Federal de 1988.

Este trabalho analisa a disciplina jurídica da concorrência no Brasil, enfocando aspectos da lei n. ${ }^{o}$ 8.884/94 e da sua aplicação a respeito do controle da concentração econômica. Em se tratando de uma matéria que adquiriu eficácia em um período relativamente recente - embora estivesse presente no ordenamento jurídico nacional há algumas décadas - a operacionalização dessas regras, dotadas de abertura e flexibilidade, suscita curiosidade especialmente por representar uma inovação em relação às figuras jurídicas tradicionais.

No caso brasileiro, o arcabouço institucional estruturado nos anos 1990 para atender os problemas concorrenciais acompanhou as tendências mais contemporâneas seguidas pelas instituições dos países desenvolvidos. Este fato, para alguns, significou motivo de preocupação, levantando questionamentos sobre a viabilidade e conveniência de países em estágio menos avançado de desenvolvimento industrial adotarem instituições que, logo de início, tomassem uma forma que nos países desenvolvidos levara muito tempo para ser construída.

A análise das trajetórias nacionais de formulação e aplicação do direito concorrencial nos Estados Unidos, Europa e Japão, ao revelar que há diversidade de objetivos ou enfoques possíveis no manejo dessas regras - podendo variar, por exemplo, entre eficiência, inovação, competitividade, diluição do poder econômico, ampliação das oportunidades de negócio para os agentes no mercado, bem-estar do consumidor, distribuição de renda e desenvolvimento econômico, entre outros - reforça ainda mais a dúvida em relação às necessidades das economias em desenvolvimento. Será que adoção de modelos típicos de países desenvolvidos seria apropriada para um país como o Brasil, cujo processo de industrialização ainda não se completou? 
Para responder a essa questão, exigem-se mais do que um olhar voltado para a letra da lei de defesa da concorrência (Lei n. ${ }^{\circ}$ 8.884/94) e seu enquadramento no ordenamento jurídico nacional: é preciso também investigar a sua interpretação e aplicação à luz das especificidades desta economia. Assumindo essa premissa, o presente trabalho tem por objetivo analisar os contornos do direito antitruste brasileiro suas características, seus principais objetivos e possíveis limites - a partir do exame de um caso concreto, representado pela indústria petroquímica.

A petroquímica nacional constitui um setor cujas deficiências em relação ao padrão internacional de competição - especialmente a estrutura empresarial pulverizada e o baixo grau de integração entre as firmas - não puderam ser solucionadas com a mudança do marco regulatório realizada na década de 1990 (abertura, privatizações, desregulação e liberalização, acompanhadas da promulgação da lei antitruste). Diante disso, a reestruturação das empresas tornou-se uma necessidade premente, um prérequisito para a própria permanência da atividade no país, ensejando, na última década, a submissão de um volume elevado de atos de concentração ao Sistema Brasileiro de Defesa da Concorrência (SBDC) ${ }^{1}$.

Estas são, em princípio, condições ideais para examinar se a aplicação da disciplina antitruste seria aberta e flexível o suficiente para facilitar, e não obstruir esse processo. Ou, em outras palavras, se seria possível, neste caso, confirmar os receios dos críticos às medidas liberalizantes em relação à aplicação estrita das legislações de defesa da concorrência poder dificultar a consolidação de alguns setores da indústria nos países em desenvolvimento, por considerarem excessivos ou abusivos determinados níveis de concentração econômica.

O trabalho está organizado em quatro capítulos, além desta seção introdutória e das conclusões. O primeiro capítulo apresenta uma abordagem histórica dos conceitos e práticas da defesa da concorrência nos países centrais, para em seguida introduzir o debate levantado nos anos 1990 a respeito do papel da disciplina antitruste nos países em desenvolvimento.

O segundo capítulo descreve aspectos gerais do direito da concorrência no Brasil. Abordam-se suas origens históricas, seu enquadramento entre os princípios da

\footnotetext{
${ }^{1}$ Embora utilize como insumos os derivados de petróleo, a indústria petroquímica não está sujeita à regulação por agência setorial (Agência Nacional de Petróleo - ANP). Desse modo, neste caso não se verifica o potencial conflito de competências entre duas instâncias reguladoras, vez que apenas o SBDC responde pela disciplina da concorrência no setor.
} 
ordem econômica constitucional, a evolução da legislação e os parâmetros consagrados no ordenamento jurídico nacional para a análise de atos de concentração econômica.

Retomando a questão sobre a adequação do modelo de disciplina antitruste à luz das especificidades de uma economia em desenvolvimento, na sequiência este trabalho investiga a aplicação do direito concorrencial no contexto especial da indústria petroquímica brasileira. Para tanto, o terceiro capítulo expõe as características gerais desse setor, como também as particularidades que marcam a sua organização no país. Em seguida, reconstitui-se a trajetória da atuação estatal nessa indústria, desde a sua formação até a introdução das reformas dos anos 1990, em que também se dá o fortalecimento do arcabouço jurídico-institucional voltado à preservação das condições de concorrência.

O quarto capítulo trata dos principais rumos seguidos pelo processo de reorganização das empresas atuantes no setor petroquímico e examina a resposta dada pelas autoridades de defesa da concorrência. Ressaltam-se os critérios utilizados na análise dos atos de concentração e o caráter das decisões. Por fim, a última seção expõe as principais conclusões extraídas sobre os contornos da disciplina antitruste e a sua aplicação no Brasil, com base nas considerações sobre o caso concreto da petroquímica. 


\section{CAPÍTULO 1 - DIREITO DA CONCORRÊNCIA: CONCEITOS, PRÁTICAS E O CONTEXTO DOS PAÍSES EM DESENVOLVIMENTO}

Em linhas gerais, entende-se o direito da concorrência (ou antitruste) como um conjunto de regras e instituições voltadas a proteger a concorrência nos mercados de restrições ou eventuais distorções ${ }^{2}$. Em sua origem e evolução, encontram-se importantes transformações nos processos econômicos, as quais influenciaram o desenvolvimento de idéias, atitudes e valores em relação aos comportamentos nos mercados e ao papel que o Estado deveria desempenhar na economia.

Com efeito, contrariando o ideal liberal em relação ao absoluto virtuosismo do sistema de livre-mercado, a experiência da industrialização nos países centrais trouxe à tona, no século 19, a natureza verdadeiramente contraditória do alargamento dos mercados e do acirramento da concorrência. Se bem lograra impulsionar o progresso industrial e tecnológico, ampliar a oferta de bens e serviços, as opções dos consumidores e o bem-estar - a tal ponto de ter sido elevada à condição de Prometeu - a disputa por mercados, por outro lado, tinha vencedores, o que levou à formação e consolidação de estruturas empresariais centralizadoras de poder econômico, capazes de engendrar práticas abusivas, ocasionar conflitos de interesses e instabilidade social.

A disciplina jurídica da concorrência surgiu no fim do século 19, nos Estados Unidos, como uma das respostas a essa problemática, pretendendo corrigir algumas das imperfeições do liberalismo econômico e assegurar a igualdade de oportunidades no mercado para que as pequenas empresas pudessem concorrer. Esse caráter "corretivo" do funcionamento do mercado, com vistas a garantir os efeitos benéficos da competição, receberia expressão legal através de um arranjo de normas (as leis antitruste, como o Sherman Act, de 1890) que estabeleceriam a moldura dentro da qual os comportamentos nos mercados poderiam transcorrer livremente. Ao Estado caberia controlar a atividade nos mercados, intervindo diretamente nos processos competitivos

\footnotetext{
2 D. J. GERBER, Law and Competition in Twentieth Century Europe: Protecting Prometheus, Oxford, Oxford University Press, $2^{\text {a }}$ ed., 2003 [orig. 1997], introdução. Ou, segundo I. VAZ, o direito antitruste constitui o conjunto de regras e instituições destinadas a apurar e reprimir as diferentes formas de abuso de poder econômico e a promover a defesa da livre-concorrência. Direito Econômico da Concorrência, Rio de Janeiro, Forense, 1993, p. 243.
} 
apenas residual e pontualmente, para evitar ou reprimir eventuais efeitos perversos ou abusivos, e restabelecer as condições de livre-mercado.

Embora nas primeiras décadas do século 20 tenham surgido legislações de concorrência em outros países, como na Alemanha, é importante notar que a generalização da presunção em favor da concorrência e da idéia de que suas virtudes deveriam ser corporificadas em proteção jurídica específica é um fenômeno relativamente recente. Na Europa e no Japão ela se difunde somente após a $2^{\mathrm{a}}$ guerra mundial, ganhando proeminência a partir da década de $1970^{3}$.

Mesmo havendo um fundamento comum nessas legislações, a proteção da concorrência acabou sofrendo adaptações às características econômicas, idéias e valores dominantes em cada região. Assim, diferentemente do sistema norte-americano, em que a concorrência foi historicamente concebida como um fim em si mesma, nos modelos europeu e japonês ela receberia valor instrumental à consecução de outros objetivos sociais relevantes, como o desenvolvimento industrial e tecnológico, a integração econômica e o combate à inflação, entre outros.

No Brasil e demais países em desenvolvimento, o direito da concorrência assume destaque nos anos 1990, no contexto das reformas liberalizantes. Com suporte dos organismos internacionais, países que não dispunham de instituições para lidar com a matéria passaram a adotá-las. Em outros casos, como o brasileiro, o arcabouço jurídico passaria por uma revitalização, adequando-se às novas exigências impostas pelos processos de abertura, privatização e desregulamentação dos mercados internos, e à onda de fusões e aquisições então desencadeada.

Como sabido, a década de 1990 caracterizou-se pela presença de um forte discurso que absolutiza as virtudes do livre-mercado e da livre-concorrência. Nesse contexto, ganhou espaço o movimento de que haveria um modelo único de instituições capaz de satisfazer plenamente o bom funcionamento dos mercados, e que este deveria ser igualmente seguido por todos os países, mesmo que em diferentes estágios de desenvolvimento econômico ${ }^{4}$. No que se refere à defesa da concorrência, a despeito da variedade de enfoques experimentados pelos países com mais tradição na matéria (Estados Unidos, Europa, Japão) propagou-se a visão de que sua aplicação atenderia a uma função meramente corretiva de falhas de mercado, cujos limites viriam sinalizados

\footnotetext{
3 Idem

${ }^{4}$ H. J. CHANG, Kicking Away the Ladder - Development Strategy in Historical Perspective, Londres, Anthem Press, 2002.
} 
prioritariamente pelos critérios de eficiência e bem-estar extraídos do modelo idealizado de concorrência perfeita.

Essas proposições suscitaram reações sob diferentes ângulos. Entre os economistas, alguns apontaram para as limitações que um excessivo estreitamento da política de concorrência com o referencial neoclássico poderia ocasionar, ressaltando a importância dos países em desenvolvimento manterem, em sintonia com suas políticas antitruste, outros instrumentos de política voltados a estimular as empresas nacionais a ampliarem as condições de competição em âmbito internacional (política industrial ${ }^{5}$ ).

Entre os juristas, as discussões voltaram-se predominantemente aos objetivos do direito concorrencial (se um ou mais objetivos e qual/quais). Neste caso, as principais críticas focalizaram o radicalismo da instrumentalização do direito por conceitos e modelos econômicos (a chamada Análise Econômica do Direito), representada pelas teorias da Escola de Chicago $^{6}$, apontando que a aplicação das normas de defesa da concorrência deveria ser compatibilizada com outros valores que não exclusivamente a eficiência econômica.

Com o propósito de contextualizar e melhor caracterizar as divergências mencionadas, o presente capítulo explora os principais conceitos e práticas que marcam o direito da concorrência. Primeiramente, abordam-se algumas noções da teoria econômica fundamentais à compreensão dos parâmetros que orientam a formulação e aplicação das legislações antitruste. Na seqüência, serão tratadas as peculiaridades das regras jurídicas formatadas para disciplinar a competição, assim como algumas experiências internacionais paradigmáticas nessa área. Por fim, retoma-se a perspectiva dos países em desenvolvimento e o debate existente sobre o modelo de disciplina antitruste adequado às especificidades de suas economias.

\footnotetext{
${ }^{5}$ Neste trabalho, o termo política industrial será empregado como correspondente ao "conjunto de ações deliberadas de coordenação e orientação das atividades empresariais, visando melhorar o desempenho das firmas em seu conjunto (competitividade privada)". Cf. E. M. M. FARINA \& P. F. AZEVEDO, Política Industrial e Defesa da Concorrência: Considerações sobre a Experiência Brasileira nos Anos 1990, in Revista da Associação Nacional de Centros de Pós-Graduação em Economia - ANPEC, v. 2, n. 2, jul/dez (2001), p. 516.

${ }^{6}$ Para R. Posner, um dos principais expositores desta escola, quando as condições idealizadas de mercado não estivessem presentes, o direito ficaria a cargo de promover a eficiência, "mimetizando o mercado". Cf. J. COLEMAN, Economics and The Law: A Critical Review of The Foundations of The Economic Approach to Law, in Ethics, vol. 94, n. 4, jul-(1984), pp. 649-679. "When the market breaks down, the law should produce the result the market would have", p. 658. Nesta perspectiva, a Análise Econômica do Direito compreenderia duas dimensões: uma analítica, preocupada em demonstrar a possibilidade de explicação de algumas áreas do direito sob a ótica econômica da alocação eficiente de recursos; e outra normativa, preocupada em oferecer um referencial para legisladores e juízes decidirem casos de forma a promover a eficiência econômica.
} 


\section{A concorrência como objeto de disciplina jurídica: bases econômicas}

Embora não exista consenso na literatura econômica sobre a conceituação da concorrência e até que ponto ela pode ser tomada como a principal explicação para os comportamentos nos mercados, é natural supor que as legislações desenhadas para regular esse fenômeno, assim como a sua aplicação, tomem como referência as concepções dominantes para um dado momento histórico. Nesse sentido, pode-se dizer que no cerne das políticas de concorrência residem conceitos fundamentais da teoria micro-econômica ortodoxa, tais como as noções de concorrência perfeita, monopólio, equilíbrio e eficiência.

Sob o ângulo da teoria microeconômica neoclássica, a concorrência é usualmente tomada como o mecanismo de ajuste do sistema de mercado, cujo funcionamento atingiria a sua forma plena mediante as condições idealizadas de equilíbrio entre oferta e demanda ${ }^{7}$.

Subjacente a essa construção teórica há algumas suposições importantes sobre o comportamento humano e o funcionamento do mercado. A primeira delas diz respeito à racionalidade maximizadora e egoísta que conduziria a ação econômica dos indivíduos. A segunda refere-se à crença de que o sistema de preços conteria toda a informação necessária para que cada agente pudesse fazer suas escolhas de maneira independente com relação aos demais e de forma a maximizar seus interesses. Nesses termos, o comportamento individual racional dos agentes automaticamente conduziria ao bemestar coletivo, assim compreendido seguindo o critério de Pareto.

O chamado "ótimo de Pareto" corresponderia a um estado em que um indivíduo melhoraria sua situação sem piorar a dos demais, ao mesmo tempo em que fosse inexistente qualquer outra situação capaz de melhorar a condição de algum indivíduo sem piorar a de outro. Mediante um conjunto de condições, a livre-concorrência permitiria que o funcionamento livre do mercado (para Adam Smith, a "mão invisível”) produzisse esse resultado, proporcionando, de tal modo, o grau máximo de benefício para a coletividade ${ }^{8}$, consubstanciado na geração de eficiências.

\footnotetext{
${ }^{7}$ Cf. M. L. POSSAS et. al., Política Antitruste: Um Enfoque Schumpeteriano, in Ensaios sobre Economia e Direito da Concorrência, São Paulo, Singular, 2002, p. 12.

${ }^{8}$ Idem.
} 
O funcionamento eficiente do mercado englobaria considerações de três ordens. Segundo M. L. Possas et alii. ${ }^{9}$, a eficiência alocativa tem relação unívoca com o equilíbrio competitivo e é atingida quando ocorre a igualdade entre preço e custo marginal de produção. Nessa situação, o maior número de transações possíveis está sendo realizado e o maior excedente gerado. A eficiência distributiva, por sua vez, refere-se à distribuição "justa" do excedente entre produtores e consumidores, ao passo que a eficiência produtiva descreve a situação em que a firma está sendo operada de maneira a maximizar o rendimento e minimizar o custo de produção.

Em uma situação de equilíbrio competitivo (ou de concorrência perfeita) os três objetivos estariam sendo alcançados. Consideram-se centrais da configuração de mercados perfeitamente competitivos os seguintes elementos ${ }^{10}$ : a) existência de uma pluralidade de consumidores e produtores (estrutura de mercado atomizada), de tal forma que nenhum deles seja capaz de, isoladamente, influenciar os preços no mercado (tomadores de preços); b) existência de informação plena e perfeita sobre as condições de mercado; c) produtos homogêneos; e d) livre mobilidade dos fatores de produção.

Decorrem destes delineamentos duas dimensões complementares envolvendo a conceituação da concorrência ${ }^{11}$. A primeira refere-se à sua identificação como um mecanismo de ajustamento de cada agente à presença de outros competidores no mercado, em que se eliminam lucros extraordinários e o nível de produção dos bens é conduzido ao equilíbrio. A segunda diz respeito à visualização da competição como um estado hipotético, no qual a ação desse mecanismo de ajuste entre os agentes seria plena, e o poder econômico inexistente ${ }^{12}$.

Neste marco analítico, vale ressaltar a particular caracterização do papel que assumem os atores econômicos. Em primeiro lugar, destaca-se a homogeneidade entre eles como fator determinante do caráter passivo que assumem em relação às condições de mercado (uma vez que meros tomadores de preços). Além disso, e como reflexo da homogeneização dos concorrentes, sobressai o fato de que a competição se dá essencialmente em preços (e não em outras dimensões, como produto, qualidade,

\footnotetext{
${ }^{9}$ Idem.

${ }^{10}$ Idem, p. 13.

${ }^{11}$ Idem.

12 Estando a atuação do agente limitada à necessidade de adaptação a fim de restabelecer o equilíbrio competitivo no mercado, surge a crítica feita por diversos autores acerca da ausência de rivalidade do modelo de concorrência perfeita o que, na prática, resultaria na própria ausência de competição. Ver de F. A. HAYEK, The Meaning of Competition, in Individualism and Economic Order, Chicago, University of Chicago, 1980, p. 96, e J. A. SCHUMPETER, Capitalismo, Socialismo e Democracia, Rio de Janeiro, Fundo de Cultura, 1961[ed. Orig. 1942], parte II.
} 
design, etc), o que, em condições ideais, resulta na melhor forma de alocação dos recursos nos mercados e, por conseguinte, também de bem-estar social.

A situação antagônica à da plena concorrência corresponderia ao modelo de monopólio "puro", o qual contaria com a característica principal de existência de um único produtor, em condições de exercer influência sobre os preços e escolher o nível de produção que maximiza seus lucros, resultando ineficiente do ponto de vista social.

Da representação teórica das condições diametralmente opostas de concorrência perfeita e monopólio, como também dos resultados gerados, nos dois casos, em termos de alocação de recursos e bem-estar, extraem-se as principais proposições que fundamentam as políticas antitruste. Por um lado, a idéia de que, em condições ideais, a livre-concorrência constitui a instância de alocação de recursos que proporciona a máxima satisfação da coletividade, razão pela qual deve ser preservada. Por outro lado, constatada a possibilidade de haver desvios nesse padrão ideal, à medida que os mercados reais se aproximem da configuração monopolista, admite-se a necessidade de atuação do Estado, embora restrita à aplicação de medidas voltadas a restabelecer o equilíbrio competitivo. Admitindo-se, contudo, as limitações do próprio modelo e a complexidade do mundo real, constituem alvos centrais das leis concorrenciais os monopólios e, principalmente, os mercados organizados sob a forma de oligopólios.

De acordo com M. L. Possas, dentro dessa moldura teórica, cabe à disciplina jurídica

procurar evitar que a presença de (i) barreiras à entrada, (ii) tendências à concentração das participações dos agentes nos mercados e (iii) oportunidades de ações discricionárias a partir das quais as firmas possam restringir as margens de escolha dos consumidores ou a ação dos concorrentes repercuta negativamente sobre a eficiência técnica/alocativa ou permita aos produtores elevar preços e margens de lucro em detrimento do bem-estar dos consumidores ${ }^{13}$

Em função desses objetivos gerais, as preocupações das autoridades de defesa da concorrência focalizam as condutas e estruturas de mercado. No primeiro caso, procuram obstar tanto as práticas restritivas envolvendo relações horizontais - assim consideradas as ações dos agentes econômicos que reduzem a intensidade da concorrência afetando as relações entre empresas que atuam em um mesmo mercado de

\footnotetext{
${ }^{13}$ Cf. M. L. POSSAS et alii, Política Antitruste...op. cit., p. 13 e 14.
} 
bens ou serviços, tais como acordos de preços, a cooperação entre concorrentes e a construção de barreiras à entrada - como também as práticas restritivas verticais. Estas últimas abrangem as condutas que restringem a competição entre agentes que se relacionam como compradores e vendedores ao longo de uma cadeia produtiva ou em mercados finais, incluindo comportamentos como a discriminação e a fixação de $\operatorname{preços}^{14}$.

O controle das estruturas de mercado, por sua vez, pretende inibir a formação de estruturas excessivamente concentradas, tidas como geradoras de poder de mercado e como responsáveis pelo aumento do potencial de práticas abusivas, por se aproximarem às condições representadas no modelo de monopólio. Nesse caso, as autoridades de defesa da concorrência exercem o controle das operações empresariais como fusões, aquisições e conglomeração, podendo impor-lhes restrições ou determinar o desmembramento de empresas quando considerado o risco ou a prática de excercício abusivo do poder econômico nos mercados.

Pode-se dizer, portanto, que a noção de concorrência perfeita é uma referência importante para a disciplina antitruste, o que não significa que se pretenda introduzir estruturas de mercado atomizadas em todas as situações concretas analisadas (algo que não seria nem razoável, nem socialmente desejável, pois acarretaria custos e incertezas). Segundo P. Areeda et alii, o mercado perfeitamente competitivo é o resultado principal que o direito pretende atingir, mas que, na prática, acaba sendo relativizado em função: a) da complexidade dos mercados (e excluída desse modelo) representada pela existência de economias de escala, barreiras à entrada, custos de transação, assimetrias de informação e diferenciação de produtos, entre outros elementos; b) de fatores políticos e; c) em alguns casos, de preocupações sociais.

Assim, mais do que a estrutura atomizada propriamente dita, como único sinalizador do grau de competição, o modelo fornece um dos valores que orienta a aplicação da disciplina da concorrência: a noção de eficiência ${ }^{15}$. A influência e o peso relativo desse e de outros valores na apreciação dos casos concretos e que, em última análise, explicitam os objetivos da política antitruste, guardam necessária relação com as visões predominantes sobre os processos econômicos e o papel do Estado.

As legislações, por sua vez, foram desenhadas de tal modo a permitir aos intérpretes responderem a essas mudanças: a presença de disposições genéricas

\footnotetext{
${ }^{14}$ Idem.

15 Antitrust Analysis - Problems, Texts, Cases, $4^{\mathrm{a}}$ ed., Boston, Little Brown and Co.,1988, p. 10.
} 
possibilita, historicamente, a disputa em torno dos objetivos a serem perseguidos, dos valores e interesses a serem protegidos e, em suma, dos próprios conteúdos das normas. Desse modo, em perspectiva histórica, a trajetória da regulação da concorrência em diferentes sociedades revela momentos alternados de maior e menor vigor em sua aplicação. Além disso, modificam-se as justificativas aceitas para que eventuais restrições à competição sejam ou não sancionadas. Não há, portanto, um ponto preciso entre legalidade e ilegalidade nesse campo ${ }^{16}$, prevalecendo o critério da razoabilidade como método decisório. Sobre estas particularidades dos instrumentos jurídicos formatados para disciplinar a concorrência concentra-se o tópico a seguir.

\section{2. $\mathrm{O}$ direito para proteger a concorrência: abertura e flexibilidade}

Pelo fato de se voltarem para um objeto de natureza complexa, as normas de direito da concorrência assumem uma formatação especial. As diferentes legislações em matéria antitruste possuem a característica comum de incorporarem em seu texto dispositivos que lhes asseguram abertura e flexibilidade, permitindo que sua interpretação/aplicação seja moldada em relação à realidade mutável que disciplinam, para cada caso concreto ${ }^{17}$.

A exigência de flexibilidade no tratamento de questões concorrenciais, como nota A. M. Nusdeo, advém da

necessidade de avaliação de situações complexas, muito díspares e de difícil generalização, bem como de compreensão da estrutura e do funcionamento de diferentes mercados, e, ainda, [d]a atenção a ser dada a diversos princípios jurídicos no momento da aplicação das normas ${ }^{18}$

\footnotetext{
${ }^{16}$ Idem.

${ }^{17}$ P. A. FORGIONI usa a expressão "válvulas de escape" para denominar essa abertura e flexibilidade das normas de defesa da concorrência. "As legislações antitruste, quer no enunciado de suas normas, quer em seu processo de aplicação, contêm instrumentos destinados a evitar que a tutela da livre concorrência venha a desempenhar uma função oposta àquela desejada, criando, por exemplo, obstáculos ao crescimento da indústria nacional, ao aumento de seu grau de competitividade ou ainda à distribuição dos bens e serviços", p. 178. Segundo a autora, as "válvulas de escape" corresponderiam a: a) a regra da razão; b) o conceito de mercado relevante e c) a definição dos interesses protegidos. Os Fundamentos do Antitruste, São Paulo, RT, 1998, pp. 178-266.

${ }^{18}$ Cf. A. M. O. NUSDEO, Defesa da Concorrência e Globalização Econômica - O Controle da Concentração de Empresas, São Paulo, Malheiros, 2002, p. 66.
} 
Por conta disso, ao invés de definições dogmáticas, os textos legais incorporam expressões abertas - tais como "restrição à concorrência", "abuso de poder econômico", "tentativa de monopolização" e "posição dominante", entre outras - cujo sentido será precisado pelo intérprete, permitindo-lhe uma margem relativamente ampla para subsumir os fatos às hipóteses de incidência legal.

Mais do que no caráter genérico dos preceitos contidos na lei, a abertura das normas pode ser visualizada no método estabelecido para análise e sancionamento das práticas ou figuras típicas que são objeto de preocupação do antitruste. A origem desse recurso de flexibilidade remonta ao conceito de "regra da razão" (rule of reason) construído no ordenamento jurídico norte-americano.

Em princípio, a primeira lei antitruste promulgada nos EUA, o Sherman Act de 1890, embora adotasse prescrição genérica sobre práticas anticompetitivas ${ }^{19}$, não dispunha de qualquer mecanismo que possibilitasse a sua flexibilização em relação aos casos concretos, sendo então tomada em bases literais. A redação confusa, entretanto, gerava insegurança jurídica e dificultava a sua aplicação, de tal sorte que gradualmente a Suprema Corte passou a reconhecer que não "todo e qualquer contrato" seria objeto de preocupação das autoridades antitruste, mas somente aqueles que acarretassem restrições ao comércio consideradas desarrazoadas. Mais recentemente, afirma $\mathrm{C}$. Salomão Filho, essa concepção evoluiu: o requisito para que a restrição à concorrência seja sancionada, tanto em matéria de condutas como de estruturas é que, ao invés de desarrazoada, seja substancial e injustificada. Incluem-se, portanto, aspectos quantitativos e também de fundo ${ }^{20}$.

No caso norte-americano, aponta A. M. Nusdeo, a aplicação da regra da razão esteve sempre condicionada pela análise econômica. Desse modo, a definição das situações aceitas em caso de restrições à concorrência não incorporavam a consideração de outros objetivos sociais e políticos que não diretamente vinculados à proteção dos mercados e da competição ${ }^{21}$.

No Brasil, a legislação de defesa da concorrência faz uso dos chamados "conceitos jurídicos indeterminados" para dispor de flexibilidade na sua aplicação. Trata-se de conceitos cujos termos são vagos ou imprecisos, exigindo do intérprete que

\footnotetext{
${ }^{19}$ A seção 1 estabelece a ilicitude de todo e qualquer contrato, combinação na forma de truste ou qualquer outra forma, ou conspiração em restrição ao tráfico ou comércio entre os Estado, ou entre esses e naçães estrangeiras". Idem, p. 66.

${ }^{20}$ C. SALOMÃO FILHO, Direito Concorrencial - As Estruturas, $2^{\mathrm{a}}$ ed., São Paulo, Malheiros, 2002, p. 143.

${ }^{21}$ Cf. A. M. O. NUSDEO, Defesa da Concorrência...op.cit., p. 67.
} 
os complete, com base em dados extraídos da realidade ${ }^{22}$. Nesse sentido, destacam-se as expressões utilizadas na Lei de defesa da Concorrência (8.884/94) em seu artigo 20, tais como "domínio de mercado", "mercado relevante", "aumento arbitrário de lucros", "abuso de posição dominante", e também no artigo 54, em que estão presentes as expressões "eficiência", “desenvolvimento tecnológico", "desenvolvimento econômico", "motivo preponderante da economia nacional", e "bem comum"23.

No que se refere à disciplina dos atos de concentração, a legislação brasileira assegura uma certa margem de interpretação às autoridades para o exame do caso concreto, possibilitando ponderar eventuais proibições e aceitar algumas defesas quando haja prejuízo potencial ou efetivo à concorrência. Sendo assim, conforme o art. 54 da lei 8.884/94, o intérprete terá de considerar, primeiramente, se o ato de concentração em análise tem o potencial de restringir ou prejudicar a concorrência, ou resultar em dominação de mercados relevantes ${ }^{24}$. Em caso afirmativo, deverá se certificar de que o ato atende aos requisitos previstos nos $\S \S 1^{\circ}$ e $2^{\circ}$ para que seja aprovado. Não basta, entretanto, que a eventual restrição à concorrência advinda do ato seja justificável para a sua aprovação, mas devem ser atendidas as condições previstas no texto legal para que tal se verifique ${ }^{25}$.

A análise dos comportamentos dos agentes econômicos, por sua vez, tem sido realizada no sistema brasileiro em sintonia com a regra da razão desenhada no modelo norte-americano, no sentido de ponderar os efeitos das práticas em termos de bem-estar e condená-las somente se os prejuízos à concorrência não forem justificados. É o que se depreende da leitura do Anexo I da Resolução nº 20/1999 do CADE, referindo-se às práticas restritivas verticais e horizontais:

Em geral, tais práticas pressupõem a existência ou a busca de poder de mercado sobre o mercado relevante. Em diferentes graus, algumas podem também gerar efeitos em termos de bem-

\footnotetext{
${ }^{22}$ Ver a respeito da definição de conceito jurídico indeterminado, E. R. GRAU, Direito, Conceitos $e$ Normas Jurídicas, RT, 1988.

${ }^{23}$ Cf. A. M. O. NUSDEO, Defesa da Concorrência...op. cit., p. 70.

${ }^{24}$ Segundo observa P. A. FORGIONI, a própria delimitação do mercado de bens e serviços no qual se estabelece a concorrência, o mercado relevante, para que a partir dele se possam avaliar os efeitos das práticas para a apreciação de uma questão concorrencial constitui um dispositivo flexibilizador da aplicação da disciplina antitruste (denominado pela autora como "válvula de escape"). Isso porque os ordenamentos sugerem critérios para sua caracterização, mas não regras rígidas, o que na prática permite a discussão caso a caso, e a possível desconsideração de prejuízos à competição. Os Fundamentos do...op. cit., pp. 199-218. Ver descrição mais detalhada sobre o conceito de mercado relevante no próximo capítulo.

${ }^{25}$ Cf. A. M. O. NUSDEO, Defesa da Concorrência...op. cit., p.71
} 
estar ao mercado ('eficiências econômicas'), recomendando a aplicação do 'princípio da razoabilidade'. Desse modo, é preciso ponderar tais efeitos vis-à-vis os potenciais impactos anticompetitivos da conduta. Portanto, uma prática restritiva somente poderá gerar eficiências líquidas caso as eficiências econômicas dela derivadas compensem seus efeitos anticompetitivos.

É importante observar que a relativização do formalismo, em favor dos atributos da abertura e flexibilidade, é justamente o que permite a instrumentalização do direito da concorrência, explicitando, por sua vez, a dimensão política contida no seu direcionamento $^{26}$. Com efeito, em cada ordenamento jurídico, o grau de flexibilização introduzido pela previsão de justificativas possíveis para as restrições na concorrência permite entrever, na decisão de cada caso concreto, quais objetivos são efetivamente atribuídos à disciplina concorrencial e quais os interesses protegidos por meio dela.

Assim, há ordenamentos em que, à distinção do sistema norte-americano, a abertura das normas de concorrência pendeu à incorporação de objetivos outros que não estritamente concorrenciais, tais como promover o desenvolvimento tecnológico e industrial, a integração econômica, combater a inflação e gerar empregos, entre outros ${ }^{27}$. São exemplos nessa direção os sistemas europeu, japonês e coreano. Vale notar, entretanto, que o influxo de objetivos de outra ordem se apóia menos no texto da lei (visto que em geral contempla terminologia aberta) e mais no caráter e tendência da sua interpretação pelas autoridades competentes. Nesse particular, é importante destacar, a linha interpretativa será influenciada não somente pelas características institucionais do órgão responsável (perfil dos seus dirigentes, órgão do governo ao qual estão ligados, etc), mas também pela existência de políticas públicas definidas - e efetivas - em torno daqueles objetivos ${ }^{28}$.

De acordo com G. B. Doern, esse aspecto político do direito concorrencial pode ser identificado a partir da forma como os seus objetivos recebem expressão legal em cada ordenamento, podendo aparecer de vários modos. $\mathrm{O}$ primeiro refere-se ao método escolhido para analisar e sancionar práticas anticompetitivas, o qual pode variar entre dois extremos: de um lado a ilegalidade per se de determinada conduta, desconsiderando-se seus efeitos e as intenções que a projetaram; e, de outro lado, a

\footnotetext{
${ }^{26}$ G. B. DOERN \& S. WILKIS (eds), Comparative Competition Policy...op. cit., introdução.

${ }^{27}$ M. MOTTA, Competition Policy - Theory and Practice, New York, Cambridge University Press, 2004.

${ }^{28}$ Cf. A. M. O. NUSDEO, Defesa da Concorrência...op.cit., p. 69.
} 
ponderação desses elementos, com recurso à regra da razão de que se tratou anteriormente.

O segundo aspecto diz respeito à amplitude e natureza de aspectos "extraconcorrenciais" (genericamente denominados de "cláusula do interesse público") expressamente permitidos e levados em consideração na tomada de decisões das autoridades antitruste ${ }^{29}$ como elemento que também lhe confere abertura. Exemplo disso está contido no preâmbulo do Tratado Europeu, que prevê a integração econômica e social no âmbito da União Européia como objetivo a ser perseguido pelas instituições nacionais de defesa da concorrência dos países-membros. Alguns critérios de caráter genérico que às vezes são contemplados nas legislações são a promoção de emprego, desenvolvimento econômico e regional, ganhos de competitividade, entre outros.

Por fim, um terceiro elemento que caracteriza o grau de abertura dos objetivos da política antitruste materializa-se na eventual previsão de setores ou atividades isentas da aplicação do direito antitruste. Embora, inicialmente, considere-se o direito da concorrência um mecanismo de regulação econômica de caráter horizontal, isto é, aplicável a todos os setores e atividades, na prática, esse aspecto acaba sendo flexibilizado em alguns ordenamentos (como na Europa, cuja legislação prevê um regime específico ao setor de comunicações, ou nos EUA, que conta com outras isenções para setores regulados por agências independentes). No caso brasileiro, a lei 8.884/94 não prevê expressamente a possibilidade de isenções.

Nesse sentido, em cada ordenamento jurídico o desenho particular da regra antitruste acaba assumindo maior ou menor grau de rigidez ou flexibilidade, delimitando, no primeiro caso, um regime jurídico mais estável e formalista (como nos Estados Unidos), ou, no segundo caso, conferindo maior abertura ao intérprete, de tal sorte a fortalecer o caráter de implementação de uma política pública, priorizando maior amplitude possível de objetivos políticos e sociais (caso Europeu, Japonês e Coreano, por exemplo) $)^{30}$.

\footnotetext{
${ }^{29}$ G. B. DOERN \& S. WILKIS (eds), Comparative Competition Policy...op. cit., p. 17.

${ }^{30}$ D. J. GERBER, Law and Competition...op. cit., p. 12.
} 


\section{As experiências internacionais de política de concorrência e controle das estruturas de mercado}

Um olhar sobre as práticas da disciplina concorrencial nos diferentes países, em perspectiva histórica, reforça a percepção de que a despeito de um fundamento comum, subsistem diferenças na forma como as instituições nacionais de defesa da concorrência percebem, formulam e aplicam o direito concorrencial. E essa variedade está relacionada com os objetivos de política que se pretende priorizar. Diante disso, a caracterização da política antitruste, em cada país, deve ser tratada como inserida em diferentes contextos sociais, políticos, jurídicos e econômicos que não podem ser desconsiderados $^{31}$. A seguir são apresentadas algumas experiências na matéria.

\subsection{Nos Estados Unidos: da concorrência atomística à eficiência de mercado}

No ordenamento jurídico norte-americano, onde a legislação antitruste teve origem, a concorrência é valorada como um fim em si mesmo. Como resultado, sua aplicação esteve historicamente atrelada ao combate das estruturas centralizadoras de poder de mercado, vinculando-se, assim, mais estreitamente com o paradigma ideal da concorrência perfeita. Progressivamente foi ganhando espaço o argumento da busca de eficiências (em sentido estático) como objetivo legítimo central à disciplina concorrencial, o que acabou por flexibilizar a postura contrária às estruturas econômicas mais concentradas.

$\mathrm{O}$ arcabouço legal que trata da matéria antitruste foi inaugurado nos EUA com a promulgação do Sherman Act, em 1890, prevendo penalidades de natureza criminal para aqueles que a violassem, como prisão e multa. Esse documento contém duas seções importantes: a primeira estabelece a regra genérica de coibição de "qualquer acordo ou contrato que possa restringir o comércio"; e a segunda proíbe a "monopolização" (i. e., dominação dos mercados) ou a sua tentativa. Inicialmente, portanto, não havia previsão expressa acerca do controle da concentração econômica, de modo que ela só poderia ser alvo de sanção se resultasse de alguma das práticas previstas nas seções um e dois da Lei.

\footnotetext{
31 Será conferida maior atenção à evolução norte-americana, pelo fato de servir de inspiração mais evidente ao modelo brasileiro do controle de concentrações que mais adiante será analisado.
} 
Entretanto, o excessivo grau de generalidade do texto legal dava muita margem para questionamentos. Na prática, nos primeiros anos de vigência da lei a sua interpretação pela Suprema Corte tendia, inicialmente, a beneficiar as empresas ${ }^{32}$. A primeira decisão em que houve condenação ocorreu em 1897, quando o truste de dezoito empresas ferroviárias (Trans Missouri Freight Association) foi penalizado em virtude da ilegalidade do acordo de preços praticado. Naquela ocasião, prevaleceu a interpretação de que com a promulgação da Lei Sherman o Congresso norte-americano pretendia declarar ilegais todos os acordos de preços, e que, portanto, não caberia aos juízes decidir quais desses acordos eram "razoáveis" e quais não ${ }^{33}$, fixando-se assim a ilegalidade per se daquela conduta. Alguns anos depois, condenou-se também a restrição de preços em relações verticais, estabelecendo-se a ilegalidade per se da fixação de preços de revenda ${ }^{34}$, fato que jamais seria revertido ${ }^{35}$.

Foi só a partir do caso Standard Oil, em 1911, que a Suprema Corte decidiu que, tendo em vista que todas as transações econômicas resultavam em alguma forma de restrição ao comércio, seria estabelecida uma "regra da razão" para determinar se uma prática específica seria considerada ilegal perante o Sherman Act. Naquele contexto, as operações que não tivessem o propósito explícito de restringir a concorrência, mas produzissem esse resultado marginalmente, seriam permitidas, ao passo que aquelas que tivessem esse resultado como objetivo central seriam punidas ${ }^{36}$. A partir desse caso, como também do julgamento do American Tobacco - ambos resultando em condenações para as empresas que culminaram no seu fracionamento - a disciplina antitruste consolida sua força nos EUA e, principalmente, sua vinculação à noção de concorrência associada a estruturas econômicas atomizadas.

Alguns anos depois, sucessivas legislações viriam a completar e aprimorar o sistema antitruste norte-americano. Nestas, nota-se a tendência de especificar com maior clareza as práticas proibidas, criando regras per se que definem condutas como

32 G. G. PETERS, US Competition Policy Institutions, in G. B. DOERN \& S. WILKIS (eds), Comparative Competition Policy - National Institutions in a Global Market, Oxford, Claredon Press, 2001, p. 43 e ss.

${ }^{33}$ Cf. M. MOTTA, Competition Policy...op. cit., p. 4.

${ }^{34}$ Por meio da fixação de cláusula de revenda, os produtores obrigam varejistas a venderem seus produtos acima de um preço mínimo por eles estabelecidos.

${ }^{35}$ Cf. M. MOTTA, Competition Policy...op. cit, p. 4. A ilegalidade per se implica desconsideração de eventuais justificativas à determinada prática, considerando-se exclusivamente os efeitos práticos ou potenciais de dano à concorrência.

36 Mediante o recurso à regra da razão, as empresas poderiam procurar se defender da acusação de ilegalidade e tentar convencer a Corte de que seu comportamento não acarreta prejuízos ao bem-estar. Idem. 
contrárias à lei independentemente das suas razões e dos efeitos ${ }^{37}$. Em 1914, surge o Clayton Act e também há a criação do Federal Trade Comission (FTC), instituição administrativa competente para aplicar as normas de defesa da concorrência. Essa nova legislação viria a incluir expressamente ao âmbito de preocupações da disciplina antitruste a avaliação de operações de concentração entre empresas capazes de acarretar prejuízos à concorrência ${ }^{38}$.

Contudo, não somente nessa fase inicial, mas também em outros períodos mais recentes do direito concorrencial norte-americano, já era possível notar situações em que seus preceitos seriam relativizados, em virtude de questões de ordem política e econômica. Por exemplo, durante a Primeira Guerra, em que o liberalismo norteamericano cedeu espaço para uma espécie de "coalizão" entre o governo e as empresas como forma de coordenação da economia. Com a Grande Depressão dos anos 1930, esse viés se acentuou, marcando-se, assim, um período de flexibilização na aplicação das normas antitruste, que perdurou aproximadamente até a Segunda Guerra. Uma das decisões mais importantes dessa época foi tomada em 1933, no caso Apalachian Coals vs. US, que constituiu uma das poucas exceções à proibição per se da fixação de preços. Em 1940, diante das mudanças nas condições econômicas, a condenação per se foi restabelecida. Tais situações são bastante representativas do fato de que o direito antitruste e sua aplicação devem ser compreendidos em contextos políticos, econômicos e históricos determinados ${ }^{39}$.

Assim, entre as décadas de 1940 e 1970, a chamada "era de ouro do capitalismo", a política antitruste voltou a ser mais intensa e ativa, caracterizando-se mais pelo desejo de restringir o tamanho e poder das grandes firmas do que pelo objetivo de promover eficiência econômica, uma atitude condizente com o pensamento econômico dominante na época ${ }^{40}$. Nesse contexto, seria editado o Cellar-Kefauver Act de 1950, que viria a especificar em maior detalhe as ações que seriam consideradas anticompetitivas e estabelecer controle mais direto sobre atos de concentração econômica envolvendo empresas atuantes no mesmo mercado.

Sob forte influência das teorias de organização industrial com foco no paradigma "Estrutura-Conduta-Desempenho", ganha espaço o argumento da Escola de Harvard em

${ }^{37}$ Cf. G. G. PETERS, US Competition Policy..., op. cit, p. 45.

${ }^{38}$ Há registros de que a própria promulgação da Lei Sherman, com foco nas condutas empresariais anticompetitivas, teria estimulado a onda de fusões e aquisições que ocorreu nos EUA entre o final do século 19 e os primeiros anos do século 20. M. MOTTA, Competition Policy...op. cit, p. 5.

${ }^{39}$ Cf. M. MOTTA, Competition Policy...op. cit., p. 6.

${ }^{40}$ Idem, p. 7. 
defesa do controle estatal mais severo das estruturas empresariais. Enfatizam-se o virtuosismo das estruturas atomizadas e o caráter "anti-natural" da concentração de poder econômico e das barreiras à entrada ${ }^{41}$, como fundamento para uma aplicação mais severa da política antitruste, a fim de promover comportamentos que levassem à melhor performance no mercado.

$\mathrm{Na}$ tradição estruturalista de Harvard, a presença de estruturas concentradas em um dado mercado era considerada uma evidência praticamente inafastável da existência de concentração abusiva de poder econômico. Neste paradigma de política, não havia necessidade de prática colusiva direta para que se considerasse que a operação restringia o comércio (nos termos da Lei Sherman), bastando para tanto o comportamento de uma firma líder de mercado visando manter ou ampliar sua posição ${ }^{42}$. Nesse sentido, considerou-se no caso Alcoa, de 1945, a elevada participação de mercado da empresa como condição suficiente para a sua condenação. Em análise de operações de concentração, situações semelhantes podem ser observadas nos casos Brown Shoe Co., Inc. v. United States (1962), Philadelphia (1963) e Procter and Gamble (1967) ${ }^{43}$.

Durante essa fase, o tratamento conferido às estruturas de mercado pelas autoridades antitruste norte-americanas - direcionado à dispersão dos centros de poder econômico - demonstrava a busca de um ideal de mercado atomista, em sintonia com o modelo de concorrência perfeita, mas também refletia os valores da sociedade norteamericana e as estruturas de poder ali constituídas, no sentido de privilegiar a proteção às pequenas empresas em detrimento de outros objetivos de política, como por exemplo a redução dos custos de produção e dos preços aos consumidores.

Em 1976, os Estados Unidos aprovariam o Hart-Scott-Rodino Act, com vistas a fortalecer ainda mais esse controle das concentrações. Entre suas disposições mais importantes encontram-se a fixação do sistema de notificação prévia das operações à autoridade antitruste, pelo qual as empresas interessadas deveriam prestar informações sobre o caso e submetê-lo à análise das instituições de defesa da concorrência antes de efetivá-lo propriamente. Além disso, a nova legislação instituiu o controle administrativo de atos de concentração, até então de caráter judicial, o que resultou na

\footnotetext{
${ }^{41}$ Cf. O. BUDZINSKI, Pluralism of Competition Policy and the Call for Regulatory Diversity, 2003, acessível em http://papers.ssrn.com/sol3/papers.cfm?abstract_id452900 .

${ }^{42}$ Cf. G. G. PETERS, US Competition Policy..., op. cit, p. 49.

${ }^{43}$ Cf. M. MOTTA, Competition Policy...op. cit., p. 8.
} 
aproximação do sistema norte-americano ao europeu e aos demais que efetuam esse tipo de controle ${ }^{44}$.

Cumpre notar, ainda, que desde 1968, as agências antitruste federais publicavam documentos destinados a apresentar o sentido de sua interpretação às regras sobre atos de concentração - os Mergers Guidelines - para orientar os agentes empresariais, e que não dispõem de força normativa. As publicações que se sucederam são bastante representativas das mudanças de enfoque ocorridas no tratamento das concentrações. Assim, em 1968, as guidelines expressavam a importância de que o controle dos atos de concentração fosse exercido de modo a preservar estruturas competitivas. Definiam também o uso, pela Suprema Corte, do método de quantificação do grau de concentração do mercado que resultava da soma da porcentagem de participação das quatro maiores empresas no mercado (denominado CR4) ${ }^{45}$.

Ao final dos anos 1970 e início dos 1980, há uma importante mudança no enfoque atribuído à disciplina concorrencial, que afeta substancialmente o tratamento da concentração econômica. Observa-se que o estruturalismo de Harvard perde espaço para outra abordagem que enfatiza a eficiência econômica e o bem-estar do consumidor compreendidos no sentido particular atribuído pela teoria neoclássica - como justificativas aceitáveis para a tolerância da existência de estruturas mais concentradas.

Essa mudança reflete não apenas uma transformação nas concepções acerca do funcionamento dos mercados e da concorrência, mas também a difusão da idéia de que a indústria norte-americana necessitava de ajustes que lhe permitissem aumentar sua competitividade internacional o que, por sua vez, exigiria medidas de política específicas $^{46}$. Assim, a proposição neoclássica em torno da busca de eficiência nas operações econômicas é levada ao extremo, passando a constituir o único objetivo da política antitruste defendida pela Escola de Chicago, tendo em Robert Bork um de seus principais expoentes ${ }^{47}$. O caso que marca a mudança em direção à predominância dos argumentos de Chicago é o GTE-Sylvania (1977), em que a Suprema Corte decidiu que restrições verticais que não envolvessem preços deveriam ser submetidas à regra da razão ${ }^{48}$.

\footnotetext{
${ }^{44}$ Cf. A. M. O. NUSDEO, Defesa da Concorrência...op.cit., p. 87

${ }^{45}$ Idem.

${ }^{46}$ Idem, p. 95.

${ }^{47}$ The Antitrust Paradox, New York, Basic Books, 1978.

${ }^{48}$ Cf. M. MOTTA, Competition Policy...op. cit., p. 7.
} 
Na prática, sob a influência da Escola de Chicago, que se tornaria proeminente sobretudo durante a Era Reagan (1981-88), há novamente um certo relaxamento na preocupação com a excessiva concentração de poder econômico, argumentando-se que as próprias forças de mercado selecionariam as empresas mais eficientes, sendo assim desnecessária a intervenção das autoridades antitruste. Observa-se então uma forte queda no número de julgamentos envolvendo atos de concentração nos EUA.

Em linhas gerais, seguindo descrição de A. M. de C. Fontenele (citando Shepherd), essa orientação de política antitruste está apoiada nas seguintes hipóteses:

(i) O domínio de mercado é decorrente de eficiência superior, de maneira que níveis elevados de concentração podem ser aceitos e até estimulados;

(ii) Condutas de conluio devem ser evitadas (todavia, quando ocorrem, tendem a ser transitórias, posto que geradoras de conflitos); e

(iii) A busca de poder de monopólio (ao invés de eficiência) é fadada ao fracasso, pois exige ações de altos custos ${ }^{49}$.

O novo "tom" da disciplina concorrencial ganha expressão também nas diretrizes publicadas pelas autoridades antitruste norte-americanas, os guidelines. Os sucessivos documentos editados em 1982, 1984 e 1992 expõem o deslocamento da ênfase da concentração em si mesma, para a criação de poder de mercado, sendo este definido como a capacidade de determinar preços acima do nível competitivo, por um período de tempo significativo.

A partir de então, consolida-se a concepção até hoje preponderante de que a participação de mercado e o grau de concentração nele existente constituem apenas o ponto de partida para a consideração de problemas concorrenciais. As etapas seguintes à avaliação da concentração nos mercados são a consideração dos efeitos concorrenciais da operação em questão, a facilidade de entrada no mercado, a verificação de eficiências consideradas sob o ângulo microeconômico tradicional (cujo tratamento foi revisto em 1997) e, por fim, a análise da eventual presença de empresas ou divisões em crise ou dificuldades.

No período mais recente, argumentos de eficiência continuam tendo espaço importante na avaliação dos casos de defesa da concorrência, mas dividem a atenção

${ }^{49}$ A. M. de C. FONTENELE, Progresso e Método na História das Teorias da Organização Industrial, São Paulo, FEA-USP, 1995. (Tese de Doutoramento), p. 49. 
com outras questões, tais como o desenvolvimento tecnológico e os ganhos de competitividade externa das empresas. Permite-se, portanto, o crescimento dos agentes econômicos, em contraste com a percepção originária do antitruste norte-americano, segundo a qual se pretendia preservar as estruturas descentralizadas de poder econômico nos mercados, com vistas a promover outros valores sociais relevantes (como a proteção à sobrevivência das pequenas empresas, por exemplo). A doutrina econômica e a política antitruste nos Estados Unidos de hoje refletem essas idéias, em muitas situações conflitantes entre si, exigindo a sua solução uma resposta caso a caso, levando em conta os bens jurídicos predominantes em cada um deles ${ }^{50}$.

\subsection{O paradigma europeu e a idéia de "concorrência-instrumento"}

No caso europeu, a política de concorrência não apenas surge um pouco mais tarde do que nos EUA, como também se diferencia por enfeixar mais explicitamente uma pluralidade de objetivos não estritamente vinculados à "concorrência", além de estar articulada com outras políticas destinadas a promovê-los, como é o caso das políticas de fomento industrial e comercial, auxílio às pequenas e médias empresas, proteção ao meio-ambiente, e integração econômica ${ }^{51}$. Desse modo, a competição é valorada enquanto meio para atender outros objetivos relevantes, e não como um fim em si mesmo ${ }^{52}$.

Outra característica importante do direito concorrencial europeu diz respeito ao fato de existirem dois níveis de jurisdição: um nacional e outro supranacional, pertinente à União Européia. Nos dois casos, segundo Wilks et alii, os objetivos que originaram a criação dessas normas e influenciam a orientação de sua aplicação são variados, incluindo o controle de grandes empresas, a promoção do livre-mercado, a busca de competitividade internacional, e proteção do consumidor e, particularmente no âmbito supra-nacional, o objetivo proeminente tem sido consolidar a integração entre as nações européias.

\footnotetext{
${ }^{50}$ Idem, p. 97. Além disso, uma tendência importante a se destacar na fase atual é a renovação do combate aos cartéis, que tem crescido em relevância e agressividade, facilitada, entre outras razões, pela implementação da política de leniência.

${ }^{51}$ Cf. M. MOTTA, Competition Policy...op. cit., p. 9.

52 No âmbito da UE, por exemplo, a concorrência é um instrumento para atingir-se o fim maior perseguido pela própria União, maior competitividade internacional e integração entre os paísesmembros. Cf. P. A. FORGIONI, Os Fundamentos do Antitruste...op. cit., p. 164.
} 
Uma das primeiras legislações européias voltadas à defesa da concorrência surge na Alemanha dos anos 1920, disciplinando a prática de cartéis. Naquele país, desde o final do século XIX, multiplicavam-se os acordos entre empresas atuantes nos mesmos mercados, inclusive com apoio do governo, pois eram vistos como instrumentos para controlar ou contornar a instabilidade econômica decorrente do acirramento da concorrência e das guerras de preços. $\mathrm{O}$ direito concorrencial alemão surge fortemente inspirado no princípio da liberdade econômica, constituindo a liberdade contratual um dos seus elementos centrais. Diante disso, a condenação de cartéis ocorria somente em situações extremadas, como quando existisse o risco de uma completa monopolização ou houvesse exploração abusiva dos consumidores.

A primeira legislação foi promulgada em 1923, em um contexto específico de hiper-inflação e, como reflexo daquela concepção de liberdade econômica, não proibia a realização de cartéis, mas apenas obrigava que fossem registrados junto a um órgão do governo para efeitos de controle ${ }^{53}$. Todavia, a partir dos anos 1930, durante a "Grande Depressão", tornou-se freqüente o envolvimento compulsório das empresas em cartéis, prática disseminada sobretudo durante o regime nazista. Nesse contexto, a idéia de permitir a coordenação entre empresas e a concentração entre elas com vistas a criar empresas mais fortes, os "national champions" era bem aceita ${ }^{54}$. Refletindo essa concepção, a legislação antitruste da Alemanha Ocidental continha diversas disposições para absolver práticas restritivas quando estivessem presentes determinadas circunstâncias consideradas mitigadoras dos eventuais efeitos perversos da concentração ${ }^{55}$.

A preocupação com a concentração excessiva do poder econômico só aparece expressa na legislação alemã após a $2^{\mathrm{a}}$ Guerra Mundial, por imposição das forças Aliadas. A justificativa para a adoção de uma lei antitruste era não apenas assegurar condições para promover o progresso econômico, mas principalmente desmembrar as estruturas concentradas de poder econômico, vistas como uma ameaça em potencial pelas nações que saíram vitoriosas da Guerra. Em 1957, após longo debate, a Alemanha aprovaria uma legislação antitruste mais estrita. Nota-se, entretanto, que essa política de desconcentração viria a ser interrompida alguns anos depois, quando os Estados Unidos

\footnotetext{
${ }^{53}$ Cf. M. MOTTA, Competition Policy...op. cit., p. 9 e ss.

${ }^{54}$ Idem.

${ }^{55}$ Cf. H. J. CHANG, The Economics and Politics of Regulation, in Cambridge Journal of Economics, 21 (1997), pp. 703-728.
} 
e a Grã-Bretanha passam a visualizar que o foco da ameaça econômica e geopolítica se deslocara para a União Soviética ${ }^{56}$.

No sistema alemão, os procedimentos para controle de operações de concentração econômica estão em vigor desde 1973 e são atendidos desde então, estabelecendo proibições ou eventuais modificações nas operações consideradas restritivas à concorrência. Vale notar, entretanto, que persiste a ênfase na liberdade econômica como diretriz para a aplicação do direito concorrencial, de modo que os atos de concentração são analisados na medida em que possam levar à formação de agentes dominantes que poderiam representar limitação à liberdade econômica de seus concorrentes $^{57}$.

$\mathrm{O}$ momento posterior à $2^{\mathrm{a}}$ Guerra Mundial marca a difusão das legislações de defesa da concorrência entre as nações européias, embora sua aplicação tenha levado algumas décadas para tornar-se mais rigorosa. Nesse ponto reside outra distinção importante em relação à política de concorrência norte-americana - e que reforça o caráter de política pública que está na base do antitruste - uma vez que entre 1945-70, período em que a Europa estava sendo reconstruída, após a guerra, foi dada menor ênfase à regulação, ao passo que nos EUA ela foi extremamente ativa.

O governo francês, por exemplo, especialmente nos anos 1960, explicitamente encorajou concentrações com base no argumento da necessidade de fortalecer as firmas francesas para que pudessem sobreviver à competição internacional, prevalecendo o uso de instrumentos de política industrial sobre a regulação da concorrência.

Na Grã-Bretanha, diferentemente, a legislação concorrencial adotada em 1948, o Monopolies and Restrictive Practices Act, surge com uma motivação particular, baseando-se na idéia de que a concorrência ajudaria a promover o pleno emprego. A partir de então, foram editadas sucessivas legislações complementando o sistema antitruste, sem, no entanto, especificar com clareza os seus objetivos, estabelecer penalidades para as hipóteses de descumprimento da lei, nem tampouco prever ferramentas apropriadas para a sua implementação, o que gerava freqüentes questionamentos sobre a efetividade do sistema. Por isso, em 1998, entra em vigor nova legislação de defesa da concorrência, desta vez mais alinhada com o modelo norteamericano.

\footnotetext{
${ }^{56}$ Cf. M. MOTTA, Competition Policy...op. cit., p. 10.

57 Sobre o direito concorrencial alemão, ver C. SALOMÃo FILHO, Direito Concorrencial - As Estruturas...op. cit., e O. BUDZNISKI, Pluralism of Competition Policy...op. cit.
} 
Em âmbito supranacional, por sua vez, a legislação de defesa da concorrência encontra sua origem mais remota no acordo firmado entre França, Alemanha, Itália e os países que integravam o Benelux em 1951, o Tratado de Paris. Naquela ocasião, os países pactuaram a proibição de barreiras comerciais, assim como práticas discriminatórias ou restritivas, capazes de distorcer a concorrência entre eles, que em 1957 viriam a constituir a base da Comunidade Econômica Européia, estabelecida por meio do Tratado de Roma $^{58}$. Este último dispõe sobre a disciplina básica da Comunidade Européia e do seu mercado comum, mas sua redação foi alterada pelo Ato Único Europeu, em 1986; pelo Tratado de Maastricht que estabelece a União Européia, em 1992; e também pelo Tratado de Amsterdã, em 1997, que resultou na renumeração dos artigos 59 .

Alguns dos princípios centrais da atual legislação concorrencial européia já estavam presentes no Tratado de Paris. Os artigos 65 e 66 - o primeiro contendo proibição de acordos e práticas concertadas entre firmas ou grupos de empresas que tendam direta ou indiretamente a restringir ou distorcer a concorrência no âmbito do mercado comum europeu; o segundo dispondo sobre o abuso de posição dominante empreendido por empresas que utilizam seu poder para perseguir objetivos contrários àqueles do Tratado - encontram correspondência com os dispositivos dos artigos 81 e 82, respectivamente, do Tratado de Roma.

A partir da constituição da Comunidade Econômica Européia, em 1957, firma-se a noção hoje corrente de que a concorrência serve como instrumento à integração entre as nações européias, passando, então, a sua disciplina jurídica a moldar-se a esse objetivo central. Em âmbito supranacional, o direito da concorrência europeu assumiria duas principais funções: de um lado, estimular práticas competitivas e eficientes por parte das empresas, com vistas a alavancar o crescimento econômico europeu e promover a integração; por outro lado, desestimular as práticas protecionistas das economias nacionais, capazes de obstruir o fluxo de comércio.

Com o advento da União Européia, a ênfase na integração econômica ganhou proeminência. Todavia, é importante destacar que assim como no plano interno aos países, em sede supranacional o direito antitruste passou a ser utilizado com uma pluralidade de objetivos. Especialmente, aponta a doutrina, à medida que avança o processo de integração abre-se a possibilidade de que outras diretrizes de política

\footnotetext{
${ }^{58}$ Idem, p. 13.

${ }^{59}$ Cf. A. M. O. NUSDEO, Defesa da Concorrência...op.cit., p. 97.
} 
ganhem mais espaço. Com efeito, entre os principais objetivos atribuídos ao direito concorrencial europeu - e freqüentemente em disputa - estão: a) a liberdade econômica (influência alemã); b) ideais sociais; c) justiça social e equidade; d) combate à inflação; e) progresso e desenvolvimento econômico (competitividade internacional) e; entre os menos reconhecidos, a promoção da eficiência econômica ${ }^{60}$.

Sobre esse aspecto - a menor ênfase no objetivo de promover eficiência econômica - o contraste com o sistema norte-americano seria resultado da existência de uma ligação mais direta do direito da concorrência com os objetivos de política econômica e industrial. Aponta nessa direção o enunciado do Tratado da Comunidade Econômica Européia, instituído pelo Ato Único Europeu de 1986, que estabelece expressamente (nos arts. 163 a 173) o estímulo à competitividade e a promoção de pesquisa e desenvolvimento como objetivos a serem incorporados ao direito antitruste europeu $^{61}$.

Como nota A. M. Nusdeo, a vinculação das normas de concorrência aos objetivos de política industrial não significa que a sua aplicação seja descuidada, mas sim que ela integra um conjunto mais amplo de políticas, com as quais estabelece comunicação direta. Em outras palavras, a concorrência e sua disciplina jurídica são vistas como ferramentas não apenas da integração econômica entre as nações européias - necessárias para impedir as práticas protecionistas que inibam esse processo - mas também para fortalecer as empresas européias e ampliar suas condições de competir no mercado mundial.

De acordo com H. J. Chang, a noção de concorrência subjacente a esse modelo é inspirada em autores como Marx, Schumpeter e Hayek, que concebem a existência de poder de mercado como uma conseqüência inevitável do jogo competitivo. Em função disso, a disciplina antitruste européia privilegia aspectos dinâmicos do comportamento dos agentes nos mercados, bem como a inovação e o desenvolvimento tecnológico ${ }^{62}$, de modo que a avaliação das eficiências e da eventual ilicitude das práticas empresariais incorpora outros critérios - tais como os ganhos em escala e objetivos de longo prazo que não exclusivamente de natureza estática e imediatista. Segundo o autor, a mesma abordagem inspira os sistemas japonês e coreano.

\footnotetext{
${ }^{60}$ Cf. D. J. GERBER, Law and Competition...op. cit, pp. 417-420.

${ }^{61}$ Cf. A. M. O. NUSDEO, Defesa da Concorrência..., p. 99.

${ }^{62}$ Cf. H. J. CHANG, The Economics and Politics of Regulation..., op. cit., p. 706.
} 
Essas características podem ser observadas nas principais normas comunitárias de defesa da concorrência, que estão presentes nos artigos 81 e 82 do Tratado de Roma, estabelecendo a proibição para as práticas concertadas aptas a restringir a concorrência e o abuso de posição dominante, prevendo, contudo, condições para a sua aprovação. Em 1962, o Regulamento do Conselho Europeu 17 viria a disciplinar de forma mais detalhada esses dispositivos, estabelecendo um sistema de isenções que poderia ser aplicado individualmente ou em bloco.

No que diz respeito ao controle de atos de concentração, este não faz parte expressamente das regras estabelecidas no Tratado de Roma. O tema só recebeu regulamentação em 1989, com a adoção do Regulamento 4064, após um intenso e prolongado debate que dividiu os países essencialmente em torno das concepções sobre o papel do direito da concorrência e sua relação com a política industrial. Nesse debate, Alemanha e Grã-Bretanha se posicionaram defendendo que o controle da concentração econômica deveria ocorrer sob bases exclusivamente concorrenciais - perspectiva esta que acabou prevalecendo - ao passo que a França desejava que fossem considerados critérios de política industrial, assim como questões sociais ${ }^{63}$.

\subsection{Japão e Coréia do Sul: articulação entre a defesa da concorrência e a política industrial}

No Japão, a legislação antitruste surge como inovação institucional exigida pelos EUA no imediato pós-guerra. Até recentemente, sua aplicação era feita de forma bastante flexível, porque submetida aos objetivos de política industrial ${ }^{64}$, havendo uma mudança gradual de status e importância da política de concorrência ao longo do processo de desenvolvimento econômico do país ${ }^{65}$.

Assim, entre 1945 e meados da década de 1970, em que o Estado japonês empreendeu forte política de fomento industrial, não apenas houve estímulo à concentração de setores estratégicos, mas também a permissão de acordos de cooperação, e em alguns casos a indução da formação de cartéis, com diversos objetivos (combater a recessão, coordenar o investimento em novos equipamentos, promover as

\footnotetext{
${ }^{63}$ Cf. M. MOTTA, Competition Policy...op. cit., p. 14.

${ }^{64}$ Idem.

${ }^{65}$ Cf. J. FAGUNDES, Políticas Industrial e de Defesa da Concorrência no Japão, Revista do Ibrac (1998).
} 
exportações, entre outros). Além disso, reconhecendo as diferentes necessidades de desenvolvimento de cada setor da indústria, a autoridade encarregada da formulação da política industrial japonesa (MITI) possibilitou, inclusive, o desenho de diversas normas de concorrência com vistas a atender a essas especificidades ${ }^{66}$.

Diante disso, à semelhança do caso europeu, a noção de concorrência determinante da orientação das políticas industrial e antitruste no Japão revela-se como um processo de geração e difusão de inovações (em sentido schumpeteriano, que será abordado a diante), o qual não pode prescindir da existência de poder de mercado, capaz de gerar recursos adicionais que incentivam o investimento em inovações. Nessa perspectiva, segundo H. J. Chang $^{67}$, a concentração do poder econômico e os comportamentos anticompetitivos que dele sejam decorrentes não podem ser justificados caso não conduzam à inovação.

A partir da década de 1980, passada a fase do "milagre" industrial japonês, a política de concorrência passa a prevalecer sobre a política industrial, aproximando-se progressivamente ao paradigma norte-americano, principalmente nos anos 1990, com o advento da globalização econômica.

Em relação ao caso da Coréia, que até os anos 1950 era considerada um país atrasado, trata-se de um exemplo de uma trajetória bem sucedida de transformação industrial e tecnológica, no período das últimas décadas. Isso se deve, entre outros fatores, a uma atuação ativa por parte do Estado na promoção de grandes empresas (os "Chaebol") - por meio do estabelecimento de metas para exportação, desenvolvimento de novos produtos e tecnologias - que se capacitaram para competir internacionalmente. Tais medidas vieram acompanhadas pela flexibilização da aplicação antitruste (à semelhança do caso japonês, em que esteve submetido à política de fomento industrial) ${ }^{68}$.

A Coréia do Sul não dispunha de legislação antitruste até 1981 e, mesmo após essa data, eram expressamente permitidos os acordos e a concentração entre empresas pertencentes a setores da indústria com potencial de se desenvolverem e atingirem competitividade internacional ${ }^{69}$.

\footnotetext{
${ }^{66}$ Cf. H. J.CHANG, El Papel del Estado en el Cambio Económico, México, D.F., Ariel, 1996.

${ }^{67}$ Idem.

${ }^{68}$ A. PHAM, National Champions - National Interests Vs. Competition: Where to Strike the Balance, Centre for Competition, Investment \& Economic Regulation (CUTS), Briefing Paper n. 8, (2003).

${ }^{69}$ Cf. H. J. CHANG, El Papel del Estado...op. cit., p. 162.
} 


\section{A disciplina da concorrência nos países em desenvolvimento}

A preocupação com a defesa da concorrência difundiu-se nos países em desenvolvimento principalmente nos anos 1990, como reflexo da intensificação dos processos de globalização e liberalização financeira, e das mudanças estruturais por eles impulsionadas: privatizações e desregulação, no plano interno aos países, e a extraordinária onda de fusões e aquisições, em âmbito internacional ${ }^{70}$. Conforme registra A. Singh, mais de 50 países em desenvolvimento das diferentes regiões do mundo adotaram legislações de defesa da concorrência nessa época, como é o caso do Brasil, que em 1994 promulgou a Lei 8.884. Em junho de 2000, outros 27 países estavam em fase de elaboração de suas legislações ${ }^{71}$.

Nesse particular contexto de transformações político-econômicas em que se dá a ascensão da disciplina concorrencial, verifica-se a difusão de idéias e valores que reforçaram, por um lado, a crença no sistema de mercado como mecanismo neutro, impessoal e espontâneo de formação de $\operatorname{preços}^{72}$ que, além de constituir o resultado natural do comportamento humano, teria a qualidade de otimizar o bem-estar nas diferentes esferas da vida social ${ }^{73}$. Por outro lado, propagou-se também o descrédito na capacidade estatal de assegurar os interesses da coletividade ${ }^{74}$ - embora tida como indispensável para proteger a concorrência como instância alocadora de recursos, coibindo abusos e eventuais disfunções nos mercados - servindo como justificativa para as reformas que reduziriam o espaço e a influência do Estado na esfera econômica.

Sob a hegemonia dessa visão singular dos fenômenos econômicos, o aporte neoclássico pretendeu fixar-se como único referencial teórico válido e legítimo para explicar o correto funcionamento dos mercados e propor políticas para essa área, vindo a ser tomado, nas últimas décadas, como verdadeiro "guia" para a política econômica. No campo do direito da concorrência, particularmente, essa abordagem impingiria à

${ }^{70}$ Cf. A. SINGH, Competition and Competition Policy in Emerging Markets: International and Developmental Dimensions, G-24 - Discussion Paper n. 18, United Nations Conference on Trade and Development, (2002).

${ }^{71}$ Idem, p. 7.

${ }^{72}$ Cf. R. ABRAMOVAY, Entre Deus e o Diabo: Mercados e Interação Humana nas Ciências Sociais, Tempo Social - Revista de Sociologia da USP, vol. 16, n. 2, (2005).

${ }^{73}$ Ver a respeito L. DUMONT, Homo Aequalis - Gênese e Plenitude da Ideologia Econômica (trad. J. L. Nascimento), Bauru, EDUSC, 2000, e também R. ABRAMOVAY, Entre Deus e...op. cit.

${ }^{74}$ Para uma visão crítica sobre essas teorias do Estado, v. P. EVANS, Autonomia e Parceria - Estados e Transformação Industrial, (Trad. C. B Tigres), Rio de Janeiro, UFRJ, 2005. 
recomendação dos organismos internacionais. $\mathrm{O}$ fato de ter havido progressiva convergência entre as práticas antitruste dos países do centro - Estados Unidos, Europa e Japão - induziu à proposição de que o único modelo viável e adequado aos países em desenvolvimento deveria priorizar a eficiência econômica em sentido alocativo, com foco no bem-estar do consumidor, assumindo os mesmos contornos do paradigma anglo-saxão de disciplina concorrencial ${ }^{75}$. A idéia de coordenar o grau de concorrência nos diferentes setores da economia com instrumentos de política industrial era, portanto, mal vista, sendo esta última tomada como distorcedora do sistema de preços.

Nesse quadro, e olhando sob a perspectiva dos países em desenvolvimento - que não completaram seus processos de industrialização e são carentes de estruturas empresariais competitivas em alguns setores - alguns autores questionaram a precocidade destes adotarem políticas de defesa da concorrência. Manifestaram, ainda, a preocupação de que a aplicação estrita da disciplina concorrencial - e dentro dos moldes neoclássicos, perseguindo o equilíbrio paretiano e abrindo mão de políticas de fomento para determinados ramos - poderia ter como efeito o potencial de constranger a formação de grandes grupos econômicos, elemento indispensável para a competitividade desses países.

Assim, os trabalhos de H. J. Chang, R. Dhumale \& A. Singh e A. Singh, entre outros, abordaram a importância de criar instituições que atendessem às particularidades das economias em desenvolvimento, ao invés de simplesmente reproduzir aquelas existentes nos países do centro, indicando as políticas de concorrência adotadas no Japão (entre 1950 e 1970) e na Coréia do Sul, na década de 1980, como exemplos bem sucedidos da prevalência de objetivos desenvolvimentistas, principalmente pelo fato de não terem prescindido da utilização de instrumentos de política industrial para coordenação da atividade econômica.

No foco dessas proposições, reside a idéia de possibilitar a concentração em determinados setores, com vistas à formação de grandes empresas nacionais aptas a concorrer internacionalmente - ainda que no curto prazo e no plano interno aos países isso pudesse acarretar perdas do ponto de vista do bem-estar do consumidor - para o que seria fundamental coordenar a regulação da concorrência com mecanismos de

75 V. R. DHUMALE \& A. SINGH, Competition Policy, Development and Developing Countries, in Trade-Related Agenda, Development and Equity - working papers, Cambridge, South Centre, (1999). Além disso, relatam os autores, com a crescente internacionalização da concorrência, vislumbra-se a proposta OCDE/OMC de implementação de um regime internacional para a defesa da concorrência, no qual os ordenamentos jurídicos nacionais convergiriam em direção às proposições da teoria econômica neoclássica. 
política industrial. Na prática, tais medidas buscam relativizar a horizontalidade subjacente à garantia das condições de concorrência, ao menos até que as economias em desenvolvimento pudessem atingir um estágio mais avançado de estruturação e consolidação industrial.

Resumidamente, dois tipos de argumentos embasam essas concepções. No campo teórico, um primeiro conjunto de considerações aponta que a relação entre concorrência e desenvolvimento econômico seja controvertida, embora a abordagem ortodoxa postule uma relação sempre virtuosa. Partindo da crítica à moldura estática da concepção de concorrência utilizada como referencial para orientar a disciplina antitruste - no sentido da proposição de que a condição ideal, para qualquer mercado, corresponderia ao grau máximo de competição - sustenta-se a sua limitação para lidar com problemas que tipicamente aparecem nas economias em desenvolvimento, tais como a inexistência ou incompletude de determinados mercados. Essas situações, que não são referidas no discurso econômico dominante, exigem atuação do Estado para coordenar decisões de investimentos e prevenir excesso de capacidade. Assim, o grau de competição deveria ser especificado para cada setor da atividade econômica, de acordo com o seu nível de desenvolvimento econômico, o que demandaria um manejo suficientemente flexível das normas antitruste a fim de dar conta dessas especificidades, além de sua coordenação com outros instrumentos de política ${ }^{76}$.

Considerações dessa natureza levam em conta uma dimensão dinâmica dos processos competitivos - e não captada no modelo teórico neoclássico - por envolverem a capacidade de estabelecer um fluxo contínuo de inovação em uma determinada indústria, o que só pode ser apreendido no longo prazo. Essa perspectiva analítica se desenvolve sobretudo a partir da obra de J. A. Schumpeter ${ }^{77}$, na primeira metade do século XX. Ao conceber a economia capitalista como um processo de mudança, impulsionado por inovações e descontinuidades, o autor atribui à dinâmica o aspecto preponderante da concorrência nos mercados, definindo-a como um processo de "destruição criadora”: “(...) um processo de mutação industrial (...) que revoluciona incessantemente a estrutura econômica a partir de dentro, destruindo incessantemente o antigo e criando elementos novos ${ }^{78,}$.

\footnotetext{
${ }^{76}$ H. J. CHANG, El Papel del Estado...op. cit., p. 163.

${ }^{77}$ Capitalismo, Socialismo e .., op. cit.

${ }^{78}$ Idem, p. 105 e ss.
} 
O elemento dinamizador da concorrência é o processo de inovação resultante da tentativa de diferenciação entre os competidores. Ela se materializaria na contínua introdução de novos bens de consumo, métodos de produção ou transporte, novos mercados e formas diversificadas de organização industrial, os quais permanentemente afetam o desempenho industrial, destruindo estruturas pré-existentes e criando novas formas de domínio nos mercados ${ }^{79}$.

Vistos por este ângulo, concorrência e monopólio não correspondem a condições necessariamente opostas, mas são tratadas como posições geradas dentro de um mesmo processo de interação estratégica entre atores econômicos que buscam se diferenciar dos demais concorrentes e conquistar poder de mercado ${ }^{80}$. Como conseqüência, na tradição schumpeteriana, a concorrência é vista sob outros prismas que não apenas a disputa de preços, mas assume - especialmente no âmbito das grandes empresas oligopolistas diferentes formas (tecnológica, produtiva, comercial, organizacional, de mercado, estratégica $)^{81}$.

No que se refere à avaliação dos efeitos do processo competitivo sobre o bem estar (ou eficiência), essa interpretação dispensa a primazia ao equilíbrio e à otimização alocativa, focalizando, ao invés, os elementos de natureza dinâmica necessários à conformação de um ambiente competitivo, isto é, a geração e difusão de inovações em ritmo intenso ${ }^{\mathbf{8 2}}$. Por essa razão, importa notar, a definição de eficiência (dinâmica) exige um espectro de mais longo prazo.

As principais implicações normativas desta abordagem referem-se à ampliação do espaço e modificação da natureza atribuída à ação estatal direcionada à construção e manutenção das condições de dinamismo nos mercados as quais, como mencionado, são freqüentemente ausentes em economias em desenvolvimento. Neste quadro teórico, considera-se que a concorrência e a competitividade não surgem espontaneamente, mas resultam de medidas deliberadas de política, integradas em torno desse objetivo comum. Desse modo, ao pretender-se induzir determinados comportamentos econômicos socialmente desejáveis condizentes com a necessidade de assegurar as condições de dinamismo da concorrência - tais como a adoção, pelas empresas, de estratégias

\footnotetext{
${ }^{79}$ Idem, capítulo 7.

80 “(...) Tem-se, portanto, em sentido rigoroso, que nem os lucros são 'normais' (...), nem situações monopolísticas são intrinsecamente anticompetitivas, pois constituem o objetivo mesmo, e muitas vezes o resultado, do processo competitivo, ainda que de forma temporária e restrita; vale dizer, monopólio não é o 'contrário' de concorrência”. Cf. S. POSSAS, Concorrência e Competitividade - Notas Sobre a Estratégia e Dinâmica Seletiva na Economia Capitalista, São Paulo, Hucitec, 1999, p. 17.

${ }^{81}$ Cf. M. L. POSSAS et alii, Política Antitruste...op. cit., p. 19.

${ }^{82}$ Idem, p. 27.
} 
inovativas, e o uso de critérios de eficiência produtiva - consideram-se relevantes a implementação pelo Estado tanto de medidas regulatórias voltadas à infra-estrutura, aspectos sociais (como qualificação da mão-de-obra, por exemplo) e a obtenção de condições macroeconômicas favoráveis ao crescimento e financiamento, como também o uso de instrumentos de política industrial e defesa da concorrência ${ }^{\mathbf{8 3}}$.

Neste caso, a disciplina da concorrência reuniria as seguintes características ${ }^{\mathbf{8 4}}$ : (i) foco no controle de condutas; (ii) ênfase na concorrência oligopolística, entendida como referencial mais apropriado de análise, em oposição ao paradigma da concorrência perfeita; (iii) tentativa de promover a eficiência de caráter dinâmico (priorizando a geração e a difusão de inovações em ritmo intenso), motivo pelo qual se propõe uma revisão do conceito e do critério de mensuração da "eficiência",85; (iv) pretensão de considerar os efeitos de longo prazo (e não apenas de curto prazo) das práticas concorrenciais; (v) percepção das barreiras à entrada de concorrentes como síntese da natureza e dos determinantes da concorrência num dado mercado oligopolizado (e não como componente da estrutura do mercado ou como uma possível explicação da determinação dos preços em oligopólios); e, por fim, (vi) preocupação com as margens de lucro dos agentes, consideradas expressão das verdadeiras condições de concorrência e de seu potencial de transformação das estruturas de mercado.

Além da argumentação em torno da insuficiência da teoria econômica ortodoxa para oferecer parâmetros adequados à calibragem da política de concorrência nas economias em desenvolvimento - especialmente em relação ao controle das estruturas de mercado - também são evocados elementos da trajetória dos países que se encontram no centro. Nesse sentido, H. J. Chang ${ }^{86}$ e A. Singh ${ }^{87}$ apontam para a evidência histórica de que esses países também relativizaram a ênfase no uso dos mecanismos de regulação da concorrência durante seus respectivos processos de industrialização e também em momentos de acirramento da competição internacional, conforme abordado no tópico anterior.

Em suma, o que diferencia as visões destes autores críticos à ortodoxia, cujas idéias gerais foram sintetizadas acima, consiste na preocupação de que um manejo

\footnotetext{
${ }^{83}$ Idem, p. 18.

${ }^{84}$ A partir da leitura de M. L. POSSAS et alii, Política Antitruste...op. cit.

${ }^{85}$ Para M. L. POSSAS, ao invés de considerada no curto prazo como correspondente à diminuição dos custos de produção, o conceito deveria incluir variáveis características das especificidades de cada mercado, levando também em conta a estrutura de produção, processos produtivos e, principalmente, investimentos em inovação. Política Antitruste: Um Enfoque Schumpeteriano...op. cit., pp. 25-28.

${ }^{86}$ Especialmente em Kicking Away the Ladder...op. cit.

${ }^{87}$ Em Competition and Competition Policy in Emerging Markets...op. cit.
} 
"acadêmico" das normas antitruste, isto é, seguindo à risca o modelo de política proposto pelos países de economia mais avançada, poderia dificultar o processo de concentração necessário à consolidação de alguns setores. Isso porque, de um lado, uma vinculação estrita ao paradigma da concorrência perfeita poderia resultar na obstrução de operações que levassem a níveis de concentração que afetassem negativamente o bem-estar no curto prazo. De outro lado, porque a visão ortodoxa superestima o papel da concorrência e o alcance da sua disciplina jurídica como instrumento para regular os mercados, sugerindo que, na sua vigência, os países em desenvolvimento deveriam abrir mão de outros instrumentos de política capazes de afetar diretamente os mercados e ampliar a competitividade das empresas ${ }^{88}$.

\section{Considerações finais}

Este capítulo pretendeu contextualizar e caracterizar as diferentes concepções sobre o papel do direito da concorrência, abordando os conceitos fundamentais à matéria e registrando elementos da sua prática em diferentes sociedades. Foram tratadas algumas das noções econômicas mais fundamentais, as características das regras jurídicas desenhadas para proteger os processos competitivos e também as linhas gerais da história da aplicação da disciplina antitruste em alguns países com tradição nessa área, para em seguida introduzir a perspectiva dos países em desenvolvimento.

Inicialmente, viu-se que a teoria micro-econômica fornece um marco de referência importante para a compreensão dos problemas concorrenciais a que o direito procura dar resposta. As situações representadas pelos modelos de concorrência-perfeita e monopólio, em função dos resultados deles derivados em termos de bem-estar, foram traduzidas em valores a que as legislações pretendem, respectivamente, promover e coibir, tendo de ser compatibilizados com outros valores e interesses existentes.

Nesse sentido, observou-se que o direito antitruste apresenta-se como um mecanismo flexível de regulação da atividade econômica, em que o formalismo jurídico

\footnotetext{
${ }^{88}$ Entre os economistas brasileiros, também enfatizaram a importância de conciliação ou harmonização entre os objetivos das políticas de concorrência e industrial: E. M. M. Q. FARINA, Política Industrial e Política Antitruste: Uma proposta de Conciliação, in Revista do Ibrac, v. 3, n. 8, (1996), J. FAGUNDES Políticas de Defesa da Concorrência e Política Industrial: Convergência ou Divergência?, in Revista do IBRAC, v. 5, n. 6 (1998), E. M. M. Q. FARINA \& P. F. AZEVEDO, Política Industrial e Defesa da Concorrência...op. cit. (2001), M. L. POSSAS et alii, Política Antitruste: Um Enfoque...op. cit. (2002), L. COUTINHO, Política de Concorrência e Desenvolvimento, in Valor Econômico, 02/07/2004, e A. B. SICSÚ \& M. O. L. MELO, Competitividade, Política de Defesa da Concorrência e Soberania Nacional: Avaliações Sobre o Caso Brasileiro, in CADE Informa nº 6, maio, 2007.
} 
(estabelecendo uma distinção precisa entre lícito e ilícito) cede espaço a categorias abertas, cabendo ao intérprete recorrer a critérios de razoabilidade para decidir cada caso concreto. Essa margem de interpretação, por sua vez, é o que possibilita a instrumentalização da disciplina da concorrência a diferentes objetivos de política considerados relevantes para um determinado momento histórico.

Com efeito, o olhar sobre a experiência internacional na matéria notabiliza o fato de que há mais do que a preocupação exclusiva com a eficiência econômica e com a livre-concorrência por trás da aplicação do direito concorrencial, embora esses sejam os valores dominantes no discurso sobre essa temática, especialmente nos anos 1990.

Entre os objetivos possíveis de serem priorizados, a doutrina aponta tanto para objetivos "concorrenciais" propriamente ditos, tais como o bem-estar (excedente total) e bem-estar do consumidor (excedente do consumidor), e também "extra-concorrenciais", incorporando valores como a defesa das pequenas empresas, a liberdade econômica, o combate à inflação, justiça e equidade, competitividade e desenvolvimento econômico, entre outros. Em virtude dessa pluralidade, constatam-se movimentos de aplicação mais rigorosa ou flexível da legislação, tanto nos EUA, como na Europa, Japão e Coréia, como opções deliberadas de política.

Por fim, tendo em conta o particular contexto de ascensão do direito da concorrência nos países em desenvolvimento, buscou-se expor um conjunto de preocupações trazidas por alguns autores no sentido de direcionar a construção e orientação das instituições de defesa da concorrência ao objetivo de promover o desenvolvimento econômico nos países que não completaram seus processos de industrialização.

O próximo capítulo volta-se especificamente ao ordenamento jurídico brasileiro, focalizando os parâmetros estabelecidos para o controle das estruturas de mercado a partir da promulgação da lei 8.884/94. 


\section{CAPÍTULO 2 - A DEFESA DA CONCORRÊNCIA NO BRASIL}

Este capítulo aborda os traços gerais do direito da concorrência no Brasil, focalizando o tratamento concedido ao controle das estruturas de mercado. Inicialmente, trata das origens históricas da disciplina antitruste no ordenamento jurídico nacional. Em seguida, descreve seu enquadramento entre os princípios da ordem econômica constitucional e a evolução da legislação, para então expor os parâmetros consagrados neste ordenamento para a análise de atos de concentração econômica.

\section{Breve histórico}

A presença de disposições acerca das relações de concorrência não é algo novo no ordenamento jurídico brasileiro. Embora desde os anos 1930 tenham proliferado textos legais nessa direção, na prática, tiveram alcance bastante limitado até o início dos anos 1990. Nesse período, a disciplina jurídica da concorrência assumiria um sentido diferente daquele que hoje associamos às regras antitruste, dado seu enfoque voltado à defesa da economia popular. Assim, os primeiros diplomas legais na matéria tinham por escopo uma classificação de ilicitudes penais, sendo as formas de concentração do poder econômico, e particularmente o monopólio, qualificados como crimes ${ }^{89}$.

A ênfase na economia popular - materializada na garantia de que não fossem praticados preços diversos daqueles fixados pelo Poder Público - encontrava justificativa na forma direta que caracterizou a atuação do Estado na economia ${ }^{90}$, durante o tardio processo de industrialização do país. Sobretudo a partir da década de 1970, com base na política substitutiva de importações visando incentivar a formação de grandes empresas nacionais aptas a competir com as empresas estrangeiras, ao Estado

\footnotetext{
${ }^{89}$ T. S. FERRAZ JR., Lei de Defesa da Concorrência - Origem Histórica e Base Constitucional, in Revista dos Mestrandos em Direito Econômico da UFBA, n. 2, pp. 65-74. Algumas das leis que se sucederam na matéria concorrencial são as seguintes: Decreto-lei $n^{\circ} 869 / 38$, Decreto-lei $n^{\circ} 7.666 / 45$, Leis 1521 e 1522 de 1951 e Lei 4137/62.

${ }^{90}$ E. R. GRAU distingue as formas de atuação do Estado no domínio econômico (na qualidade de agente econômico) de dois tipos: por absorção (monopólio) ou participação (economia mista). O Estado também atua sobre o domínio econômico, na qualidade de regulador da atividade econômica, de duas formas possíveis: por indução (incentivos) ou direção (regras impositivas, como o regime de controle de preços). A Ordem Econômica na Constituição de 1988 - Interpretação e Crítica, $7^{\mathrm{a}}$ ed., São Paulo, Malheiros, 2002.
} 
coube a exploração direta de algumas atividades econômicas, cumulada com a tarefa de regulação. Neste último caso, lançando mão de normas de comportamento compulsório, tal como o controle de preços, e valendo-se também de incentivos e estímulos de natureza fiscal e creditícia para alguns ramos da economia ${ }^{91}$.

Nesse contexto de estruturação da indústria brasileira, portanto, é compreensível que o direito da concorrência tenha desempenhado um papel marginal, porquanto desprovido de eficácia material ${ }^{92}$. Especialmente em relação ao controle da concentração do poder econômico, deve-se notar que o aparente descaso com a implementação das normas de defesa da concorrência, na realidade, atenderia a uma função "estratégica" 93 . Isso porque a política econômica que perdurou até o início dos anos 1980 tinha como foco justamente facilitar o fortalecimento do poder econômico das empresas domésticas como condição para que pudessem concorrer internacionalmente.

Todavia, na década de 1990 ocorrem mudanças fundamentais nesse quadro. Em virtude das transformações estruturais impulsionadas pelas tendências mundiais de liberalização e globalização financeira, fatores como a extraordinária onda de fusões e aquisições globais, em âmbito internacional, e a substancial mudança de direção da política econômica, no plano interno, colocaram a defesa da concorrência em destaque.

Desse modo, em março de 1990, com a adoção pelo Governo Federal brasileiro de medidas como a abertura comercial, desregulação e privatizações - voltadas a diminuir a influência direta do Estado no domínio econômico e fortalecer sua atividade reguladora - ressurge a lei antitruste como uma peça fundamental ${ }^{94}$. Assim, a Lei 8.158 promulgada em janeiro de 1991 cria a Secretaria Nacional de Direito Econômico, órgão vinculado ao Ministério da Justiça, com competência para fiscalizar a ocorrência de

\footnotetext{
91 Segundo O. YAZBEK, os Planos Nacionais de Desenvolvimento, I PND (1971) e II PND (1974) corporificam esse espírito. Contêm a definição de objetivos "nacionais" e de um conjunto de medidas estratégicas direcionadas a alcançá-los, consolidando a adoção de políticas de incentivo e financiamento à atividade industrial. Política Econômica, Legislação Societária e a Aplicação do Direito da Concorrência no Brasil, in RDM, v. 39, n. ${ }^{\circ}$ 117, jan/mar (2000), pp. 136-149.

92 Conforme relata Gesner Oliveira, ex-Presidente do CADE - Conselho Administrativo de Defesa Econômica (autoridade responsável pela decisão de processos envolvendo questões concorrenciais), "a evolução histórica do número de julgados da autarquia confirma a análise prévia da preponderância da vertente intervencionista de proteção à economia popular em detrimento da defesa da concorrência. (...) 74\% das decisões do CADE, no período de 1962 a 2000, foram tomadas entre 1996 e 2000”. Concorrência: panorama no Brasil e no mundo, São Paulo, Saraiva, 2001, p. 9.

${ }_{93}$ Cf. O. YAZBEK, Política Econômica, Legislação Societária...op. cit., p. 141.

${ }^{94}$ Cf. T. S. FERRAZ JR., Lei de Defesa da Concorrência...op. cit., p. 71.
} 
"anomalias de comportamento econômico, capazes de ferir os princípios da ordem econômica" 95 .

Em 1994, o advento da Lei $\mathrm{n}^{\circ} 8.884$ assinala definitivamente a nova etapa da defesa da concorrência no Brasil e o abandono da ênfase na proteção da economia popular. Em contraste com os diplomas legais que a antecederam, marcados pelo caráter penal, assume um viés regulatório, estabelecendo parâmetros para o controle estatal sobre atos de concentração econômica e condutas nos mercados, com vistas a prevenir e repreender o abuso de poder econômico.

Para tanto, do ponto de vista institucional, há o fortalecimento do CADE Conselho Administrativo de Defesa Econômica - a autoridade competente para decidir sobre matéria antitruste, que passa a constituir autarquia federal, além de dispor de dotação orçamentária própria e uma procuradoria especializada. O aumento exponencial do número de julgados em questões concorrenciais, de 1994 em diante, atesta a crescente valorização da atuação do Sistema Brasileiro de Defesa da Concorrência, como também a eficácia material adquira pela legislação vigente.

\section{O valor da concorrência}

A legislação antitruste brasileira vem especificamente a dar concretude ao princípio estatuído no art. $173 \S 4^{\circ}$ da Constituição Federal de 1988, que ordena a repressão ao abuso de poder econômico que vise à dominação dos mercados, à eliminação da concorrência e ao aumento arbitrários dos lucros. A finalidade da Lei 8.884/94 é apresentada em seu artigo $1^{\circ}$, nos seguintes termos:

Esta lei dispõe sobre a prevenção e repressão às infrações contra a ordem econômica, orientada pelos ditames constitucionais de liberdade de iniciativa, livre concorrência, função social da propriedade, defesa dos consumidores e repressão ao abuso de poder econômico. Parágrafo único - a coletividade é titular dos bens jurídicos protegidos pela lei.

Com efeito, há que se notar que a inserção da disciplina da concorrência entre os princípios da ordem econômica fixados pela Constituição traz-lhe dois traços (mais bem limitações) fundamentais. Em primeiro lugar, exige a sua harmonização com os demais

\footnotetext{
${ }^{95}$ Idem.
} 
princípios ali expressos (art. 170 e incisos) e incorporados no texto do artigo $1^{\circ}$ da Lei 8.884. Isso implica, como assinala T. S. Ferraz Jr., que

não se pode defender a concorrência a custa da soberania nacional, do consumidor, do meio ambiente, da redução de desigualdades regionais e sociais, da busca do pleno emprego, do tratamento favorecido às empresas nacionais de pequeno porte. $\mathrm{E}$ vice-versa: nenhum desses princípios será defendido a custa da livre concorrência ${ }^{96}$.

Igualmente, coloca-se a defesa da concorrência a serviço das finalidades maiores positivadas no texto constitucional, isto é, "assegurar a todos existência digna, conforme os ditames da justiça social" (art. 170, caput), respeitadas a livre-iniciativa e a valorização do trabalho humano ${ }^{97}$. Tais delineamentos, por sua vez, autorizam o entendimento da doutrina segundo o qual no ordenamento jurídico brasileiro a concorrência é tutelada enquanto meio para a consecução de outros objetivos, e não como um fim em si mesmo.

A principal conseqüência, como destaca P. A. Forgioni, é que ao invés de mero instrumento corretivo de desvios ou abusos nos mercados, a Lei $n^{\circ} 8.884 / 94$ - tanto ao ser aplicada ao caso concreto, como ao ser dele afastada - viabiliza a implementação de uma determinada política econômica. Destarte, tem sentido o uso dos termos "política antitruste" ou "política de concorrência" para designar a experiência em aplicação do direito da concorrência, precisamente por realçar sua (muitas vezes negligenciada) dimensão política. Assim, cumpre destacar que, em se tratando de instrumento para uma política pública, a disciplina da concorrência poderá então ser implementada com vistas a acolher uma pluralidade de objetivos possíveis, especificados no ordenamento jurídico (e, portanto, em conformidade com as disposições constitucionais) para um determinado momento histórico ${ }^{98}$.

\footnotetext{
${ }^{96}$ Da Abusividade do Poder Econômico, in Revista de Direito Econômico, n.21, out/dez (1995).

97 A respeito do enquadramento constitucional da matéria antitruste, ver E. R. GRAU, A Ordem Econômica na Constituição de 1988...op. cit, pp. 250-255, como também S. V. BRUNA, O Poder Econômico e a Conceituação do Abuso em seu Exercício, São Paulo, RT, 1997.

${ }^{98}$ Cf. P. A. FORGIONI, Os Fundamentos do Antitruste...op. cit., p. 150 e ss. Ver também E. R. GRAU, A Ordem Econômica...op. cit., p. 252 e ss.
} 


\section{A Lei ${ }^{0} 8.884 / 94$ - traços gerais}

Ao estabelecer a moldura dentro do qual a concorrência nos mercados poderá se realizar livremente, delimitando o campo em que o exercício do poder econômico será considerado legítimo e não abusivo, a lei antitruste aplica-se, em princípio, a todos os setores da economia nacional. À diferença do que ocorre em outros países, como Canadá, Estados Unidos e também na União Européia, não há, no caso brasileiro, previsão expressa de imunidade à disciplina concorrencial para qualquer setor ou atividade econômica específica ${ }^{99}$.

A análise e decisão das questões concorrenciais são tarefas dos órgãos que integram o Sistema Brasileiro de Defesa da Concorrência: à Secretaria de Acompanhamento Econômico (SEAE), vinculada ao Ministério da Fazenda, e à Secretaria de Direito Econômico (SDE), ligada ao Ministério da Justiça, atribui-se a instrução e investigação das infrações à ordem econômica. Compete ao Conselho Administrativo de Defesa Econômica (CADE) julgar e decidir os casos concretos, aplicando sanções, quando constatadas ilegalidades.

A atuação das autoridades de defesa da concorrência realiza-se sob dois enfoques distintos: o controle sobre os comportamentos dos agentes econômicos nos mercados e o controle das estruturas organizativas das relações entre esses atores. $\mathrm{O}$ primeiro volta-se para a disciplina da utilização de meios ilícitos para aquisição ou aumento de poder de mercado, sendo considerados como tais aqueles que possam ter como efeito, ainda que os mesmos não se concretizem, a limitação ou falseamento da concorrência (art. 20, inc. I da lei 8.884), a dominação de mercado relevante de bens ou serviços (art. 20, inc. II) ou o exercício abusivo de posição dominante (art. 20, inc. III). $\mathrm{O}$ art. 21 da lei brasileira oferece um rol exemplificativo das possíveis condutas anticompetitivas, incluindo práticas como venda casada, preços predatórios e acordos entre concorrentes para fixação de preços ou divisão de mercados, entre outras.

\footnotetext{
${ }^{99}$ C. SALOMÃO FILHO nota que, embora sem previsão expressa à imunidade, a não aplicação do direito da concorrência só poderia ocorrer em hipóteses excepcionais, em que um determinado setor econômico seja submetido pelo Estado a uma regulamentação especial, supletiva ou substitutiva das forças de mercado. Um caso possível incluiria as atividades econômicas definidas como serviços públicos, quando realizadas por particulares sob concessão ou permissão (art. 175, CF), em regime de monopólio, portanto, passando o Estado a regulamentar o setor com vistas a assegurar a proteção dos interesses dos usuários do serviço ou consumidores do produto (com objetivos redistributivos). Diferentemente, nos casos em que a regulamentação estatal tivesse por fim corrigir imperfeições no sistema de mercado (e não substituí-lo), dos quais constitui exemplo certos setores como energia elétrica e telecomunicações, a disciplina concorrencial teria lugar. Direito Concorrencial: As Estruturas...,op. cit., pp. 218-232.
} 
Por meio do controle estrutural, por sua vez, pretende-se dar atenção às operações de concentração e cooperação entre empresas - tais como fusões, aquisições, incorporações e joint ventures - cujos efeitos no mercado possam implicar prejuízos à concorrência, a fim de preveni-los, quando possível, ou sancioná-los. O art. 54 da lei 8.884/94 apresenta os critérios necessários para determinar quais operações devem obrigatoriamente sujeitar-se ao controle pelo CADE, como também indica os requisitos para que sejam aprovadas.

Tanto nos casos envolvendo condutas ${ }^{100}$, como em relação ao controle de estruturas de mercado, as autoridades antitruste avaliam, em cada caso concreto, se estão presentes condições que permitam identificar a existência de poder de mercado (com uso dos chamados "critérios de identificação") passando, em hipótese afirmativa, à verificação da possibilidade de haver abusos no exercício desse poder, para que esses casos sejam corretamente sancionados (utilizando os chamados "critérios de sancionamento") ${ }^{101}$.

Tendo em vista que os processos de atos de concentração constituem a atividade preponderante do CADE - além da interface mais direta com a questão da competitividade apontada no capítulo anterior - optou-se aqui por apresentar de forma esquemática os procedimentos gerais e os critérios utilizados no exame desses casos, deixando de fora, portanto, a avaliação sobre condutas anticompetitivas. Pela mesma razão é que o presente trabalho se atém, mais adiante, à análise das decisões sobre atos de concentração econômica envolvendo o setor petroquímico.

\section{O controle de atos de concentração - procedimentos e critérios de análise}

No Brasil, após um período de declarado incentivo às concentrações (até os anos 1980), que resultou na ineficácia da legislação concorrencial, registrou-se, entre 1994 e 1996 um índice elevado de intervenções do CADE nas operações. Nessa primeira etapa,

\footnotetext{
${ }^{100}$ A Resolução n. 20/99, em seu anexo, consagrou a interpretação de que não há infração per se na legislação brasileira, isto é, independentemente da intenção do agente e dos resultados alcançados: "A análise de condutas anticoncorrenciais exige exame criterioso dos efeitos das diferentes condutas sobre os mercados à luz dos arts. 20 e 21 da Lei 8.884/94. As experiências nacional e internacional revelam a necessidade de se levar em conta o contexto específico em que cada prática ocorre e sua razoabilidade econômica. Assim, é preciso considerar não apenas os custos decorrentes do impacto, mas também o conjunto de eventuais benefícios dela decorrentes de forma a apurar seus efeitos líquidos sobre o mercado e o consumidor".

101 Para uma caracterização detalhada dos critérios de identificação e sancionamento do poder de mercado, ver C. SALOMÃ̃ FILHO, Direito Concorrencial - As Estruturas...,op. cit., capítulos 2 e 3.
} 
segundo o ex-Presidente do Conselho Gesner Oliveira, o requisito para aprovar atos de concentração era a comprovação de eficiências. Após esse curto período inicial, houve mudança nesse critério e progressiva diminuição da taxa de intervenção nas operações. A pré-condição para a aprovação passa a ser que a transação não apresente efeitos anticompetitivos. Essa tendência se confirma ao visualizarmos os números em relação às decisões proferidas pelo Conselho nos últimos anos:

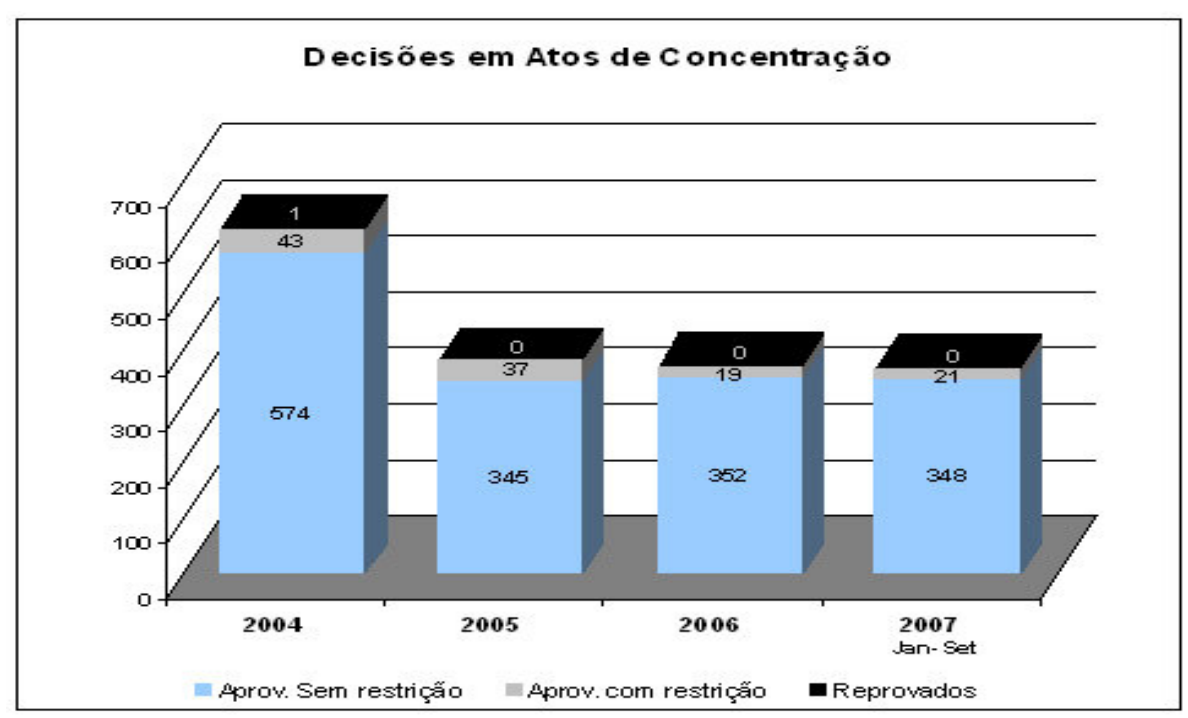

Fonte: $\mathrm{CADE}^{102}$

A sistemática de análise adotada pelo CADE incorpora a técnica consagrada na legislação de concorrência norte-americana, denominada "regra da razão". Com efeito, dispõe o artigo 54 da Lei n. ${ }^{\circ} 8.884 / 94$, em seu inciso III, que os atos ou contratos previstos no caput "não impliquem eliminação da concorrência de parte substancial de mercado relevante de bens e serviços". Nos parágrafos do mesmo dispositivo estão enumeradas as justificativas aceitas para que tais restrições não sejam sancionadas, incluindo-se a eficiência, a repartição dos benefícios obtidos com o consumidor e o progresso tecnológico e econômico.

Conforme relato do ex-Presidente do CADE, Gesner Oliveira, foi necessária a regulamentação do art. 54 para permitir que a análise "custo-benefício" de cada operação para o mercado fosse realizada com critérios comuns. Na prática, o exame desses aspectos passou a ser realizado pelos órgãos do SBDC com base na metodologia consolidada no Guia para Análise Econômica de Atos de Concentração Horizontal

102 www.cade.gov.br (acesso em 03/11/2007) 
$(\text { Guia })^{103}$. De acordo com esse documento, a análise de atos de concentração tem por objetivo avaliar os prováveis efeitos dessas operações e impedir que estas tenham efeitos líquidos negativos sobre o bem-estar econômico, decorrentes da eliminação da concorrência.

Considera-se que tais operações não reduzem o bem-estar econômico, gerando efeitos líquidos não-negativos quando:

(a) Não geram o controle de parcela significativa do mercado;

(b) Geram o controle de parcela substancial de mercado, mas for baixa a probabilidade de exercício de poder de mercado; ou

(c) Geram o controle de parcela substancial de mercado e for provável o exercício de poder de mercado, mas apresentam eficiências econômicas (efeitos positivos) suficientes para compensar seus potenciais efeitos negativos.

O processo de avaliação dessas variáveis é maleável, como se verá, permitindo que sejam considerados aspectos relevantes de cada caso concreto e a obtenção de resultados bastante diversificados ${ }^{104}$, condizentes com os objetivos da política pública que instrumentaliza. O procedimento geral envolve cinco etapas principais de análise, abaixo apresentadas.

De acordo com a legislação vigente, estão sujeitos ao crivo do SBDC os atos ou operações que promovam a concentração e cooperação entre agentes econômicos - tais como fusões, aquisições e conglomerações - quando impliquem em participação de empresa ou grupo de empresas resultante em $20 \%$ (vinte por cento) de um mercado relevante, ou quando qualquer dos participantes tenha registrado faturamento bruto anual no último balanço equivalente a $\mathrm{R} \$ 400.000 .000$ (quatrocentos milhões de reais), $\left(\operatorname{art} .54 \S 3^{\circ}\right)$.

Atualmente, a atuação das autoridades antitruste se dá com base em um sistema que possibilita a notificação das operações, pelas partes interessadas, a posteriori, as quais devem, no entanto, atender ao prazo máximo de 15 dias úteis contados da data de sua realização $\left(\operatorname{art} .54, \S 4^{\circ}\right)^{105}$. Recebida a notificação da operação, a SDE e a SEAE realizam a instrução dos casos e emitem seus pareceres. Após análise, cabe ao CADE

${ }^{103}$ Portaria conjunta SEAE/SDE n. ${ }^{\circ}$ 50, de $1^{\circ}$ de agosto de 2001, publicada no Diário Oficial da União DOU $\mathrm{n}^{0}$ 158-E, de 17 de agosto de 2001, Seção 1 , páginas 12 a 15, disponível no sítio www.fazenda.gov.br/seae.

${ }^{104}$ Cf. P. A. FORGIONI, Os Fundamentos...op. cit., p. 376.

${ }^{105}$ Esse sistema de notificação a posteriori contrasta com a experiência internacional. Efeitos custosos e risco de desfazimento da operação são argumentos importantes para justificar o controle preventivo. No Brasil, esse aspecto é contemplado pelo projeto de lei que visa alterar a lei 8884/94, atualmente em trâmite no Congresso. 
decidir sobre o ato de concentração, existindo três possíveis resultados: (i) aprovação sem restrições, (ii) aprovação com restrições, ou (iii) não aprovação e desfazimento da operação. No que segue, apresentam-se as etapas do procedimento de análise dessas operações.

\section{$1^{a}$ Etapa: Avaliação dos impactos estruturais}

Envolve a identificação dos mercados envolvidos ou afetados pela operação, a identificação dos agentes que neles atuam e suas respectivas participações de mercado, a fim de avaliar os impactos da operação sobre a estrutura de mercado.

A definição do mercado relevante está relacionada à necessidade dos órgãos do SBDC verificarem a possibilidade de exercício de poder de mercado por parte de uma ou mais empresas. Em sentido jurídico, o mercado relevante deve ser entendido como o mercado "pertinente" para análise de determinada prática ou operação. Trata-se, segundo S. V. Bruna, do contexto em que se manifesta o poder econômico ${ }^{106}$, o que inclui o espaço geográfico e também material no qual a concorrência se estabelece ${ }^{107}$.

Segundo o Guia, o mercado relevante é composto pelos produtos e/ou serviços e agentes que efetivamente limitam as decisões referentes a preços e quantidades da "empresa" resultante da operação. O mercado relevante da operação é determinado em termos dos produtos e/ou serviços que o compõem (dimensão produto) e da área geográfica para qual a venda de tais produtos é viável economicamente (dimensão geográfica).

O instrumental utilizado na identificação dessas variáveis é o chamado "Teste do Monopolista Hipotético”, por meio do qual se avalia qual seria

o menor grupo de produtos e a menor área geográfica necessária para que um suposto monopolista esteja em condições de impor um 'pequeno, porém significativo e não transitório' aumento de preços ${ }^{108}$.

Em relação à dimensão produto, verifica-se a existência de substitutibilidade pelo lado da demanda - sem custos significativos e num curto período de tempo - do(s) produto(s) ou serviço(s) sob análise por outros, devido, por exemplo, a elevações em

${ }^{106}$ O Poder Econômico e a Conceituação...op. cit., p. 83.

${ }^{107}$ A. M. O. NUSDEO, Defesa da Concorrência...op. cit., p. 29.

${ }^{108}$ Item 29 do Guia. 
seus preços. Pelo lado da oferta, observa-se qual a flexibilidade de produção entre o(s) produto(s) em questão e um substituto próximo, diante de tal eventual incremento de preço.

No que se refere à dimensão geográfica, são analisadas as possibilidades de os consumidores - sem custos significativos e num intervalo de tempo razoável - em resposta a um aumento no preço relativo do produto ou serviço relevante, substituírem suas aquisições de ofertantes localizados em um dado território por aquisições de outros ofertantes situados em outras regiões.

Na prática, como observa A. M. O. Nusdeo, a elasticidade do conceito de mercado relevante é o que permite a discussão sobre suas dimensões pelas partes envolvidas numa operação sob exame das autoridades antitruste, e até mesmo a divergência da doutrina com relação aos critérios mais acertados para a sua delimitação.

Nesse último caso, salienta a autora, freqüentemente, a discussão tende a um caráter ideológico, de modo que aqueles adeptos de uma política antitruste mais severa, defensores da necessidade de prevenção da concentração de poder de mercado, tendem a se posicionar em favor da adoção de critérios que resultem no caráter mais restritivo da definição de mercado. Contrariamente, haveria posturas em apoio a uma política econômica mais liberal e permissiva com relação à concentração dos mercados ${ }^{109}$.

Uma vez determinado(s) o(s) mercado(s) relevante(s), os órgãos do SBDC identificam aqueles que nele atuam e suas respectivas participações nas vendas totais do produto ou serviço em questão, antes e depois da operação. Dispondo dessas informações, passa-se à mensuração do grau de concentração resultante da operação em análise, a fim de verificar seu impacto sobre a estrutura de mercado.

Usualmente, adotam-se o Índice Herfindahl-Hirschman (HHI) e o CR4 como indicadores para mensurar o grau de concentração dos mercados antes e após a operação. O primeiro consistente na soma dos quadrados da parcela de participação no mercado de todas as empresas nele atuantes. $\mathrm{O}$ aumento da concentração decorrente da operação seria avaliado com base na comparação das medidas anterior e posteriormente ao ato de concentração, sempre que o quadrado da participação das empresas agrupadas seja maior do que a soma dos quadrados de sua participação individual ${ }^{110}$. O segundo, por sua vez, corresponde à participação percentual conjunta das quatro maiores empresas ofertantes do mercado relevante. No caso da concentração resultante exceder:

${ }^{109}$ Cf. A. M. O. NUSDEO, Defesa da Concorrência...op.cit. p. 31.

${ }^{110}$ Idem, p. 88. 
(i) $20 \%$ ou (ii) $10 \%$ em um mercado onde o índice de concentração $\mathrm{C}_{4}{ }^{111}$ seja igual ou superior a $75 \%$, considera-se que o exercício de poder de mercado unilateral e/ou coordenado é provável e a análise do processo prossegue para as próximas etapas. Caso contrário, considera-se que a possibilidade de exercício de poder de mercado é improvável e a operação é aprovada sem restrições.

\section{$2^{a}$ Etapa: Exame da probabilidade de exercício de poder de mercado}

Tendo sido identificada a presença de poder de mercado no mercado relevante sob exame, o passo subseqüente é a verificação da existência de variáveis que possam inibir seu exercício pela nova empresa, seja de forma unilateral ou coordenada com outros agentes econômicos. As principais variáveis levadas em consideração pelos órgãos do SBDC são: (i) possibilidade de importação, (ii) condições de entrada de novos competidores no mercado e (iii) efetividade da rivalidade entre os concorrentes.

A análise das condições de entrada nos mercados relevantes é fundamental para avaliar os potenciais efeitos negativos sobre o ambiente competitivo decorrentes da eventual operação. Em termos práticos, espera-se que nenhum ato de concentração realizado em mercados relevantes em que as barreiras à entrada sejam baixas gere maiores preocupações nos órgãos do SBDC.

A ausência de barreiras significativas à entrada de novos concorrentes em um determinado mercado relevante implica na impossibilidade de exercício abusivo de poder de mercado por parte de uma empresa que detenha elevado market share. Isto decorre do pressuposto de que condutas que visem extrair rendas de monopólio no mercado relevante em questão podem atrair a entrada de novos concorrentes. De acordo com o Guia, o exercício do poder de mercado será considerado improvável quando a entrada for "provável", "tempestiva" e "suficiente".

A entrada é considerada provável quando ela for economicamente lucrativa a preços pré-concentração e quando estes preços puderem ser assegurados pelo possível entrante. Ou seja, a entrada é provável quando as escalas mínimas para atuação eficiente no mercado forem inferiores às oportunidades de venda no mercado a preços préconcentração. Em relação à tempestividade da entrada, os órgãos do SBDC consideram, em geral, o período de dois anos como prazo aceitável para entrada. Finalmente, a

${ }^{111} \mathrm{O}$ índice $\mathrm{C}_{4}$ é a participação percentual conjunta das 4 maiores ofertantes do mercado relevante. 
entrada será considerada suficiente quando permitir que todas as oportunidades de venda sejam adequadamente exploradas pelos entrantes em potencial.

A discussão sobre a existência de barreiras à entrada deve ser realizada com base nas seguintes dimensões, definidas pelo Guia: (a) custos irrecuperáveis; (b) barreiras legais ou regulatórias; (c) recursos de propriedade exclusiva das empresas instaladas; (d) economias de escala e/ou de escopo; (e) grau de integração da cadeia produtiva; (f) fidelidade dos consumidores às marcas estabelecidas; e (g) ameaça de reação dos competidores instalados.

De acordo com o mesmo documento, ainda que a entrada não seja provável, tempestiva e suficiente, não é possível afirmar que a probabilidade de exercício abusivo de poder de mercado é elevada. A efetividade da competição entre a empresa que adquire participação significativa e seus rivais pode tornar pouco provável o abuso de poder de mercado adquirido. Isto ocorreria caso as empresas estabelecidas adotassem condutas mais agressivas de forma a reagir ao eventual exercício do poder de mercado da concorrente para aumentar ou proteger o seu market share.

A análise da existência de rivalidade entre os concorrentes é realizada, em geral, com base no comportamento dos preços praticados nesses mercados. Dessa forma, verificam-se as principais reações das empresas a aumentos de preços de seus competidores com o intuito de identificar histórico de competição via preços no setor. Nesse sentido, destaca-se que a presença de estruturas de mercado concentradas não é condição suficiente para a ausência de um ambiente competitivo. Dois fatores combinados podem ser indutores de pressões competitivas em mercados com estruturas concentradas: por um lado, as características de homogeneidade do produto, por outro a existência de rivais de grande porte.

A homogeneidade do produto faz com que a fidelidade dos consumidores à determinada marca seja extremamente sensível à variável preço. No caso de um duopólio onde duas empresas oferecem um serviço idêntico, mediante uma pequena redução nos preços uma das empresas poderia "roubar" os consumidores de seu concorrente. A reação da empresa que estaria perdendo participação no mercado seria acompanhar essa redução de preços. No limite, o processo de interação dessas estratégias levaria a um preço próximo ao competitivo, no limite do custo médio das empresas, a despeito do mercado ser bastante concentrado ${ }^{112}$.

\footnotetext{
${ }^{112}$ A possibilidade de que a concorrência via preços em um mercado com características de duopólio é conhecido na literatura econômica como equilíbrio de Bertrand.
} 
Porém, caso não seja comprovada perante as autoridades de defesa da concorrência a rivalidade efetiva entre as empresas atuantes nos mercados relevantes em questão, não ficando caracterizada a baixa probabilidade de exercício de poder de mercado, as autoridades passarão a investigar os eventuais ganhos de eficiência econômica decorrentes das operações.

\section{$3^{a}$ Etapa: Exame das eficiências econômicas específicas geradas pelo ato}

Uma vez identificada a probabilidade de exercício de poder de mercado, analisam-se, nesta etapa, as eficiências geradas pelo ato em questão, com vistas a verificar se seus efeitos compensam o prejuízo à concorrência. Assim, conforme G. Oliveira,

as operações que não prejudicam ou limitam a livre concorrência devem ser aprovadas pela autoridade antitruste sem necessidade de análise das eficiências, ou seja, devem ser aprovadas mesmo que não apresentem eficiências associadas à operação ${ }^{113}$.

Consideram-se eficiências os ganhos de bem-estar oriundos do ato de concentração, que podem decorrer de: (i) economias de escala, (ii) economias de escopo, (iii) introdução de tecnologia mais produtiva, (iv) apropriação de externalidades positivas, (v) eliminação de externalidades negativas ou (vi) geração de um poder de mercado compensatório.

De acordo com os critérios estabelecidos pelo Guia, as eficiências a serem eventualmente apresentadas às autoridades devem se caracterizar por serem:

(a) específicas à operação, isto é, não poderiam ser obtidas por outros meios que não a aquisição do ativo em análise;

(b) derivadas de economias reais, isto é, não representam a mera transferência de recursos entre agentes econômicos;

(c) apresentadas de forma clara e precisa; e

(d) significativas, no sentido de que devem compensar a concentração gerada pelo ato de concentração.

\footnotetext{
${ }^{113}$ Cf. G. OLIVEIRA, Concorrência: Panorama no Brasil...op. cit., p. 26.
} 
$\mathrm{O}$ art. 54 da lei $8.884 / 94, \S 1^{\circ}$, por sua vez, determina que os benefícios das eficiências que justificam a sua autorização pela autoridade antitruste, a despeito do aumento do poder de mercado, sejam compartilhados com o consumidor, nos seguintes termos:

O CADE poderá autorizar os atos a que se refere o caput, desde que atenda às seguintes condições:

I - tenham por objetivo, cumulada ou alternativamente: a) aumentar a produtividade; b) melhorar a qualidade de bens ou serviços; e/ou c) propiciar a eficiência e o desenvolvimento tecnológico ou econômico;

II - os benefícios decorrentes sejam distribuídos equitativamente entre os seus participantes, de um lado, e os consumidores finais, de outro;

III - não impliquem eliminação da concorrência de parte substancial de mercado relevante de bens e serviços; e

IV - sejam observados os limites estritamente necessários para atingir os objetivos visados.

Na prática, contudo, a análise dos atos de concentração dificilmente chega a esta etapa, ficando descaracterizado o potencial prejuízo à concorrência já nas etapas anteriores. Como dito, após todas as fases procedimentais descritas, a autoridade antitruste dispõe de elementos para concluir a respeito dos chamados efeitos líquidos da operação sob análise (termos sob os quais conclui sobre a existência ou não de abuso de poder econômico), decidindo-se se será aprovada sem restrições, com restrições ou não aprovada.

\section{$4^{a}$ Etapa: Motivo preponderante da economia nacional e do bem comum}

Excepcionalmente, ainda que o exame da operação conclua pela existência de condições que impliquem em restrição substancial e injustificada da concorrência, a autoridade antitruste poderá, por motivo preponderante da economia nacional e do bem comum, autorizar a operação em questão. A regra encerrada no $\S 2^{\circ}$ do art. 54 da Lei 8.884/94 abre essa possibilidade:

Também poderão ser considerados legítimos os atos previstos neste artigo, desde que atendidos pelo menos três das condições previstas nos incisos do parágrafo anterior, quando necessários por motivo preponderante da economia nacional e do bem comum, e desde que não impliquem prejuízo do consumidor ou usuário final. 
$\mathrm{Na}$ realidade, esse dispositivo permanece sem utilização no ordenamento brasileiro, sem que haja registro de que tenha sido evocado em alguma decisão do CADE. Trata-se de mais um mecanismo que confere flexibilidade à norma antitruste, viabilizando a implementação de uma política econômica que priorize outros aspectos que não a concorrência "estática”. Exatamente por essa razão, é vista com desconfiança, pois abre a possibilidade para postura mais intervencionista do Estado, alterando, por tanto, o jogo de livre-mercado.

A esse respeito, verifique-se a opinião do Ex-Presidente do CADE, Gesner Oliveira:

\begin{abstract}
Note-se o risco de que regras genéricas dessa natureza permitam indesejável subordinação do controle de fusões à política industrial. Recomenda-se, assim, que a aplicação do dispositivo seja parcimoniosa a fim de evitar precedente de isenção à Lei 8.884/94. Sua possível aplicação deveria ficar restrita a situações em que, no plano jurídico, envolva a defesa de princípio constitucional de valor equiparável ao princípio da livre concorrência; e, no plano econômico, envolva providências no sentido de prevenir a ocorrência de falhas no mercado relevante ou em mercados conexos ${ }^{114}$.
\end{abstract}

Por fim, cabe ainda destacar que o acúmulo de experiência na matéria antitruste trouxe algumas mudanças pontuais na legislação, com vistas a aperfeiçoar e imprimir maior agilidade à tramitação dos processos pelo SBDC. Atualmente, tramita Projeto de Lei propondo o estabelecimento de sistema de análise prévio para atos de concentração (invertendo a regra vigente e convergindo em relação às práticas dos países desenvolvidos) e alterando disposição sobre condutas, assim como a mudança do arranjo institucional da defesa da concorrência, redefinindo-se as atribuições do CADE e SDE.

${ }^{114}$ Concorrência: Panorama no Brasil...op. cit., p. 27 e 28. 


\section{Considerações finais}

Este capítulo abordou os principais marcos de referência que têm conduzido a prática da defesa da concorrência no Brasil, focalizando as disposições voltadas ao controle das estruturas de mercado inauguradas com a Lei 8.884/94. Anteriormente a essa lei, outras foram editadas visando disciplinar as relações de concorrência, mas tiveram um alcance extremamente limitado, sobretudo em função do modelo de política de desenvolvimento adotado no país, que contava com forte apoio do Estado.

Inicialmente, observou-se que no ordenamento jurídico brasileiro a concorrência é valorada enquanto meio, e não como fim em si mesmo, sujeitando-se a aplicação da legislação antitruste à observância de outros princípios constitucionais voltados a configuração da ordem econômica.

Com respeito às principais disposições presentes na Lei $8.884 / 94$, notou-se que incorpora os traços típicos das normas antitruste de outros ordenamentos, contendo expressões abertas, cuja análise exige a ponderação de um conjunto de valores e

princípios relevantes para cada caso concreto. No que se refere à disciplina das estruturas de mercado (fixada no art. 54 da lei) é possível notar que a abertura da norma acabou sendo preenchida, na prática, estreitando-se ao aporte econômico neoclássico, no sentido de priorizar a obtenção de eficiências estáticas como efeito desejável para manutenção das condições de competição.

Esse aspecto se consubstancia na ênfase dada ao Guia de Análise de Atos de Concentração (SEAE/SDE) à verificação dos efeitos líquidos das operações no bemestar do consumidor, tendo reflexo imediato na linguagem e na linha argumentativa tipicamente presentes nos pareceres dos órgãos de defesa da concorrência. Nesse sentido, pode-se dizer que os objetivos concorrenciais propriamente ditos têm sido centrais na análise antitruste realizada pelas autoridades brasileiras.

O fato de a lei 8.884/94 ter sido editada no contexto das reformas de mercado, em que a atuação do Estado na economia era vista com desconfiança, reforça essa característica, que também explica que a legislação antitruste brasileira não tenha conexão explícita com outras políticas voltadas para o mercado. Diferentemente do que ocorreu no Japão e na Coréia, onde o direito concorrencial foi desenhado de forma integrada à política industrial, estabelecendo, por exemplo, isenção para alguns setores, no Brasil esse mecanismo não foi incorporado e os instrumentos de política que 
apoiaram a industrialização sob o modelo substitutivo de importações foram desarticulados. A prioridade central passou então a ser estimular a concorrência.

Por fim, ao percorrer a sistemática de avaliação de atos de concentração, observou-se que embora a legislação estabeleça a abertura do sistema a razões de "manifesto interesse público" - dispositivo que poderia ser interpretado em favor da concentração de setores específicos da economia, que fossem alvo de política deliberada do Estado - o fato de jamais ter sido aplicado denota o predomínio de uma visão particular a respeito dos limites da ação pública para promover e garantir a concorrência.

Identificados os traços fundamentais do direito concorrencial brasileiro, os capítulos subseqüentes procuram analisar a sua aplicação enfocando o caso do setor petroquímico. O próximo capítulo apresenta as características gerais desse setor e suas especificidades no Brasil, além de percorrer a trajetória dos instrumentos de regulação estatal que nele incidiram, com vistas a oferecer um quadro mais completo acerca do contexto em que se insere o direito da concorrência com o advento da Lei 8.884/94. Em seguida, passa-se ao exame dos atos de concentração envolvendo o setor petroquímico na última década (capítulo 4). 


\section{CAPÍTULO 3 - O CASO DA INDÚSTRIA PETROQUÍMICA NO BRASIL}

A indústria petroquímica é uma das mais importantes nas economias modernas. Ao fornecer insumos para uma ampla gama de setores industriais, desempenha um papel particularmente estratégico no conjunto da economia e apresenta grande potencial de contribuir para o desenvolvimento econômico. Por essa razão, o consumo per capita de produtos petroquímicos pode ser utilizado como um indicador de desenvolvimento industrial. Nesse sentido, o Brasil dispõe de um nível de consumo per capita considerado baixo em relação a países vizinhos como a Argentina ${ }^{115}$.

Nos países avançados, a petroquímica teve rápido crescimento após a Segunda Guerra Mundial, em virtude da capacidade de massificar e democratizar hábitos de consumo a partir da substituição de produtos tradicionais - como madeira, papel, vidro, metais, algodão, borracha e sabão - por outros a custos mais baixos, com peso menor e maior resistência, durabilidade e flexibilidade. Entre seus principais produtos destacamse os plásticos, as fibras e borrachas sintéticas, e os detergentes ${ }^{116}$.

Nos países em desenvolvimento, especialmente da América Latina, a implantação da petroquímica ocorreu durante a etapa final da política de industrialização substitutiva de importações, entre o início dos anos 1970 e o término da década de 1980. Contou, portanto, com intenso envolvimento dos Estados nacionais, em alguns casos atuando de forma direta na atividade econômica, caracterizando-se uma espécie de "capitalismo de Estado". Em outros, coube ao setor público a tarefa de proteger o mercado interno e estimular o investimento privado, por meio de mecanismos de promoção fiscal e financeira, estabelecendo-se um "capitalismo assistido" 117 .

Ao final dos anos 1980, as condições de crise, instabilidade econômica e crescente endividamento externo que assolavam praticamente todos os países da região

\footnotetext{
115 Cf. F. S. ERBER e J. C. de OLIVEIRA, A Indústria Petroquímica Brasileira: Uma Perspectiva Histórica. Mimeo, p. 1.

${ }^{116}$ Cf. G. R. SCHUTTE, Elo Perdido - Estado, Globalização e Indústria Petroquímica no Brasil, São Paulo, Annablume, 2006, p. 50.

${ }^{117}$ D. CHUDNOVSKY \& A. LÓPEZ, Auge y Ocaso del Capitalismo Asistido: La Industria Petroquímica Latinoamericana, D. CHUDNOVSKY \& A. LÓPEZ (coord.), Santiago de Chile, CEPAL/IDCR/Alianza Editorial, 1997, p. 15 e 16.
} 
latino-americana, incluindo o Brasil, fortaleceram a crítica que resultou terminal ao modelo desenvolvimentista, criando um ambiente favorável à implantação das reformas pró-mercado.

Nesse contexto, ao início da década de 1990, observa-se no Brasil o desmantelamento do arcabouço regulatório da petroquímica desenhado sob o marco da política de substituição de importações, e a mudança no sentido da criação de instrumentos voltados para promover o funcionamento mais eficiente dos mercados e disciplinar, via concorrência, o comportamento das empresas. Entre os instrumentos utilizados para esse fim, despontam a liberalização comercial, a privatização das empresas estatais, a desregulação dos mercados domésticos e, especialmente relevante para o enfoque deste trabalho, a defesa da concorrência.

Tomando em conta essa mudança de orientação na política de promoção do desenvolvimento, o presente capítulo explora as especificidades da indústria petroquímica no Brasil e a trajetória da regulação do setor, procurando assim caracterizar o objeto e o contexto da ação antitruste em relação a esse ramo determinado da atividade econômica.

\section{Características gerais da indústria petroquímica}

A petroquímica integra o complexo industrial químico, ao lado da química inorgânica e da química fina. Os produtos petroquímicos são obtidos a partir da transformação de hidrocarbonetos naturais - a nafta, que é um derivado de petróleo, ou o gás natural - mediante processos químicos ${ }^{118}$. A nafta é obtida junto às refinarias de petróleo, ao passo que o uso de gás como fonte de matérias-primas exige a localização das plantas petroquímicas próxima aos campos de gás ou o uso de gasodutos ${ }^{119}$. No Brasil, tradicionalmente utiliza-se a nafta; nos demais países da América Latina, por sua vez, o uso do gás natural é predominante ${ }^{120}$.

Os produtos petroquímicos podem ser divididos em três categorias, correspondentes às sucessivas etapas da sua cadeia de produção:

\footnotetext{
118 A. LÓPEZ, Mercados, Coordinación y Jerarquías, in Auge y Ocaso del Capitalismo Asistido: La Industria Petroquímica Latinoamericana, D. CHUDNOVSKY \& A. LÓPEZ (coord.), Santiago de Chile, CEPAL/IDCR/Alianza Editorial, 1997, p. 57.

${ }^{119}$ Cf. F. S. ERBER e J. C. de OLIVEIRA, A Indústria Petroquímica...op. cit., p. 2.

${ }^{120}$ Idem, p. 3.
} 
a) Produtos básicos ou de primeira geração - resultam do processamento das matérias-primas (nafta ou gás natural) pelas centrais petroquímicas e são geralmente utilizados como insumo para os produtos intermediários ou finais do setor. A utilização da nafta como matéria-prima permite obter uma ampla gama de produtos básicos, os quais podem ser subdivididos em olefinas (principalmente eteno, butano e propeno) e aromáticos (benzeno, tolueno, oxileno e p-xileno). Já o emprego de gás como matéria-prima leva à produção majoritária de eteno ${ }^{121}$.

b) Produtos intermediários ou de segunda geração - resultam do processamento dos produtos básicos e praticamente também não têm uso direto. Aplicam-se na produção de bens petroquímicos finais ou em outros campos da indústria (especialmente a química). Principais exemplos são o óxido de eteno, acetato de vinila, estireno, fenol e formaldeído, entre outros.

c) Produtos finais ou de terceira geração - são obtidos a partir do processamento dos produtos básicos ou intermediários, e servem de insumo de uso bastante difundido pela indústria manufatureira; não são mais transformados por processos químicos. Os produtos finais podem ser agrupados nas seguintes categorias: resinas termoplásticas, resinas termoestáveis, elastômeros, fibras e fios sintéticos, fertilizantes, solventes, detergentes e plastificantes.

A figura a seguir ilustra a cadeia de produção petroquímica ${ }^{122}$ :

${ }^{121}$ Idem, ibidem.

${ }^{122}$ Extraída do parecer SEAE no ato de concentração n. ${ }^{\circ}$ 08012.005799/01-92. 


\section{A Cadeia Petroquímica}

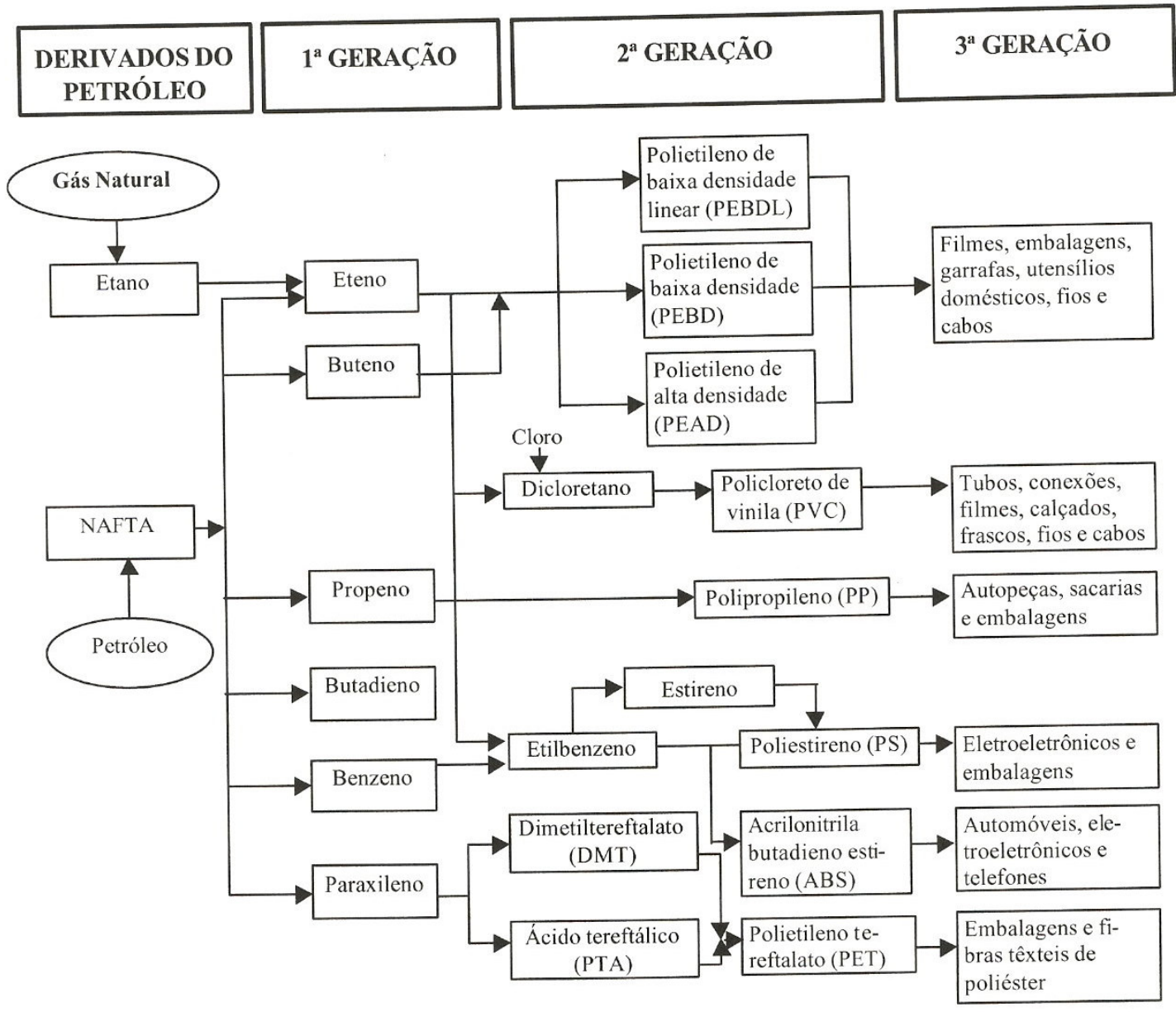

Fonte: Requerentes. Adaptado da publicação "O Mercado do Plástico"; Panorama Setorial; Gazeta Mercantil; $2000 ;$ p. 2.

As características centrais da indústria petroquímica são determinadas por fatores de ordem econômica e também técnica. Em linhas gerais, o setor apresenta uso intensivo de capital, com prazos longos de maturação dos investimentos e economias de escala; dependência de matérias primas específicas e processos de produção altamente integrados ao longo da cadeia; estrutura industrial em oligopólio; alta intensidade tecnológica; e alto grau de internacionalização ${ }^{123}$.

${ }^{123}$ Características enumeradas por G. R. SCHUTTE, Elo Perdido...op. cit., p. 50 e ss., que também se refere a outros dois elementos: concentração geográfica da produção petroquímica em número relativamente pequeno de localizações e o fato do setor ser alvo de atenção contínua da opinião pública, pelo seu potencial impacto como devastador ambiental. 


\section{Intensidade de capital e economias de escala}

No âmbito da fabricação de produtos petroquímicos, os principais aspectos econômicos envolvidos dizem respeito à exigência de elevado volume de capital, dado que tal atividade encerra custos elevados e ditos irrecuperáveis (sunk costs), demandando a imobilização de grande quantidade de capital em equipamentos, instalações e tecnologias que são caros e têm escasso uso alternativo ${ }^{124}$. Como conseqüência, é longo o tempo requerido para que esses investimentos possam gerar lucros (prazo de maturação): em condições normais, entre a tomada de decisão de implantação de uma unidade petroquímica e o momento em que ela entra em operação decorre um período de três a cinco anos ${ }^{125}$.

Além disso, a petroquímica tem como características a forte incidência das matérias-primas no seu custo de produção e o uso de processos de fabricação que são contínuos. Resultam dessas condições a presença de economias de escala - como estratégia para reduzir os custos fixos por unidade produzida e assim enfrentar a acirrada concorrência no setor ${ }^{126}$ - e a tendência ao aumento das escalas mínimas de produção nas plantas. Esta última, por sua vez, ocorre de maneira descontínua, "em saltos", procurando atender a variação da demanda.

\section{Conglomeração e integração}

Constituem também traços fundamentais da produção petroquímica a rigidez dos coeficientes de insumo-produto, a alta dependência de matérias-primas específicas e a obtenção simultânea de vários produtos e subprodutos possibilitando o aproveitamento de economias de escopo ${ }^{127}$. A essas características somam-se o alto custo de transporte, a racionalização da infra-estrutura básica (por exemplo, energia e água) e a maior facilidade de controle ambiental como fatores que, em conjunto, conferem indivisibilidades à cadeia de produção, determinando a sua organização ser concentrada sob a forma de pólos petroquímicos ${ }^{128}$.

\footnotetext{
${ }^{124}$ G. R. SCHUTTE, Elo Perdido...op. cit., p. 50.

${ }^{125}$ Cf. M. A. SUAREZ, Petroquímica e Tecnoburocracia-Capítulos do Desenvolvimento Capitalista no Brasil, São Paulo, HUCITEC, 1986, p. 37.

${ }^{126}$ Cf. G. R. SCHUTTE, Elo Perdido...op. cit., p. 50.

${ }^{127}$ F. S. ERBER e J. C. de OLIVEIRA, A Indústria Petroquímica...op. cit., p. 4.

${ }^{128}$ Cf. G. R. SCHUTTE, Elo Perdido...op. cit., p. 52.
} 
Além disso, a indústria petroquímica traz a integração vertical ${ }^{129}$ como um de seus componentes típicos, em virtude da presença de ativos específicos. Estes correspondem a bens cujo valor de troca é maior ao ocorrer o intercâmbio entre duas firmas específicas do que seria caso envolvesse terceiros, razão pela qual incentivam a substituição de relações contratuais entre empresas independentes por intercâmbios internos à mesma firma ${ }^{130}$, reduzindo os custos de transação. Ao lado destas estruturas totalmente hierarquizadas, convivem também formas intermediárias de coordenação vertical, envolvendo, portanto, unidades autônomas que estabelecem entre si parcerias, contratos de longo prazo, joint ventures, licenciamentos, etc.

Desse modo, existem fortes inter-relações entre os elos da cadeia de produção petroquímica, motivadas em grande parte pela busca de segurança no abastecimento do mercado (sobretudo matérias-primas) para facilitar o planejamento dos investimentos ${ }^{131}$. Com isso, configura-se a interdependência como mais um elemento importante ao setor. Para P. Evans esse traço é tão acentuado que chegou a caracterizar a indústria petroquímica como uma espécie de "capitalismo coletivo", visto que aspectos tecnológicos e organizacionais levam a que o destino de cada uma das plantas dependa do desempenho das outras ${ }^{132}$.

Vale também notar que a integração na petroquímica ocorre não apenas na forma vertical, mas também horizontal, sendo comuns operações de fusões e aquisições entre empresas que vendem produtos nos mesmos mercados, para obtenção de economias de escopo. Estas dizem respeito à redução de custos a partir da realização de atividades que, se reunidas sob uma mesma empresa, apresentam-se mais vantajosas do ponto de vista econômico do que se realizadas separadamente por empresas que atuam em um mesmo ramo. Seus efeitos se verificam não apenas na produção (como

\footnotetext{
129 Em sua obra The Economic Institutions of Capitalism, New York, Free Press, 1987, O. E. WILLIAMSON registra a existência de diferentes formas de coordenação da atividade econômica, explicando-as basicamente pela presença de incertezas. Os mercados idealizados pela teoria neoclássica mecanismos impessoais, descentralizados e espontâneos de formação de preços, onde interagem de forma perfeita indivíduos racionais movidos pelo auto-interesse - e as hierarquias - formas em que toda a produção é organizada internamente à firma - são os dois extremos "puros". A realidade, na prática, permite observar várias formas intermediárias, nas quais os atores continuam sendo autônomos, mas estabelecem entre si relações duráveis, ingressando em redes, por meio de sub-contratações, joint ventures, alianças estratégicas e cruzamento de participações acionárias, entre outros. A racionalidade limitada, o oportunismo e a especificidade dos ativos são fontes importantes de incerteza, e sua presença numa dada relação de intercâmbio demanda a adoção de uma destas diversas formas de coordenação, às quais, por sua vez, estão associados custos de transação de diferentes tipos e níveis.

${ }^{130}$ Cf. M. K. PERRY, apud A. LÓPEZ, Mercado y Estado en la Economía del Desarrollo, p. 47.

${ }^{131}$ Cf. G. R. SCHUTTE, Elo Perdido...op. cit., p. 54.

${ }^{132}$ Apud G. R. SCHUTTE, Elo Perdido...op. cit., p. 54.
} 
mencionado anteriormente, em razão da obtenção de subprodutos), mas também nas atividades de $\mathrm{P} \& \mathrm{D}$, comercialização, administração e financiamento.

\section{Intensidade Tecnológica}

Os processos de produção na petroquímica consistem basicamente em reações químicas realizadas em sistemas fechados, com uso de equipamentos e tubos dotados de rígidas especificações técnicas que lhes permitem operar sob condições críticas de temperatura, pressão e corrosão. São traços particulares da produção: a possibilidade de emprego diversificado de um mesmo processo para obtenção de vários produtos, mediante adições e/ou adaptações dos equipamentos existentes, e também a fabricação e o aproveitamento de subprodutos ${ }^{133}$.

A complexa tecnologia utilizada pode ser classificada em três grupos: a) a tecnologia central (engenharia de processo e básica), que envolve custo muito alto e no caso brasileiro é praticamente toda importada; b) a tecnologia periférica, destinada a detalhar e montar projetos básicos (engenharia de detalhe e montagem); e c) a tecnologia operacional (engenharia de fábrica, produto e aplicação) ${ }^{134}$.

Desde sua origem, a indústria petroquímica é considerada fortemente baseada no desenvolvimento científico (science-based), característica intensificada nas últimas décadas com o acirramento da competição ${ }^{135}$. Diante disso, as atividades de pesquisa e desenvolvimento (P\&D) visando promover inovações e aperfeiçoamentos tecnológicos têm tradicionalmente sido parte importante da estratégia empresarial no setor, na medida em que seus resultados podem contribuir para melhorar as escalas operacionais, reduzir custos e elevar a rentabilidade ${ }^{136}$.

O ritmo dessas inovações vem se diferenciando nas etapas da cadeia de produção petroquímica, sendo atualmente mais lento em relação aos produtos básicos (de primeira geração) e bem mais intenso nos produtos finais (sobretudo termoplásticos), o que torna ainda mais relevantes os investimentos em $\mathrm{P} \& \mathrm{D}$ nesse segmento.

133 Cf. S. A. F. CÁRIO, A Relação Público-Privada na Indústria Petroquímica Brasileira: da Estruturação Articulada à Reestruturação Incerta, Campinas, Universidade Estadual de Campinas, 1997, (Tese de Doutoramento apresentada ao Instituto de Economia), p. 15.

${ }^{134}$ M. A. SUAREZ, Petroquímica e Tecnoburocracia...op. cit., p. 38 e ss.

${ }^{135}$ Cf. G. R. SCHUTTE, Elo Perdido...op. cit., p. 58.

${ }^{136}$ Cf. S. A. F. CÁRIO, A Relação Público-Privada...op. cit., p. 18. 
As fontes detentoras das tecnologias empregadas na petroquímica são basicamente as empresas especializadas em engenharia, predominantemente de origem norte-americana, e as grandes corporações internacionais que atuam nas atividades química e petroquímica. $\mathrm{O}$ acesso a esses processos tecnológicos pelas demais empresas é dificultado, entre outros fatores, pelo alto custo envolvido e também pela exigência de haver um mínimo de estrutura e capacidade para absorção da nova tecnologia. Em virtude de tais complicações, as empresas dos novos países produtores acabam somente conseguindo implantar a produção petroquímica até os segmentos considerados "mais simplificados" e "mais baratos", denominados commodities e pseudocommodities ${ }^{137}$, tornando-se, portanto, importadores dos produtos mais complexos e de maior valor agregado, tal como ocorre com o Brasil e a Coréia do Sul ${ }^{138}$.

\section{Estrutura em oligopólio e padrão de concorrência}

Como resultado de suas características técnico-econômicas (fortes economias de escala e escopo, integração vertical e conglomeração, intensidade e especificidade tecnológica, entre outras), a configuração natural da indústria petroquímica é o oligopólio, dotado de importantes barreiras ao ingresso de novos concorrentes no mercado $^{139}$.

Em todos os países onde se implantou a petroquímica verificou-se essa estrutura de mercado, o que reflete também no desenho do mercado internacional de produtos petroquímicos. Neste último caso, o oligopólio tomou forma a partir do processo de reestruturação do setor ocorrido na década de 1980, que originou a formação de grandes empresas de atuação mundial (os chamados global players), envolvendo, sobretudo, empresas petrolíferas que avançaram à frente na cadeia e também grandes empresas químicas que diversificaram sua produção. Complementa ainda esse cenário

137 Denominam-se commodities os produtos considerados básicos, padronizados, dependentes de matérias-primas específicas e produzidos em larga escala. As pseudocommodities, por sua vez, englobam os produtos dotados de algumas especificações de desempenho, também dependentes de matéria-prima específica e fabricados em escala.

${ }^{138}$ Cf. G. R. SCHUTTE, Elo Perdido...op. cit., p. 62.

139 As barreiras à entrada na petroquímica podem ser decorrentes de elementos intrínsecos ao setor (barreiras endógenas), que independem das estratégias adotadas pelos atores envolvidos, ou externos (barreiras exógenas). No primeiro caso, incluem-se a exigência elevada de capital, economias de escala, diferenciação de produtos, $\mathrm{P} \& \mathrm{D}$, custos irrecuperáveis e integração vertical. No segundo, verifica-se a importância das decisões estratégicas tomadas pelos atores envolvidos, tanto empresas como o poder público, servindo de explicação tanto para o fato do grau de concentração das diversas indústrias ser aproximado nos países, como também para a existência de eventuais variações entre eles. Cf. G. R. SCHUTTE, Elo Perdido...op. cit., p. 56. 
internacional a presença de outras empresas de menor tamanho que atuam em mercados específicos e exploram vantagens tecnológicas ou de canais de distribuição ${ }^{140}$.

A dinâmica da concorrência no setor, por sua vez, apresenta-se de forma não uniforme, coexistindo segmentos produtivos com características de oligopólio concentrado e atividades dotadas de aspectos característicos de oligopólio diferenciado, segundo a classificação de M. L. Possas ${ }^{141}$.

Assim é que na produção de petroquímicos básicos e intermediários observa-se um oligopólio concentrado, pelas características relativamente homogêneas dos produtos (e pouco passíveis de diferenciação), pelo grande tamanho das unidades produtivas e sua concentração técnica, e pelo longo prazo de maturação dos investimentos nessas áreas. Por seu turno, a produção de petroquímicos finais apresenta estrutura de oligopólio diferenciado, tendo a diferenciação de produtos, por meio da permanente inovação (em termos de produtos, processos e técnicas de produção, entre outros) como traço preponderante.

Em função dessas peculiaridades atreladas à forma como se estrutura o oligopólio em cada segmento da produção, as estratégias de competição adotadas pelas empresas petroquímicas também diferem dependendo de sua inserção na cadeia. Em geral, na produção de $1^{\mathrm{a}}$ e $2^{\mathrm{a}}$ geração as estratégias empresariais são voltadas para o desenvolvimento tecnológico visando à obtenção de economias de escala. No que diz respeito à produção dos petroquímicos finais, as empresas priorizam a diferenciação de produtos, procurando lançar produtos novos, passíveis de aplicações variadas no mercado, dotados de melhor qualidade ou outros atributos antes inexistentes no $\operatorname{mercado}^{142}$.

\section{Capacidade ociosa, caráter cúclico dos preços e internacionalização}

Outra característica importante da petroquímica decorre da presença freqüente de problemas de capacidade ociosa, constatados por duas razões fundamentais. Em primeiro lugar, como já mencionado, a entrada em operação de uma planta petroquímica conduz ao crescimento descontínuo ("em saltos") da escala de produção, enquanto o mercado não evolui no mesmo ritmo. Em segundo lugar, os equipamentos e sistemas

\footnotetext{
${ }^{140}$ Cf. G. R. SCHUTTE, Elo Perdido...op. cit., p. 54.

${ }^{141}$ Ver M. L. POSSAS, Estruturas de Mercado em Oligopólio, São Paulo, HUCITEC, 1985, pp. 179-194.

${ }^{142}$ S. A. F. CÁRIO, A Relação Público-Privada...op. cit., p. 14 e 15.
} 
que compõem as plantas industriais são indivisíveis e condicionam um sistema contínuo de produção, impossibilitando a operação abaixo de um nível bastante elevado da capacidade instalada ${ }^{143}$. Conseqüentemente, há um permanente descompasso entre oferta e demanda dos produtos, o que terá reflexos importantes nos seus preços.

A presença de capacidade ociosa, aliada à alta dependência de matérias-primas específicas e ao padrão internacional de intensa competição oligopolista tende a produzir ciclos de investimentos, produção e preços. Durante a fase de alta - geralmente coincidente com momentos de crescimento das principais economias mundiais - há grandes investimentos em ampliações da capacidade produtiva, o que em três ou quatro anos resulta em excesso de oferta e conseqüente queda geral dos preços ${ }^{144}$.

Para contornar essa situação, freqüentemente as grandes empresas internacionais fixam preços de exportação que não cobrem os custos totais de produção, mas apenas os custos fixos. Criam, assim, uma situação de dumping estrutural, praticando preços de exportações inferiores aos do mercado interno ${ }^{145}$. Este fato tem conduzido a um grande aumento de ações antidumping nas instâncias de comércio internacional: dos 904 processos anti-dumping iniciados entre 1980 e 1990 na União Européia, por exemplo, $40 \%$ são relacionados à petroquímica ${ }^{146}$.

A trajetória internacional da indústria petroquímica fortemente marcada por crises de superprodução, somada a suas especificidades técnico-econômicas, implicou importantes reestruturações, em nível mundial, na forma de organização do setor. Como já mencionado, a primeira delas ocorreu na década de 1980, em decorrência das respostas estratégicas adotadas pelas empresas aos choques do petróleo: corte de custos em mão-de-obra, racionalização do uso de energia e a busca de maior integração, especialização e descentralização geográfica da produção. Nessa fase, conforme salienta G. R. Schutte, governos de países europeus, do Japão e mesmo dos Estados Unidos deliberadamente abriram mão de uma aplicação rigorosa das leis antitruste, dando primazia à necessidade de favorecer os processos de concentração como instrumento para combater o problema da superprodução ${ }^{147}$.

\footnotetext{
143 Idem, p. 21 e 22. Segundo indica A. LÓPEZ, em referência a F. CHESNAIS, considera-se a necessidade de ocupação de $82 \%$ da capacidade instalada como sendo o patamar mínimo de rentabilidade na petroquímica. Mercados, coordinación...op. cit., p. 55.

${ }^{144}$ Cf. G. GOMES et. al., Indústria Petroquímica Brasileira: Situação Atual e Perspectivas, BNDES Setorial, Rio de Janeiro, n. 21, pp. 74-104, março-2005, p. 78.

${ }^{145}$ Cf. F. ERBER, Desarrollo y Reestructuración de la Petroquímica Brasileña in Auge y Ocaso...op. cit., p. 162.

${ }^{146}$ Cf. G. R. SCHUTTE, Elo Perdido...op.cit., p. 55.

${ }^{147}$ Idem, p. 75.
} 
A segunda importante reestruturação na indústria petroquímica mundial verificou-se no início dos anos 1990, em virtude do baixo crescimento econômico dos países centrais e da entrada de novos produtores no mercado (países do leste asiático e produtores de petróleo do Extremo Oriente $)^{148}$. Neste caso, materializou-se o processo de reestruturação em uma grande onda de aquisições de empresas, com forte caráter acionário, além da criação de novas companhias reunindo ativos de empresas distintas já existentes (fusões). Tais estratégias empresariais visaram obter integração em nível global, aumentar as escalas empresariais, conquistar acesso a novas tecnologias e a novos canais de distribuição, assim como promover o desinvestimento em áreas não mais consideradas vantajosas ${ }^{149}$.

Deste movimento resultou a consolidação das grandes empresas transnacionais do setor petroquímico e o acirramento da competição entre elas, em nível global, acentuando-se também o já elevado grau de internacionalização da produção e comercialização, característico da petroquímica. A organização da produção estruturada em torno das mega-corporações está diretamente relacionada à intensidade do fluxo de comércio internacional dos produtos petroquímicos. A localização estratégica dessas grandes empresas nos principais centros econômicos - em função do seu potencial de demanda e nível de renda elevado - permite que se tornem responsáveis pelo abastecimento de um número ainda maior de mercados ${ }^{150}$.

Pelo exposto até aqui, pode-se concluir na mesma direção apontada por D. Chudnovsky e A. López, para quem a petroquímica se caracteriza fundamentalmente pela presença de elementos aos quais o paradigma de mercado neoclássico tende a dar pouca atenção, a saber: exigência de investimentos elevados em $P \& D$, indivisibilidades, especificidade de ativos, economias de escala e conglomeração, além de estrutura oligopolizada em nível mundial ${ }^{151}$.

Em face desses elementos, o mercado perfeitamente competitivo corresponde a uma construção teórica que, na realidade, é substituída por formas alternativas de coordenação, tanto hierárquicas (via integração vertical, contratos entre partes independentes e redes), como cooperativas (acordos de divisão de mercado e de

\footnotetext{
${ }^{148}$ Idem, ibidem.

${ }^{149}$ Idem, p. 93.

150 Segundo O. GUERRA constata-se que o fluxo de investimentos diretos da indústria químicapetroquímica tem sido predominantemente entre países industrializados, e não entre estes e as economias em desenvolvimento. Apud S. A. F. CÁRIO, A Relação Público-Privada...op. cit., p. 29.

${ }^{151}$ Auge y Ocaso del Capitalismo Asistido: La Industria Petroquímica Latinoamericana, Santiago de Chile, Cepal/IDRC/Alianza Editorial, 1997, p. 17 e ss.
} 
intercâmbio de tecnologia) e cuja complexidade induz ao envolvimento dos estados nacionais $^{152}$.

Como resultado, o setor petroquímico tem historicamente contado com variados mecanismos de atuação estatal, tanto nos países industrializados como nos países em desenvolvimento. Em muitos casos (a exemplo da França, Itália, Holanda, Coréia do Sul, México e Venezuela) o Estado participa diretamente da indústria, possuindo controle total ou parcial sobre as empresas produtoras. Em outras situações, mesmo não sendo produtor o Estado se envolve por meio da regulação da indústria, por exemplo, delimitando as condições de oferta de matérias-primas ou então se valendo de instrumentos de apoio, como os mecanismos fiscais e creditícios de estímulo aos investimentos e às exportações; de coordenação, como no caso do Ministério de Indústria e Comércio japonês; e de prevenção e repressão ao abuso de poder econômico, por meio da disciplina jurídica da concorrência, de mecanismos de defesa comercial e de proteção do meio-ambiente ${ }^{153}$.

A partir dos anos 1990, sob influência da concepção de desenvolvimento que se tornou hegemônica, observa-se uma mudança no regime de regulação da indústria petroquímica, no Brasil e no mundo, ampliando e fortalecendo a coordenação do setor via mercado. Para tanto, ao Estado cumpriria desarticular o complexo arcabouço regulatório do regime anterior, além de prover mecanismos que assegurassem o melhor funcionamento dos mercados, como é o caso da disciplina antitruste, prevenindo e coibindo eventuais abusos ${ }^{154}$.

Um pouco mais adiante, a seção 3 reconstitui esse percurso da regulação para o caso brasileiro, para então aprofundar a análise da aplicação do direito da concorrência no setor petroquímico. Em primeiro lugar, entretanto, visita-se brevemente a trajetória da indústria petroquímica no país, desde a sua constituição, até a atualidade, dando-se destaque às especificidades da organização do setor no Brasil em relação ao padrão internacional. Pretende-se, assim, oferecer um panorama acerca das condições materiais em que se encontrava a indústria nacional quando da mudança no arcabouço regulatório, e também do pano de fundo que ensejou a submissão de um número tão

\footnotetext{
${ }^{152}$ F. ERBER, Desarrollo y Reestructuración...op. cit., p. 163.

${ }^{153}$ Cf. F. ERBER, Desarrollo y Reestructuración...op. cit., p. 163. Cumpre aqui reproduzir a observação do autor, de que "de forma mais indireta, em todos os países o Estado afeta a competitividade sistêmica das indústrias locais mediante a provisão de infra-estrutura econômica e tecnologia, e por meio de políticas fiscais, de câmbio e de educação".

${ }^{154}$ F. S. ERBER e J. C. de OLIVEIRA, A Indústria Petroquímica...op. cit., p. 8.
} 
expressivo de atos de concentração ao Sistema Brasileiro de Defesa da Concorrência a partir da segunda metade dos anos 1990.

\section{As especificidades da indústria petroquímica no Brasil}

No Brasil, a implantação da indústria petroquímica ocorreu na década de 1960, sob intensa atuação estatal empreendida com foco no objetivo central de completar o processo de substituição de importações, além de diminuir a dependência externa e contribuir para a formação de um empresariado no setor ${ }^{155}$.

Os pólos petroquímicos foram instalados em São Paulo (1965/72), Camaçari/Bahia (1972/78) e Triunfo/Rio Grande do Sul (1978/82), sendo constituídos principalmente por empresas de primeira e segunda geração. Tais empreendimentos se realizaram no marco de um modelo empresarial tripartite, assim denominado por contar com participações do Estado, do capital nacional e do capital estrangeiro.

A configuração da estrutura empresarial brasileira, quando comparada ao ambiente internacional da petroquímica, apresenta notáveis especificidades. Estas são decorrentes tanto da peculiar forma de constituição desta indústria no país, como também do especial contorno assumido pelo arcabouço regulatório que durante muitos anos gerenciou o setor ${ }^{156}$.

Assim é que, em contraste com os padrões internacionais anteriormente apresentados, a petroquímica brasileira não dispõe de estrutura suficientemente integrada verticalmente, as empresas apresentam escalas pequenas (em termos de faturamento) e a produção é concentrada na fabricação de bens relativamente padronizados - commodities e pseudocommodities - e de menor valor agregado. As características de estrutura do setor, somadas à natureza monoprodutora das empresas e o seu baixo faturamento, por sua vez, desdobram-se na limitação dos gastos em tecnologia, o que torna lento o ritmo das inovações na petroquímica nacional ${ }^{157}$.

O baixo grau de integração entre as firmas pode ser visualizado na cadeia de produção: a matéria-prima (nafta) é produzida sob o monopólio da Petrobrás; os petroquímicos básicos são produzidos por empresas isoladas (as centrais); e os demais

\footnotetext{
155 Objetivos explicitados no II PND, que coloca ênfase em bens de produção.

${ }^{156}$ F. ERBER, Desarrollo y Reestructuración ...op. cit., p. 214.

${ }^{157}$ F. ERBER e R. VERMULM, Os Determinantes Estruturais...op. cit., pp. 107-118.
} 
petroquímicos (as resinas termoplásticas, por exemplo) são fabricados por várias empresas, em geral pequenas e monoprodutoras ${ }^{158}$.

Essa falta de integração é em grande medida originária do modelo empresarial tripartite, sob o qual se constituiu parte majoritária dos empreendimentos petroquímicos no país. Nesse modelo, as participações acionárias dos grupos empresariais nacionais e estrangeiros acabaram se estabelecendo de forma fragmentada e cruzada ao longo da cadeia e mesmo no âmbito das empresas. O controle compartilhado sob estas últimas, por sua vez, contribuiu para que os acordos de acionistas - em que há previsão de poder de veto - adquirissem peso importante nos processos de tomada de decisões estratégicas nas firmas.

Desse fenômeno resulta a conformação de um ambiente bastante complexo para a tomada de decisões pelas empresas e grupos. A dependência de uma intrincada composição de interesses, muitas vezes inconciliáveis, por vezes acaba dificultando o processo de integração e conglomeração no setor, obstruindo a conformação de economias de escopo mais significativas e outras vantagens competitivas correlatas.

A figura apresentada a seguir representa o grau de integração das firmas brasileiras em comparação a outros países ${ }^{159}$ :

158 Cf. O. F. GUERRA. Estrutura de Mercado e Estratégias Empresariais: O Desempenho da Petroquímica Brasileira e suas Possibilidades Futuras de Inserção Internacional, Brasília, SESI-DN, 1994.

${ }^{159}$ Extraída do parecer SEAE no Ato de Concentração n. ${ }^{\circ}$ 08012.005799/01-92. É anterior, portanto, à constituição do pólo Gás-Rio e às operações realizadas em 2007. 


\section{Quadro Comparativo do Grau de Verticalização da Indústria Petroquímica em Ámbito Global}

\begin{tabular}{|c|c|c|c|c|}
\hline PAÍSES & $\begin{array}{c}\text { EXPLORAÇÃO } \\
\text { PETRÓLEO }\end{array}$ & $\begin{array}{l}\text { PETROQUÍMICOS } \\
\text { BÁSICOS }\end{array}$ & $\begin{array}{c}\text { PRODUTOS } \\
\text { FINAIS } \\
\text { PETROQUIMICOS }\end{array}$ & $\begin{array}{l}\text { QUIMICA FINA E } \\
\text { ESPEC. }\end{array}$ \\
\hline \multirow{3}{*}{ BRASIL } & PFTRORRÁS & CENTRAIS & Unidades de $2^{\mathrm{a}}$ gera- & \multirow{2}{*}{ 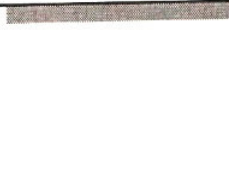 } \\
\hline & BASELL EXXOI & BIL CHEVRON/P & S BP & \\
\hline & DUPONT & & & \\
\hline \multirow[t]{3}{*}{ ESTADOS UNIDOS } & & \multicolumn{2}{|c|}{ DOW/UCC EASTMAN EQUISTAR } & \\
\hline & & & HUNTSMAN & \\
\hline & & & \multicolumn{2}{|l|}{ MONSANTO } \\
\hline GRA-BRETANHA & \multicolumn{4}{|l|}{ BP BASELL } \\
\hline \multirow[t]{4}{*}{ FRANÇA } & \multicolumn{2}{|l|}{ ATOFINA } & & RHONE POULENC \\
\hline & DEGUSSA-HUL & & & \\
\hline & $\mathrm{BP}$ & & & \\
\hline & BAYER & & & \\
\hline \multirow[t]{4}{*}{ ALEMANHA } & SHELL & SOLVAY - BASF & & \\
\hline & URBN & & \multicolumn{2}{|l|}{ HOESCHST } \\
\hline & & \multicolumn{2}{|c|}{ DOW CENTRAL GERMANY } & \\
\hline & \multicolumn{3}{|l|}{ BASELL } & \\
\hline ARGENTINA & DOW & & & \\
\hline \multirow{2}{*}{ JAPÄO } & \multicolumn{3}{|c|}{ IDEMTISU PETROLEUM EDEMITSU PETROCHEMICAL } & \\
\hline & & MITSUBISHI KAS & ITSUBICHI PETRO & MICAL \\
\hline \multirow{2}{*}{ CORĖIA DO SUL } & & \multicolumn{2}{|l|}{ HANWAH/DAELIM } & \\
\hline & & \multicolumn{2}{|c|}{ SAMSUNG HYUNDAI } & \\
\hline \multirow[t]{2}{*}{ MÉXICO } & \multicolumn{2}{|l|}{ PEMEX } & & \\
\hline & & CYDSA IDESA PC & LES & \\
\hline
\end{tabular}


A ausência de diversificação da produção é outra característica da indústria brasileira que não acompanhou a trajetória internacional da petroquímica em direção a produtos mais diferenciados e de maior valor agregado, tais como especialidades, plásticos de engenharia e química fina ${ }^{160}$. Fator determinante no caso brasileiro diz respeito às dimensões da indústria doméstica: embora as plantas apresentem porte internacional, as empresas e grupos têm escalas pequenas em volume de faturamento. Por essa razão, resultam incapazes de promover um adequado nível de investimentos em tecnologia, pesquisa e desenvolvimento, caracterizando-se assim sua baixa propensão à inovação.

Estes problemas do modelo empresarial, segundo F. S. Erber e J. C. de Oliveira, não passavam despercebidos na fase inicial da conformação da indústria. Esperava-se, contudo, que seriam equacionados mais adiante, através de processos de aglutinação empresarial. Além disso, no curto prazo, a proteção contra as importações, o baixo grau de intensidade da concorrência, a grande expansão no mercado interno e a própria "juventude" do pólo de Camaçari (criado sob o arranjo tripartite) dava condições para que sua solução fosse postergada ${ }^{161}$.

Em que pesem referidas particularidades, a literatura que aborda a evolução da petroquímica brasileira e de seu desempenho aponta que o modelo empresarial nacional funcionou relativamente bem até meados da década de 1980, fortemente amparado pela atuação do Estado. O complexo arcabouço regulatório desenhado incluía diversos instrumentos ${ }^{162}$ que, em conjunto, resultaram capazes de levar a produção nacional a assumir um posicionamento importante no cenário econômico mundial. Segundo relata C. Parisi Jr., partindo-se de um parque petroquímico bastante incipiente, a indústria brasileira conseguiu se situar entre as dez maiores do mundo em sua categoria ${ }^{163}$. Desse modo, no período que se estende da constituição do setor no país até 1991, foi possível constatar taxas elevadas de crescimento e lucratividade para as empresas atuantes na petroquímica.

O passado recente, entretanto, evidencia que esse quadro de excepcional desempenho sofreu profunda alteração. Houve queda acentuada da rentabilidade das empresas, vendas cadentes em alguns anos, ocupação de parcela crescente do mercado

\footnotetext{
${ }^{160}$ F. ERBER e R. VERMULM, Os Determinantes Estruturais...op. cit., p. 108.

${ }^{161}$ Cf. A Indústria Petroquímica Brasileira...op. cit., p. 15.

162 Entre os mecanismos regulatórios existentes, podem ser mencionados: a) a reserva de mercado; b) a política de preço especial para a nafta; c) quotas de fornecimento de matérias primas para produtores downstream; e d) o controle de preços ao longo de toda a cadeia produtiva.

${ }^{163}$ Cf. PARISI JR., O Problema da Competitividade...op. cit., p. 7.
} 
doméstico por importações e diminuição dos preços de várias commodities petroquímicas nos mercados internacionais nos últimos anos, com o que se delineou um cenário de crise no setor ${ }^{164}$.

Entre as causas dessa crise, aponta-se a ruptura com o arcabouço regulatório que esteava a petroquímica brasileira na década de 1980. Em um cenário de crise econômica interna e também internacional ${ }^{165}$, a substituição dos instrumentos estatais de apoio e incentivo à indústria por medidas visando ampliar os contornos e o domínio dos mercados - abertura, liberalização, privatizações e desregulação - tiveram como principal efeito explicitar as fragilidades e limitações inerentes ao modelo nacional de firmas fragmentadas, especializadas e monoprodutoras ${ }^{166}$.

Dada a sua importância, no tópico a seguir são explorados os principais aspectos pertinentes ao envolvimento do Estado brasileiro na petroquímica e à evolução dos mecanismos de regulação estatal no setor.

\section{Os mecanismos de regulação estatal na indústria petroquímica brasileira em perspectiva histórica}

A história da indústria petroquímica brasileira confunde-se com a história de seus mecanismos de regulação. Desde a sua origem, a petroquímica nacional contou com uma peculiar composição entre o setor público e o privado, em que ao Estado coube um papel de destaque, pelo seu caráter estruturante.

Na implantação da indústria, o Estado atuou diretamente no domínio econômico, por meio da Petroquisa (empresa estatal subsidiária da Petrobrás e acionista nos empreendimentos petroquímicos); e indiretamente, por meio da regulação do mercado, articulando uma multiplicidade de instrumentos redutores de riscos e incertezas para os

\footnotetext{
${ }^{164}$ Idem.

${ }^{165}$ Neste caso em virtude da sobreoferta de produtos ocasionada pela entrada de novos players (países do Extremo Oriente) no mercado internacional de produtos petroquímicos.

166 A síntese das fragilidades da petroquímica brasileira, no contexto econômico internacional é apresentada por O. F. GUERRA nos seguintes termos: a) incapacidade para atingir escalas, faturamento e "massa crítica" necessários para a efetivação de gastos regulares e em montantes adequados em P\&D inviabilizando o desenvolvimento de inovações tecnológicas; b) impossibilidade de obter economias de escopo - as sinergias intrasetoriais, que se constatam nas grandes firmas químicas/petroquímicas internacionais não se verificam no Brasil, na medida em que as empresas elaboram produtos específicos; c) dificuldade de oferecer respostas empresariais às flutuações cíclicas da economia e a movimentos de reestruturação/racionalização que envolvam ajustes de capacidade produtiva através de fechamento de fábricas - isso significaria desativar uma empresa, na medida em que ela é monoprodutora; e d) multiplicidade de custos administrativos, comerciais e tributários - custos de overhead das empresas brasileiras são elevados em relação a competidores internacionais. Estrutura de Mercado...op. cit., p. 284.
} 
particulares. Não apenas a implantação, mas também a operacionalização da petroquímica contou com a coordenação estatal, neste caso responsável pela fixação dos preços e estabelecendo barreiras à importação para proteger o mercado interno ${ }^{167}$.

F. Erber e R. Vermulm identificam basicamente quatro etapas na evolução da indústria petroquímica nacional e de seu arcabouço regulatório ${ }^{168}$. A primeira abrange o período que vai de meados da década de 1950 até meados da década de 1960, quando são realizados os primeiros investimentos no setor e permanece ainda indefinido o arcabouço institucional. A segunda etapa é marcada pela implantação dos três pólos petroquímicos, em São Paulo (1965/72), Camaçari/BA (1972/78) e Triunfo/RS (1978/82), e pela consolidação do regime de regulação. No período subseqüente, que se estende até o fim da década de 1980, observa-se o amadurecimento da indústria e o início da deterioração da regulação. Por fim, na primeira metade dos anos 1990, registra-se uma fase de crise econômica e também da regulação do setor petroquímico nacional.

Em trabalho mais recente, F. S. Erber e J. C. de Oliveira fazem referência ao período mais atual da indústria no país, tratando do reposicionamento estratégico das empresas desde o final dos anos noventa até o presente, à luz do predomínio da regulação antitruste sobre os antigos mecanismos de atuação estatal, tema ao qual se dedica o próximo capítulo.

\section{$1^{a}$ Etapa: Primeiros investimentos e indefinição institucional}

Entre meados da década de 1950 e meados da década de 1960 são realizados os primeiros investimentos no setor petroquímico, ainda sob um arcabouço institucional indefinido. A Lei $\mathrm{n}^{\mathrm{o}} 2.004 / 53$, que cria a Petrobrás, trazia ambigüidade quanto à extensão do monopólio do petróleo, provocando dúvidas sobre a atividade petroquímica caberia ao Estado, à iniciativa privada, ou a ambos ${ }^{169}$. O impasse prevaleceu até meados da década de 1960, período durante o qual os investimentos no setor se concentraram predominantemente em produtos finais, tendo como origem, sobretudo, as empresas filiais de multinacionais ${ }^{170}$.

\footnotetext{
${ }^{167}$ Idem, p. 64 e ss.

${ }^{168}$ Idem, p. 68.

${ }^{169}$ Cf. C. PARISI JR., O Problema da Competitividade...op. cit., p. 21.

${ }^{170}$ Idem, p. 78.
} 
A partir de 1957, autoriza-se a atuação da Petrobrás para garantir o suprimento de matérias-primas básicas e produtos essenciais, tomando forma uma divisão de tarefas entre o Estado e a iniciativa privada que mais tarde seria consolidada. Nessa fase, a participação de capitais privados nacionais é praticamente inexistente ${ }^{171}$.

\section{$2^{a}$ Etapa: Constituição da indústria e do regime de regulação}

No período que se estende entre meados da década de 1960 e o início da década de 1980, ocorre a implantação sucessiva dos três pólos petroquímicos do país: em São Paulo (1965/72), Camaçari/Bahia (1972/78) e Triunfo/Rio Grande do Sul (1978/82). Sob forte orientação e presença direta do Estado, incentivando e regulando a indústria, configura-se um arcabouço institucional específico e complexo, em processo de amadurecimento.

Em 1964, os incentivos aos projetos de investimentos na petroquímica passaram a depender da aprovação formal do Estado, por meio de seu Conselho de Desenvolvimento Industrial (CDI), e do grupo executivo de representantes da indústria química (GEIQUIM). Este último subordinado ao primeiro e, aquele, ao Ministério da Indústria e Comércio. Ao CDI cabia decidir quais projetos seriam implantados ou, em outras palavras, quais atores seriam titulares dos empreendimentos petroquímicos, razão pela qual constituía o locus de articulação do aparato regulatório.

Os incentivos para a petroquímica, passíveis de aprovação pelo CDI/GEIQUIM incluíam:

a) Isenção do Imposto de Importação (II) e do Imposto sobre Produtos Industrializados (IPI) para os equipamentos que não possuíssem similar nacional;

b) Eventual elevação da alíquota incidente sobre a importação do produto a ser fabricado no país, quando indispensável à viabilização da Indústria Nacional;

c) Redução da alíquota incidente sobre matérias-primas, quando comprovadamente indispensáveis à execução e à operação dos projetos aprovados;

d) Redução da incidência do Imposto de Renda no período inicial de operação, pela aplicação de taxas de depreciação acelerada,

\footnotetext{
${ }^{171}$ Idem, Ibidem.
} 
anteriormente prevista na legislação e posta em vigor com o Decreto no 54.298/64;

e) Financiamento, aval e garantia por estabelecimentos oficiais de crédito, quando o interesse do projeto assim o justificasse, ou quando a empresa não pudesse recorrer a outras fontes de recursos;

f) Facilidade para a importação de equipamentos sob a forma de investimento direto ou sob financiamento do exterior; e

g) Redução de até $50 \%$ do valor do imposto de importação para equipamentos que fossem importados ${ }^{172}$.

À medida que foi se desenvolvendo e ampliando o aparato regulatório, também passou a haver maior definição sobre as atribuições do Estado e da iniciativa privada no setor petroquímico. Assim, em 1965, o Decreto n 56.571 estabeleceu que a atividade petroquímica não seria objeto do monopólio do petróleo, ficando a cargo da iniciativa privada a sua exploração econômica, com a recomendação de dar preferência ao capital nacional quando em igualdade de condições com o capital estrangeiro ${ }^{173}$.

Surgem então dois projetos de empreendimentos petroquímicos para o Brasil. O primeiro, anunciado pelo grupo norte-americano Union Carbide, não pôde ser levado adiante por falhas na concepção da tecnologia inovadora que se tencionava adotar. $\mathrm{O}$ segundo, de iniciativa do grupo Capuava (de origem nacional), pretendia a construção de uma central de eteno, a Petroquímica União - PQU. A exigência de elevado volume de investimentos, somada à alta complexidade tecnológica do empreendimento levou o grupo nacional a procurar outros parceiros: um estrangeiro, a Phillips Petroleum (com experiência tecnológica), e dois nacionais, o Moreira Sales e o Ultra, que contribuiriam para o maior aporte de capitais ${ }^{174}$.

A implantação da PQU, contudo, enfrentou uma série de dificuldades: à inexperiência nacional na área e ao aumento dos custos do projeto, por razões adversas, veio se somar a retirada do grupo estrangeiro. Diante da crise que quase inviabilizou a construção da primeira central petroquímica brasileira, teve início um processo de articulação para o envolvimento da Petrobrás no empreendimento.

Entretanto, a Lei $n^{\circ} 2.004 / 53$ que criara a empresa estatal não lhe facultava a possibilidade de associação com outros grupos econômicos. Diante desse fato, em 1968,

\footnotetext{
${ }^{172}$ Cf. C. PARISI JR., O Problema da Competitividade...op. cit.,, p. 23 e 24.

${ }^{173}$ Idem, p. 25.

${ }^{174}$ Idem.
} 
retira-se tal empecilho por meio da criação da Petrobrás Química S. A. - Petroquisa uma empresa subsidiária da Petrobrás autorizada a se associar a outros grupos empresarias para o desenvolvimento da indústria petroquímica no Brasil ${ }^{175}$. A partir de então, a Petroquisa passaria a ter atuação direta na estruturação do setor. Em parceria com o grupo Capuava, viabilizou a construção da central PQU, tendo também participação na constituição das empresas de segunda geração - organizadas sob o modelo tripartite - conformando-se assim o primeiro pólo petroquímico do Brasil em São Paulo.

Em 1971, quando da decisão de expandir a indústria nacional e construir um segundo pólo petroquímico (em Camaçari, na Bahia), consolida-se a utilização do modelo acionário tripartite. Sob esse arranjo, exigia-se o atendimento a algumas regras básicas. Em primeiro lugar, a central de matérias-primas - COPENE - ficaria sob controle da Petroquisa (empresa estatal), que contaria com pouco mais de $50 \%$ das ações ordinárias. As ações remanescentes permaneceriam pulverizadas entre as empresas de segunda geração. Estas, por seu turno, teriam composição tripartite capital nacional majoritário e participação da Petroquisa não inferior a dos sócios estrangeiros, sendo que nenhuma parte poderia sozinha deter maioria das ações.

Além da presença direta na atividade petroquímica viabilizada pelo sistema tripartite, o Estado também expandiu, indiretamente, sua participação nos investimentos do setor, facilitando as condições de financiamento e estabelecendo linhas de crédito via Banco Nacional de Desenvolvimento Econômico e Social (BNDES) e Finep.

Em 1976, no âmbito do II Plano Nacional de Desenvolvimento (PND) o governo Geisel decide implantar um terceiro pólo petroquímico no país, em Triunfo, no Rio Grande do Sul. Em virtude da deterioração das condições financeiras do Estado, que já nessa época dava sinais, observa-se neste caso menor ênfase na sua participação como investidor direto do empreendimento. Desse modo, o novo pólo inicia sua operação em 1982 com uma escala empresarial bastante inferior à dos predecessores. Ainda assim, a propriedade da central de matérias-primas do novo pólo, a Companhia Petroquímica do Sul S.A. - COPESUL assume caráter exclusivamente estatal (da Petroquisa e do BNDES, via BNDESPAR), constituindo-se neste caso outra diferença importante ${ }^{176}$.

Em contrapartida, com o agravamento da crise econômica interna e externa no início dos anos 1980, amplia-se a atuação pública na promoção de apoio e incentivos à

\footnotetext{
${ }^{175}$ Idem, p. 26.

${ }^{176}$ F. S. ERBER e J. C. de OLIVEIRA, A Indústria Petroquímica...op. cit., p. 16.
} 
exportação de produtos petroquímicos. Entre as medidas contidas nessa política incluem-se, em linhas gerais, acordos de exportação com a CACEX, por meio da concessão de subsídios e incentivos fiscais; acordos com a INTERBRÁS (subsidiária da Petrobrás para atuar como trading da petroquímica); atuação da Petroquisa como árbitro do processo de formação de preços e fixação das margens de lucro ao longo da cadeia produtiva, para permitir que a parcela da produção de petroquímicos finais destinados às exportações alcançasse preços mais competitivos.

Ao lado destas medidas específicas voltadas para facilitar as exportações, outros dois instrumentos regulatórios completavam o complexo arcabouço institucional que viabilizaria a atividade petroquímica no país no início dos anos 1980: o controle de preços dos produtos petroquímicos, sob responsabilidade do Conselho Interministerial de Preços - CIP, e a política de fixação de preços para a nafta (matéria-prima da petroquímica), comandada pela Petrobrás.

Em síntese, observa-se que a atuação do Estado brasileiro na estruturação e coordenação do mercado petroquímico exigiu um arcabouço regulatório que lhe permitiria desempenhar simultaneamente uma série de funções, tais como a de planejador, ordenador, financiador e proprietário. Esse complexo sistema de coordenação exerceu grande influência na definição estratégica das empresas e, conseqüentemente, refletiu sobre seu comportamento e performance ${ }^{177}$.

Os mecanismos de regulação estatal na petroquímica brasileira e as respectivas instituições responsáveis pela sua coordenação são sintetizados no quadro a seguir ${ }^{178}$ :

${ }^{177}$ S. A. F. CÁRIO, A Relação Público-Privada...op. cit., p. 3.

178 Fonte: F. ERBER e R. VERMULM, Os Determinantes Estruturais...op. cit., p. 107. 


\section{Regulação Estatal no Setor Petroquímico Brasileiro}

1) Mecanismos redutores de incerteza do investimento

1.1) Proteção contra importações - Cacex e CPA

1.2) Seleção de participantes do setor - CDI

1.3) Fornecimento de matérias-primas - Petrobrás (nafta) e Petroquisa (centrais de pólos)

1.4) Aportes de capital de risco - Petroquisa, BNDES e Finor

1.5) Escolha de tecnologia - Petroquisa

2) Mecanismos redutores de custo de investimento

2.1) Crédito favorecido para capital fixo - BNDES

2.2) Crédito para atividades tecnológicas - Finep

2.3) Apoio técnico para implantação de fábricas e atividades tecnológicas Petroquisa e Petrobrás

2.4) Incentivos fiscais para equipamentos nacionais e importados - CDI

3) Mecanismos redutores de custo de operação

3.1) Preço da nafta - Petrobrás

3.2) Incentivos fiscais - isenção de imposto de renda (Bahia), crédito de imposto de circulação de mercadorias (Bahia) e depreciação acelerada (todos)

4) Mecanismos de apoio à exportação

4.1) Preços diferenciados - Petroquisa, Petrobrás

4.2) Incentivos fiscais - Befiex

4.3) Comercialização - Interbrás/Petrobrás

5) Pressões para realização de atividades tecnológicas no país

5.1) Na contratação de tecnologia importada - INPI

5.2) Na concessão de crédito - BNDES

5.3) Diretamente - Petroquisa 
Um rápido balanço a respeito do arcabouço regulatório acima descrito não poderia deixar de apontar para alguns dos resultados importantes obtidos durante os anos 1980: em primeiro lugar, a montagem e consolidação de três pólos petroquímicos em um intervalo de tempo consideravelmente reduzido (aproximadamente quinze anos). Além disso, o bom desempenho econômico das firmas nacionais e o posicionamento do país entre os dez maiores produtores do mundo. Por fim, o fato das alianças entre o capital nacional e estrangeiro, lideradas pela Petroquisa, terem possibilitado a formação de um empresariado petroquímico profissional e a aquisição/absorção de uma considerável capacitação tecnológica ${ }^{179}$.

Por outro lado, do ponto de vista societário, esse processo de constituição da indústria e do seu arcabouço institucional deixavam em aberto algumas questões fundamentais. Em particular, sob o complexo regime de regulação estatal delineado nesta etapa, a Petrobrás tornara-se o principal ator da indústria. Além de desempenhar função decisiva no monopólio do suprimento da matéria-prima utilizada (nafta), tornara-se sócia nas empresas através da Petroquisa - com participação majoritária nas centrais, e minoritária na maioria das empresas de segunda geração em que capitais privados nacionais tomavam parte ${ }^{180}$. Essa estrutura contribuiu para que a Petroquisa obtivesse uma visão do todo em relação à cadeia de produção petroquímica, e para que fortalecesse sua capacidade de articulação política ${ }^{181}$.

Assim, aparentemente, a Petrobrás teria condições de liderar a estratégia para o setor, embora tivesse que negociá-la com uma pluralidade de atores importantes. Entretanto, o critério eleito para conduzir a implantação da indústria - o controle privado das empresas, mesmo que aplicado principalmente nas firmas de segunda geração - impediria que a Petrobrás concretamente exercesse sua potencial hegemonia. Referido critério, cuja materialização se dava nos acordos de acionistas, proporcionava poder de veto aos sócios do arranjo tripartite, acarretando bloqueios nas estratégias dos participantes e obrigando-os a renovar permanentemente os acertos entre eles. Em conseqüência, como afirmam F. Erber e J. C. Oliveira, "a capacidade estratégica da

\footnotetext{
${ }^{179}$ A avaliação está presente em C. PARISI JR., O Problema da Competitividade...op. cit., p. 33.

${ }^{180}$ F. S. ERBER e J. C. de OLIVEIRA, A Indústria Petroquímica...op. cit., p. 17.

${ }^{181}$ F. ERBER e R. VERMULM, Os Determinantes Estruturais...op. cit., p. 83.
} 
Petroquisa era substancialmente menor do que aparentava ser, mas tampouco a estratégia era passível de ser definida pelos sócios privados" ${ }^{182}$.

Diante das dificuldades impostas pelos arranjos societários na petroquímica, as empresas privadas não ficaram passivas ${ }^{183}$ e passaram a buscar se fortalecer. Contudo, paralelamente a esse movimento inicia-se um processo de progressiva desarticulação e conseqüente enfraquecimento do arcabouço regulatório estatal, conforme abordado a seguir.

\section{$3^{a}$ Etapa: Amadurecimento da Indústria e Deterioração da Regulação}

A tendência de fortalecimento do empresariado privado nacional, na petroquímica, começa a ser observada em 1980, quando as empresas de segunda geração do pólo de Camaçari que detinham ações da central de matérias-primas (Copene) constituíram uma holding, a Nordeste Química S.A. (Norquisa), a quem transferiram as respectivas ações, passando a representar, no conjunto, uma participação de 47,2\% no seu capital votante. Tal participação era equivalente à da Petroquisa, que detinha o correspondente a 48,1\%. Entre 1978 e 1985, a participação do Estado no capital do pólo de Camaçari como um todo reduziu de $42 \%$ para $38 \%$, diferença que foi tomada pelo empresariado nacional ${ }^{184}$.

Outro dado relevante é a ampliação das atividades petroquímicas do Grupo Odebrecht, sobretudo por meio de aquisições acionárias, constituindo-se no principal grupo privado nacional. Esse fato, aliado ao processo de retirada dos sócios estrangeiros e conseqüente "nacionalização" das joint-ventures tripartites no curso da década de 1980, dá conta do relativo amadurecimento do empresariado nacional, num contexto, como já mencionado, de crescente desarticulação do aparato regulatório estatal para o setor $^{185}$.

No início dos anos 1980, o cenário econômico interno de crescente endividamento, agravado pelo segundo choque do petróleo, alterou o quadro de demanda crescente para os produtos petroquímicos. Como tentativa de superar as

\footnotetext{
182 A Indústria Petroquímica...op. cit., p. 18.

${ }^{183}$ Idem.

${ }^{184}$ Idem.

${ }^{185}$ Idem.
} 
condições econômicas negativas, as empresas nacionais passaram a buscar como estratégia uma maior inserção internacional, privilegiando as exportações. Para tanto, a petroquímica contou com forte apoio e incentivo estatal, ancorados no aparato regulatório de que se tratou no tópico anterior.

Ao Estado coube então uma atuação decisiva, estabelecendo preços ao longo de toda a cadeia que viabilizassem as exportações, e a mobilização dos serviços da trading company da Petrobrás, Interbrás ${ }^{186}$. De acordo com estudo de O. Guerra, tais esforços foram bem-sucedidos: entre 1980 e 1981, as exportações aumentaram 300\% em peso e $250 \%$ em valor e saltam novamente após a entrada em operação do pólo de Triunfo, 188 e 174\%, respectivamente, entre 1982 e 1983. Embora a menores taxas, as exportações seguem crescendo até meados de $1985^{187}$.

Em 1987, à luz do bom desempenho exportador da indústria nacional, e da possibilidade de utilizar o gás natural descoberto na bacia de Campos/RJ como matériaprima alternativa à nafta, o governo federal lança o Programa Nacional de Petroquímica (PNP). Em linhas gerais, as propostas ali contidas eram a expansão dos pólos de Camaçari e Triunfo, desgargalamento do pólo de São Paulo e a criação de um novo pólo em Itaguaí, no Rio de Janeiro ${ }^{188}$.

Entretanto, o aparato regulatório que até então havia possibilitado a composição de interesses e a tomada de decisões estratégicas para o setor, e que fora bem sucedido na formação dos três primeiros pólos do país, desta vez não apresentaria os mesmos resultados. Naquele momento, o projeto contido no PNP foi implementado apenas parcialmente - com a ampliação de Camaçari e o início das obras em São Paulo apresentando sinais claros de que a crise econômica do país e do próprio Estado teria chegado ao ramo petroquímico brasileiro de maneira contundente.

Outros fatores também contribuíram para a deterioração do arcabouço institucional da petroquímica, como a redução significativa dos investimentos, a ampliação da distância entre os preços nacionais e os praticados no exterior (provocada pelo controle de preços no âmbito interno), e aspectos relacionados à gestão da Petroquisa e de suas subsidiárias que levariam à perda de eficiência nos gastos públicos $^{189}$. Todavia, o elemento determinante seria introduzido em 1988, momento em que se efetiva, no âmbito da política de comércio exterior, a redução das tarifas médias

\footnotetext{
${ }^{186}$ Cf. F. ERBER e R. VERMULM, Os Determinantes Estruturais...op. cit., p. 92.

${ }^{187}$ Apud F. ERBER e R. VERMULM, Os Determinantes Estruturais...op. cit., p. 92.

${ }^{188}$ F. ERBER e R. VERMULM, Os Determinantes Estruturais...op. cit., p. 96.

${ }^{189}$ Idem, p. 105 e ss.
} 
do setor petroquímico e de seus consumidores: tratava-se de um forte indício das medidas liberalizantes que estariam por vir e alterariam profundamente o ambiente da atividade petroquímica brasileira ${ }^{190}$.

Vale notar que a progressiva desarticulação dos mecanismos públicos de regulação que davam sustentação à petroquímica nacional insere-se num processo mais amplo de crescente endividamento e perda de capacidade de financiamento por parte do Estado brasileiro, e que conduziriam à desagregação de suas funções ao término dos $\operatorname{anos} 1980$.

\section{$4^{a}$ Etapa: Os anos 90 e a mudança no papel do Estado}

Os anos 1990 marcam uma importante mudança de orientação política em relação à natureza e extensão da atuação do Estado no domínio econômico que teve lugar não só no Brasil, mas em diversos países do globo. Sob o argumento da ineficiência inerente à ação pública, ao Estado se atribuiu a tarefa de desobstruir as barreiras ao funcionamento dos mercados e assegurar as condições necessárias a sua plena fluidez.

$\mathrm{Na}$ petroquímica, essa política se materializou no desmantelamento do já deteriorado arcabouço regulatório específico do setor, passando a atividade a ser coordenada predominantemente pelo jogo de mercado (ou pela concorrência) e apenas indiretamente pelo Estado, ganhando destaque sua atuação por meio da disciplina antitruste. Desse modo, em linhas gerais, promove-se a abertura às importações de produtos estrangeiros, com a remoção dos tradicionais mecanismos que protegiam o mercado interno e, no que se refere às exportações, por sua vez, o movimento teve sentido inverso, havendo eliminação dos incentivos fiscais e extinção da Interbrás.

Somem-se a isso o fim do subsídio-cruzado para nafta; a desativação das fontes oficiais de crédito subsidiado; a extinção do controle de preços, dos mecanismos de controle de investimentos e dos subsídios às exportações; além da eliminação do CDI, marcando a desintegração dos mecanismos vigentes de seleção de projetos e articulação de políticas entre os vários órgãos que influenciavam o setor, sem, no entanto, terem sido substituídos por outros órgãos e mecanismos com atribuições equivalentes.

\footnotetext{
${ }^{190}$ Idem.
} 
Finalmente, merece destaque a privatização das participações acionárias da Petroquisa contribuindo para modificar definitivamente o quadro da atividade industrial petroquímica no país. Tal medida insere-se no conjunto de políticas governamentais que integraram o Programa Nacional de Desestatização instituído pela Lei 8.031/90, em que seriam anunciados, entre outros, os seguintes objetivos fundamentais:

Art. $1^{\circ}$, inc. I - "Reordenar a posição estratégica do Estado na economia, transferindo à iniciativa privada atividades indevidamente exploradas pelo setor público;

II - Contribuir para a redução da dívida pública, concorrendo para o saneamento das finanças do setor público;

III - Permitir a retomada de investimentos nas empresas e atividades que vierem ser transferidas à iniciativa privada;

IV - Além de contribuir para modernização do parque industrial do País, ampliando sua competitividade e reforçando a capacidade empresarial nos diversos setores da economia (...)".

Em agosto de 1990, por meio do Decreto $\mathrm{n}^{\circ}$ 99.464, o governo incluiu as participações da Petroquisa no grupo prioritário do Programa de Desestatização, nomeando o BNDES órgão gestor desse processo. A partir desse momento, verifica-se uma cisão no antigo bloco de formulação e execução da política na petroquímica principalmente Petroquisa e BNDES - a respeito da forma como deveria ser conduzida a privatização no setor.

A oposição não se dava exclusivamente em razão do interesse da Petrobrás em prosseguir atuando na petroquímica, seguindo a lógica da competição internacional de que a cadeia petroquímica conta com forte participação de grandes empresas petrolíferas que ampliaram suas atividades. Um outro aspecto fundamental, relatam Erber e Oliveira, envolve o fato de que:

a manutenção do monopólio da nafta criava para a Petrobrás uma situação de ambigüidade estrutural: de um lado, era, como monopolista e aparato de Estado, responsável pelo abastecimento de uma matéria-prima indispensável para uma cadeia produtiva estratégica para o país; de outro, como empresa mista, tinha responsabilidades com seus acionistas. A compatibilização davase pela participação da Petrobrás na cadeia petroquímica: o que deixava de ganhar na venda da nafta era compensado pelos dividendos auferidos a jusante da refinaria. Com a privatização, rompia-se este mecanismo de arbitragem ${ }^{191}$.

${ }^{191}$ Cf. A Indústria Petroquímica...op. cit., p. 21 e ss. 
A despeito da oposição da Petrobrás, o processo de privatização na petroquímica teve início contando com três propostas alternativas para sua orientação, provenientes dos três principais grupos interessados:

1) Proposta defendida pela Petrobrás - privatização da Petroquisa em bloco;

2) Proposta da ABIQUIM (setor privado) - alienação da participação da Petroquisa segundo os pólos e venda conjunta da sua participação na central e nas empresas a jusante, por pólo; e

3) Proposta do BNDES - vendas independentes das participações da Petroquisa nas centrais e nas empresas de segunda geração.

Tomando em conta os objetivos explicitados pelo governo federal no sentido de formar grandes grupos nacionais capazes de competir internacionalmente, as propostas acima elencadas deveriam ser consideradas em ordem decrescente de prioridade $^{192}$. Contudo, por razões políticas - tais como a rapidez que se desejava imprimir ao processo, as dificuldades impostas pelo grande número de acionistas, pelas cláusulas restritivas dos acordos de acionistas e pela presença de vários sócios estrangeiros que competiam no exterior - a Comissão Diretora do PND, sob comando do BNDES, decidiu pela adoção da última alternativa, implementando-a, porém, por pólos. Definiuse também iniciar o processo em Triunfo, em virtude da sua menor complexidade empresarial $^{193}$.

Assim, após uma primeira tentativa de formar uma holding que reunisse os atores da segunda geração - e daria origem a uma empresa de porte internacional - por rejeição daquelas firmas ${ }^{194}$ procedeu-se ao parcelamento das vendas ao início de 1992. Como resultado, a central acabou sendo adquirida pelas empresas de segunda geração, mantendo-se uma participação minoritária de $15 \%$ por parte da Petroquisa. Na segunda geração, por sua vez, as participações da Petroquisa foram integralmente assumidas pelos sócios privados ${ }^{195}$.

No final de 1992, o clima de instabilidade e incerteza nos campos político e econômico, provocado pela exoneração do Presidente da República e de sua equipe

\footnotetext{
192 Idem.

${ }^{193}$ Idem, p. 23.

194 Idem, Ibidem. O argumento que sustentava o posicionamento das empresas de segunda geração contrário à formação da holding era de que embora tivessem interesse em participar da central para assegurar o abastecimento de matérias-primas, a sua reunião em uma única holding as levaria a participar de outras firmas nas quais não tinham interesse.

${ }^{195}$ A exceção, nesse caso, é a empresa Petroquímica Triunfo, produtora de polietileno que não participou da compra da central e posteriormente contestou judicialmente a compra das participações da Petroquisa.
} 
econômica, levou à interrupção do processo de privatização, abrindo novo espaço para os questionamentos acerca da forma como vinha sendo conduzido. Surgem então algumas propostas alternativas, com destaque para a idéia de aumentar as participações da Petrobrás nas centrais de $15 \%$ para $30 \%$, além de constituir um forte grupo privado nacional a partir da aglutinação dos interesses petroquímicos dos grupos Ipiranga, Suzano e Unipar.

Entretanto, nenhuma destas propostas foi levada adiante, de maneira que em 1993 retoma-se o processo de privatização - desta vez envolvendo os pólos de São Paulo e Camaçari - nos mesmos moldes implementados em Triunfo. Repetiu-se, portanto, a compra das participações da Petroquisa nas centrais pelas empresas de segunda geração, resguardando-se uma participação estatal minoritária de 17,5\% na PQU e $15 \%$ na Copene com vistas a garantir o abastecimento de nafta. Assim como em Triunfo, a totalidade das participações acionárias da Petroquisa nas demais firmas foi também comprada pelos parceiros privados.

Concluídas as privatizações na petroquímica brasileira, nota-se que consistiram em um processo que promoveu fundamentalmente a simplificação e concentração do intrincado arranjo acionário do setor, através da eliminação total ou parcial do controle das empresas antes exercido pela Petroquisa. Sem que tenham ocorrido fusões, incorporações e cisões de empresas, e tendo havido pouca participação das multinacionais, a estrutura produtiva na petroquímica permaneceu inalterada, mantendo as mesmas características antes e após a privatização.

Particularmente, a indústria conservou a caracterização marcada por empresas de pequeno porte empresarial, monoprodutoras e fragmentadas. Além disso, a estrutura concentrada deu lugar a um grande número de novos grupamentos acionários, originando a formação de megaholdings abrangendo diferentes acionistas - nem todos originários do setor petroquímico - sobretudo nas centrais de matérias-primas ${ }^{196}$.

A tabela a seguir apresenta as participações no faturamento bruto da petroquímica brasileira pós-privatizações ${ }^{197}$ :

\footnotetext{
${ }^{196}$ Cf. S. CÁRIO, A Relação Público-Privado...op. cit.,pp. 185-189.

${ }^{197}$ Fonte: G. R. SCHUTTE, Elo Perdido...op. cit., p. 129, elaborada a partir de estudo do BNDES.
} 


\begin{tabular}{|l|r|}
\hline Odebrecht & $47 \%$ \\
\hline Conepar - Grupo Econômico & $14 \%$ \\
\hline Ultra & $12 \%$ \\
\hline Suzano & $12 \%$ \\
\hline Unipar & $6 \%$ \\
\hline Mariani & $4 \%$ \\
\hline Ipiranga & $4 \%$ \\
\hline Peixoto de Castro & $4 \%$ \\
\hline
\end{tabular}

As transformações no arcabouço jurídico-institucional da petroquímica na década de 1990 abordadas nesta seção - a desarticulação do regime regulatório anterior e adoção de medidas como a abertura, liberalização, desregulamentação e privatizações - sucederam, conforme mencionado anteriormente, em um contexto de crise econômica interna e de baixa dos preços internacionais dos produtos petroquímicos.

A convergência desses fatores acabou trazendo à tona as deficiências estruturais da indústria nacional (e não solucionadas pelo processo de privatização) colocando-a em desvantagem na competição com as grandes empresas internacionais. Tal fator potencializou os efeitos da crise que já se caracterizava no setor desde o final da década de 1980. Entre 1991 e 2001, o déficit da balança comercial setorial (a diferença entre o valor total obtido com as importações e as exportações) aumentou progressivamente de 1,6 bilhões de dólares para 7,3 ${ }^{198}$.

A crise econômica, por sua vez, acabou se desdobrando na crise do novo aparato regulatório, que introduziu mudanças nos parâmetros de decisão estratégica das empresas e grupos do setor. Em face à ênfase excessiva na promoção de estímulos à competição (por meio da abertura e desregulamentação), em detrimento do uso de mecanismos para promover a competitividade das firmas brasileiras ${ }^{199}$, planejar e completar o processo de industrialização na petroquímica (desativados e não substituídos) - desequilíbrio este agravado pela política macroeconômica e pela baixa dos preços internacionais - o novo arcabouço institucional desencadeou, num primeiro momento, uma reação defensiva de parte dos atores econômicos ${ }^{200}$.

\footnotetext{
${ }^{198}$ G. Cf. R. SCHUTTE, Elo Perdido...ob. cit., p. 138.

${ }^{199}$ Cf. F. ERBER e R. VERMULM, Os Determinantes Estruturais...op. cit., p. 158.

${ }^{200}$ Para um balanço sobre os mecanismos de atuação do Estado brasileiro no domínio econômico, apontando para a prevalência dos instrumentos de conservação dos mercados (a disciplina concorrência) sobre aqueles destinados a sua promoção (a política industrial) e seus efeitos sobre o ambiente de inovação tecnológica, a partir das reformas dos anos 1990, ver M. G. SCHAPIRO, Política Industrial e
} 
Em um primeiro momento, as empresas responderam com a paralisação nos seus projetos de expansão e diversificação, a diminuição de custos fixos e aumento das exportações, medidas que F. Erber e R. Vermulm denominaram de ajuste estrutural defensivo $^{201}$. A partir de então, lentamente, passou a ocorrer um movimento de reposicionamento estratégico por parte dos atores na petroquímica, mediante sucessivas operações de fusões, aquisições e associações que, em atendendo aos critérios de faturamento ou participação de mercado relevante superior ou igual a $20 \%$ de que trata o art. 54 da lei 8.884/94, foram submetidas ao crivo do Sistema Brasileiro de Defesa da Concorrência, para que este pudesse atuar na prevenção ou sancionamento de possíveis danos à concorrência. Qual a resposta dada pelas autoridades antitruste nesses casos?

\section{Considerações finais}

Neste capítulo foram abordadas as características gerais da indústria petroquímica e foi possível observar o seu distanciamento em relação ao modelo de mercado perfeitamente competitivo. Em razão de seus determinantes técnicoeconômicos, a petroquímica exige uma forma peculiar de coordenação econômica.

Observou-se que, no mundo todo, o padrão de organização do setor consiste na presença de estruturas integradas vertical e horizontalmente para reduzir custos de transação, o que por sua vez constitui condição inafastável para a competitividade internacional. A indústria petroquímica brasileira, por sua vez, apresenta como característica específica a falta de integração, a especialização em produtos de baixo valor agregado e setor privado com baixa capacidade de promover investimentos.

Historicamente, houve participação estatal nessa atividade, não apenas de forma direta - por meio da Petroquisa na qualidade de proprietária de alguns empreendimentos - mas também estabelecendo um complexo sistema de normas e instituições voltadas à proteção e estímulo do setor. Na classificação de F. Erber e R. Vermulm, o arcabouço regulatório contava com cinco tipos de mecanismos: a) redutores de incerteza do investimento; b) redutores de custo de investimento; c) redutores de custo de operação; d) apoio à exportação; e e) pressões para realização de atividade tecnológica no país.

Disciplina da Concorrência Pós-Reformas de Mercado: Uma Avaliação do Ambiente de Inovação Tecnológica (Dissertação de Mestrado), São Paulo, FD-USP, 2005.

${ }^{201}$ Os Determinantes Estruturais...op. cit., p. 138 e ss. 
Durante os anos 1990, no contexto das reformas de mercado e do Estado, verificou-se a diminuição e mudança qualitativa na esfera de ação pública na economia como um todo, com reflexos no setor. De proprietário dos empreendimentos petroquímicos e indutor do desenvolvimento, o Estado passou a se concentrar na atividade de regulação dos mercados por meio de mecanismos de caráter menos interventivo, e mais "corretivo" de eventuais abusos e por isso mesmo horizontais, isto é, sem estabelecer distinções entre os setores da economia.

A proposição nesse momento era de que a coordenação da atividade petroquímica ficaria a cargo do sistema de mercado e da concorrência, que passaria a envolver uma dimensão internacional, dada a abertura da economia brasileira. Nesse novo arranjo, ao Poder Público incumbe a tarefa de assegurar as condições de competição. A promulgação da Lei 8.884/94 e o fortalecimento institucional do Conselho Administrativo de Defesa Econômica (CADE) marcam essa nova etapa e, como visto no capítulo 2, tampouco estabelece qualquer tipo de isenção ou diferenciação em relação aos ramos de atividade da economia.

Dadas essas características da legislação brasileira de defesa da concorrência, o próximo capítulo procura registrar o movimento recente de reestruturação da petroquímica desencadeado pelas mudanças introduzidas no ambiente jurídicoinstitucional e examinar a orientação da disciplina antitruste nesse quadro. Pretende-se, assim, analisar se a aplicação do direito concorrencial foi suficientemente aberta e flexível para possibilitar o processo de concentração necessário à consolidação desse setor e o aumento de sua competitividade internacional. 


\section{CAPÍTULO 4 - O DIREITO DA CONCORRÊNCIA APLICADO AO SETOR PETROQUÍMICO BRASILEIRO}

O setor petroquímico corresponde ao ramo da atividade econômica em que o movimento de concentração de empresas no Brasil foi mais intenso na última década ${ }^{202}$, o que ocasionou a submissão de um grande número de casos ao CADE. Esse fato é reflexo do processo de reorganização da indústria impulsionado com as mudanças no ambiente jurídico-institucional realizadas durante os anos 1990.

Alguns desses casos representam apenas descruzamentos de participações acionárias, sem alteração do controle das empresas, e são analisados pelas autoridades de defesa da concorrência seguindo um rito sumário, por considerarem que não acarretam problemas concorrenciais. Em diversos casos, por sua vez, há mudança de controle nas empresas envolvidas, exigindo apreciação mais criteriosa sobre os efeitos da operação.

A título de exemplo podem ser mencionados os complexos processos referentes à reestruturação das centrais petroquímicas: o Ato de Concentração $\mathrm{n}^{\circ}$ 08012.005799/01-92 julgado em 2005, que trata do Pólo de Camaçari e tem como requerentes a COPENE, Odebrecht - Braskem e o grupo Mariani; e os atos de concentração ainda sob exame do SBDC que envolvem a reestruturação do Pólo de Triunfo (Ato de Concentração n ${ }^{\circ}$ 08012.002818/07-14, Requerentes: Petrobrás, Ultrapar, Braskem e Ipiranga) e do Pólo do Sudeste (entre outros, há o Ato de Concentração nº 08012.011068/2007-71, Requerentes: Petrobras e Suzano Petroquimica S/A).

Este capítulo apresenta os principais desdobramentos recentes na organização da indústria petroquímica no Brasil e, nesse contexto, trata de alguns dos casos que têm sido avaliados pelas autoridades de defesa da concorrência. O objetivo é analisar se a aplicação do direito concorrencial foi suficientemente aberta e flexível para permitir o processo de concentração necessário à consolidação desse setor ou se, pelo contrário, implicou algum tipo de obstáculo ao aumento da competitividade internacional das empresas atuantes nesse ramo.

202 “Concentração industrial aumenta no País: Movimento foi mais forte nas áreas de petroquímica e química, revela trabalho de ex-Conselheira do Cade", in O Estado de São Paulo, 16/07/2007, p. b5. 


\section{Nota metodológica}

Esta etapa da pesquisa baseou-se nos pareceres e decisões disponíveis na base de dados dos órgãos que integram o Sistema Brasileiro de Defesa da Concorrência (CADE, SDE e SEAE) $)^{203}$ e em notícias veiculadas pela mídia, sobretudo em relação às operações que foram apresentadas recentemente e ainda não foram julgadas (em particular os jornais Folha de São Paulo, O Estado de São Paulo e Valor Econômico).

Desde 1995, por volta de 300 atos de concentração econômica envolvendo empresas com atividades nas áreas química e petroquímica foram notificados ao CADE. A dificuldade prática de reunir informações junto à base de dados do CADE na internet - uma vez que a pesquisa pode ser feita por ano, número de processo ou nome das partes, mas não por setor de atividade econômica ou mercado de produtos envolvido na operação - e também a complexidade de produtos e subprodutos envolvidos na petroquímica impuseram a necessidade de delimitar um recorte para seleção dos casos a serem abordados nesta seção.

Diante disso, após um primeiro levantamento de caráter mais geral, foi possível observar que uma parcela significativa dessas decisões refere-se a operações cujas partes integram o grupo da chamada terceira geração da cadeia petroquímica. Por se tratar justamente de um elo da produção onde a estrutura de mercado se caracteriza por ser mais pulverizada (ou mais concorrencial) e, portanto, teoricamente menos suscetível de questionamentos em matéria antitruste, optou-se aqui por excluí-los do campo de estudo.

Assim, foram tomados casos cujo mercado relevante envolvesse produtos integrantes da primeira e/ou segunda geração da petroquímica e, dentre esses, aqueles que mais especificamente se referissem aos produtos eteno e propeno (primeira geração), polietileno e polipropileno (segunda geração). Nesse universo, foram selecionados os casos representativos das principais direções em que avançou o processo de reestruturação do setor, e cuja solução pelas autoridades antitruste evidencia de forma mais imediata a problemática de incorporar parâmetros para aplicação da lei

\footnotetext{
${ }^{203}$ http://www.cade.gov.br, http://www.mj.gov.br/sde, http://www.seae.fazenda.gov.br.
} 
que sejam suficientemente flexíveis para possibilitar o aumento de competitividade na petroquímica.

Esse recorte encontra justificativa no fato dos primeiros dois segmentos da cadeia de produção corresponderem aos mais concentrados sendo, por conseguinte, mais acentuado o potencial de prejuízo à concorrência. Por conta disso, a discussão sobre as possíveis justificativas para as operações ou a imposição de eventuais condições para aprovação também se torna mais sensível, o que permite refletir sobre os objetivos da aplicação do direito concorrencial, as suas bases conceituais e seus impactos sobre esse setor específico da economia. No que se refere à escolha dos produtos, tratam-se dos mais importantes desse setor e correspondentes a maior parte do volume de produção.

Feitas essas observações, nota-se que resultou da seleção uma amostra composta pelos seguintes casos:

\section{JÁ JULGADOS:}

1) $\mathrm{AC} \mathrm{n} \mathrm{n}^{\circ} 54 / 95$

Requerentes: COPESUL, OPP Petroquímica, OPP Polietilenos e Ipiranga

2) $\mathrm{AC} \mathrm{n}^{\circ} 189 / 97$

Requerentes: OPP e Petrobrás (Pólo Paulínia)

3) $\mathrm{AC} \mathrm{n}^{\circ} 08012.007759 / 1999-91$

Requerentes: Union Carbide e Dow Chemical

4) $\mathrm{AC} \mathrm{n}^{\circ} 08012.004012 / 1999-07$

Requerentes: OPP Petroquímica S/A e Borealis S/A

5) $\mathrm{AC} \mathrm{n}^{\circ} 08012.006452 / 00-86$

Requerentes: Suzano, UNIPAR, Petroquisa, BNDES (Pólo RJ)

6) $\mathrm{AC} \mathrm{n}^{\circ} 08012.006110 / 2000-66$

Requerentes: Borealis S/A e OPP Petroquímica S/A, empresa do grupo Odebrecht

7) $\mathrm{AC} \mathrm{n}^{\circ} 08012.005799 / 01-92$

Requerentes: COPENE, Odebrecht (Braskem - Pólo Camaçari)

8) $\mathrm{AC} \mathrm{n}^{\circ} 08012.005811 / 2003-21$

Requerentes: Braskem e Mitsubishi Chemical

9) $\mathrm{AC} \mathrm{n}^{\circ}$ 08012.004506/04-01

Requerentes: Dow e Petroquisa (Petroquímica Triunfo)

10) $\mathrm{AC} \mathrm{n}^{\circ} 08012.005598 / 05-19$

Requerentes: Braskem e Petroquisa

11) $\mathrm{AC} \mathrm{n}^{\circ} 08012.002974 / 2006-02$

Requerentes: Braskem, Itochu Corporation, SPQ Investimentos e partic. Ltda e Sumitomo Chemical Company 


\section{AINDA NÃO JULGADOS:}

1) $\mathrm{AC} \mathrm{n} \mathrm{n}^{\circ} 08012.002813 / 2007-91$ Requerentes: Braskem S/A e Petróleo Brasileiro S/A - Petrobrás

2) $\mathrm{AC} \mathrm{n}^{\circ} 08012.002818 / 2007-14$

Requerentes: Petróleo Brasileiro S/A - Petrobrás Ultrapar Participacoes S/A Braskem S/A e Refinaria de Petróleo Ipiranga S/A

3) $\mathrm{AC} \mathrm{n}^{\circ}$ 08012.002820/2007-93

Requerentes: Petróleo Brasileiro S/A - Petrobrás e Refinaria de Petróleo Ipiranga $\mathrm{S} / \mathrm{A}$

4) $\mathrm{AC} \mathrm{n}{ }^{\circ} 08012.009856 / 2007-06$

Requerentes: Unipar - União de Indústrias Petroquímicas S/A e Dow Brasil S/A

5) $\mathrm{AC} \mathrm{n}{ }^{\circ} 08012.011068 / 2007-71$

Requerentes: Petróleo Brasileiro S/A - Petrobrás e Suzano Petroquimica S/A

6) Constituição do Pólo Petroquímico do Sudeste

Operação envolvendo ativos da Unipar e Petrobrás

É importante mencionar que embora não seja possível fazer uma discussão mais aprofundada sobre estas operações recentes envolvendo atores importantes da petroquímica nacional, tendo em vista que esses processos encontram-se atualmente sob exame das autoridades do Sistema Brasileiro de Defesa da Concorrência, sem que tenha ocorrido publicação dos pareceres dos órgãos instrutores, esses casos serão aqui tratados de forma sucinta, apenas a título de registro da tendência que vem assumindo a reorganização do setor e dos desafios a serem enfrentados do ponto de vista da disciplina da concorrência.

\section{Breve panorama sobre a reestruturação recente na indústria petroquímica brasileira}

Em linhas gerais, o movimento de reorganização ou consolidação da indústria petroquímica nacional tem se voltado à substituição daquela configuração tradicionalmente fragmentada por estruturas empresariais mais concentradas e integradas, sobretudo nos dois primeiros segmentos da cadeia de produção. Isso se deve ao diagnóstico de que o modelo anterior não permitia a internacionalização, restringia ganhos de escala e limitava a capacidade de investimento e expansão.

Tais elementos, somados à ameaça iminente representada pelas grandes empresas multinacionais com atuação global, levaram a que a concentração na 
petroquímica nacional passasse a ser vista como algo inevitável. Observa-se, assim, que houve uma mudança em relação à visão que saiu vencedora na privatização, cujo resultado mostrou-se inadequado para solucionar os problemas desse setor, já que tardou mais de quinze anos até que pudesse assumir um arranjo mais integrado e competitivo ${ }^{204}$.

A primeira etapa desse processo consistiria no redesenho do setor petroquímico em torno de duas grandes empresas nacionais, a Braskem, pertencente ao grupo Odebrecht, e a Unipar. A operação que marca o início dessa estratégia refere-se à reestruturação do Pólo Petroquímico de Camaçari, na Bahia, realizada em 2002, pela qual a Braskem assumiu o controle da empresa associando-se ao grupo Mariani. O passo seguinte foi dado somente no mês de março de 2007, com o anúncio da compra da Ipiranga por um consórcio formado entre a Petrobrás, a Braskem e o grupo Ultra. Dessa operação resultou um novo arranjo também para o Pólo de Triunfo, no Rio Grande do Sul, com o fortalecimento da presença da Braskem na região e a revitalização da participação estatal no setor.

A consolidação da Braskem nas regiões nordeste e sul acabou acelerando o processo de concentração no sudeste, onde subsistiam dois grupos principais, Suzano e Unipar. Neste caso, o impulso inicial foi dado pela operação de compra da Suzano por parte da Petrobrás, em agosto de 2007, e posterior associação entre a Petrobrás e a Unipar para formação de uma nova empresa, provisoriamente denominada de Companhia Petroquímica do Sudeste ${ }^{205}$. Os acordos realizados no início de dezembro de 2007 entre Petrobrás e Braskem, por um lado, e Petrobrás e Unipar, por outro lado, de que resulta a consolidação da presença estatal nas duas empresas privadas, encerraram essa primeira etapa ${ }^{206}$.

A segunda etapa do processo de reestruturação da petroquímica brasileira envolve a construção do Complexo Petroquímico do Rio de Janeiro - Comperj concebido pela Petrobrás para enfrentar um dos principais obstáculos à expansão da produção petroquímica nacional, que é a carência de matérias-primas. Atualmente, a Petrobrás tem capacidade para fornecer cerca de $70 \%$ da nafta utilizada por essa indústria, sendo importados os $30 \%$ restantes. O projeto prevê que a Comperj utilize como matéria-prima o petróleo pesado extraído de Campos, no Rio de Janeiro, o que

\footnotetext{
204 "Investimento em petroquímica deve crescer 220\%, diz BNDES”, in Folha de São Paulo, 16/08/2007, - caderno Dinheiro.

205 "Petrobrás e Unipar analisam integração do BNDES na CPS", in Valor Econômico, 19/09/2007.

206 "Unipar e Petrobrás criam nova empresa", in Folha de São Paulo, 01/12/2007, caderno Dinheiro.
} 
exigiria o emprego de uma tecnologia nova para a fabricação de produtos petroquímicos. Por essa razão, o volume de investimentos estimados para o empreendimento é por volta de R\$ 17 bilhões até 2012, ano esperado para sua entrada em operação ${ }^{207}$.

Tendo descrito de forma sucinta as principais direções a que têm apontado a reorganização da petroquímica brasileira, na seqüência passa-se à apresentação dos casos selecionados e que foram levados ao Sistema Brasileiro de Defesa da Concorrência naquele percurso. O objetivo é analisar como as autoridades antitruste interpretaram o setor e quais as justificativas aceitas para o significativo aumento da concentração de mercado. Em última instância, pretende-se reunir alguns elementos para refletir sobre o funcionamento da disciplina da concorrência no Brasil e sua relação com as necessidades de estruturação de um ramo específico da indústria, necessidade típica de países em desenvolvimento.

\section{A petroquímica no CADE}

Um dos primeiros casos de concentração econômica na petroquímica a ser tratado pelo CADE, desde a promulgação da Lei $n .{ }^{\circ}$ 8.884/94, foi o polêmico processo envolvendo o contrato de fornecimento de matérias-primas entre a central Copesul Companhia Petroquímica do Sul - e as empresas OPP Petroquímica S/A, Poliolefinas S/A e Polisul Petroquimica S/A, atuantes na segunda geração (AC n. ${ }^{\circ}$ 54/95). O objeto da negociação era um pedido, por parte destas empresas, de que a Copesul expandisse a produção de eteno e propeno, indispensáveis à fabricação dos produtos de segunda geração. A previsão de duração do acordo era de quinze anos, renováveis por mais cinco.

O contrato em questão, com efeito, enquadrava-se nos critérios fixados pelo art. 54 da legislação concorrencial que determina a obrigatoriedade de submissão ao CADE de atos de concentração. Naquela ocasião, contudo, instaurou-se a polêmica fundamentalmente em virtude do ingresso ao processo na qualidade de "parte interessada", da Petroquímica Triunfo S/A, empresa também atuante na segunda geração que não firmara o referido acordo para fornecimento de matéria-prima, e que argumentava ter havido recusa ou tratamento desigual pela Copesul. Conforme registro

\footnotetext{
207 "Investimento em petroquímica deve crescer 220\%, diz BNDES", in Folha de São Paulo, 16/08/2007, Caderno Dinheiro.
} 
do Conselheiro-Relator do caso, Antonio Fonseca, a Triunfo atribuía à Copesul uma prática anticompetitiva de abuso de posição dominante, em virtude da existência de relação de dependência econômica das empresas de segunda geração e a Central de matérias-primas.

O caso é interessante não apenas por ter suscitado debate sobre as relações de concorrência na petroquímica, mas também por revelar ter ocorrido um deslocamento dos conflitos e das disputas de interesses intrínsecos ao setor para o âmbito do antitruste, representado nos órgãos do Sistema Brasileiro de Defesa da Concorrência. Nesse sentido, é bastante expressivo o minucioso relato do Conselheiro Antonio Fonseca a respeito das sucessivas manifestações das partes, tanto as requerentes do ato de concentração, como também da "interessada" Triunfo. Além disso, o prolongado período de instrução do processo e a controvérsia instaurada, cujo julgamento veio a ocorrer em 1997, exprimem também um debate sobre a natureza e a extensão do papel do CADE e uma interessante reflexão sobre os limites de sua atuação.

Outro aspecto que salta aos olhos nesse caso é a pluralidade de opiniões expressa nos pareceres dos órgãos integrantes do sistema antitruste. A esse respeito, mencionemse, por exemplo, as seguintes manifestações:

(a) SEAE - Dentro de um ponto de vista estritamente econômico, considerou que "os acordos não são passíveis de aprovação, por seus efeitos perniciosos ao mercado de polietileno, não sendo compensatórios os ganhos de eficiências indicados”;

(b) Coordenadora Geral do DPDE/SDE - Reconhece inviabilidade de fornecimento de eteno à Petroquímica Triunfo S/A por outra via senão o terminal COPESUL e que, com a expansão, as empresas Poliolefinas, Petroquímica Triunfo e Polisul passarão a ser concorrentes entre si, razão pela qual entendeu haver o CADE que adotar uma medida preventiva, com vistas a evitar prejuízos futuros à competição entre aquelas empresas. Em relação ao mercado geográfico, definiu-o como abrangendo as regiões Sul e Sudeste do País;

(c) Secretário da SDE - Entendeu necessária a expansão, “(...) tendo em vista a melhoria da produtividade e eficiência das empresas" que fazem parte no pacto, sendo atendido o disposto noß $1^{\circ}$ do mesmo art. 54 e, assim, não cabendo ao CADE a adoção de qualquer medida estrutural; e

(d) Procuradoria do CADE - Concluiu pela aprovação dos acordos de fornecimento de eteno e propeno, argumentando revelarem uma eficiente cooperação econômica entre os Grupos Odebrecht e Ipiranga constituída a partir do processo de 
privatização da COPESUL. Considerou não existir concorrência entre as empresas que o integram no que se refere ao mercado relevante de eteno em Triunfo - RS. Concluindo, finalmente, que os contratos decorrem de processo natural fundado na maior eficiência do agente econômico em relação aos seus competidores, em sintonia com o objetivo do Programa Nacional de Desestatização e que, nesses termos, resultaria em exercício regular do poder econômico, o qual não encontra restrições no ordenamento jurídico brasileiro.

Também entre os Conselheiros do CADE revelou-se haver visões distintas sobre o caso sob exame. Nesse sentido, veja-se a síntese dos votos:

(a) Conselheiro Relator Antonio Fonseca - Conforme seu entendimento,

(...) embora a expansão do Pólo Petroquímico do Sul seja geradora de benefícios, a forma como está sendo apropriada a produção futura de matérias-primas retira competitividade de uma das empresas (Triunfo) em favor de outras duas (OPP Polietilenos e Ipiranga), além de indicar uma tendência de domínio futuro de mercado por parte das empresas produtoras de polietileno que têm participação acionária na central.

Votou, então, pela aprovação dos contratos submetida a condições de duas ordens: preventivas, com o objetivo de prevenir que distorções futuras decorrentes da política de suprimento de matérias-primas no Pólo pudessem resultar em ofensa à ordem econômica; e reparadoras, a fim de "eliminar os efeitos imediatos adversos à ordem econômica e, em particular, à interessada Triunfo";

(b) Conselheiro Renault de Freitas Castro - Concordou com voto do relator de que houve prova da exclusão de concorrente, e que a origem desse fato remonta à falha do processo de privatização, por não ter determinado regras claras sobre o relacionamento entre as firmas concorrentes. Votou, então, pela aprovação do ato sujeita às restrições de mesma natureza propostas pelo Relator;

(c) Conselheiro Arthur Barrionuevo - Votou pela aprovação sem restrições, entendendo que os indícios de infração à concorrência (a exclusão da Triunfo por parte da Copesul na negociação da expansão do fornecimento de matérias primas) não terem se convertido em prova;

(d) Conselheiro Paulo Dyrceu Pinheiro - Considera que 
as limitações criadas pelos acordos de fornecimento e as dimensões do projeto de ampliação da Copesul não têm por motivo a preservação de uma posição monopolística nos mercados relevantes de resinas mediante a exclusão de um concorrente.

Admite, entretanto, os riscos de prejuízos futuros em relação aos concorrentes da segunda geração que não ingressaram no acordo, razão pela qual concorda com a necessidade de adoção de alguma medida preventiva. Manifesta, entretanto, a preocupação com o tipo de intervenção que caberia ao CADE, à luz da sugestão do Relator de se implementar medida reparadora:

(...) não seria salutar (...) a imposição de medidas corretivas de duvidosa eficácia e conducentes a possíveis ineficiências, quase sempre fatal em mercados tão competitivos, com base no questionamento da 'lógica que envolveu a escolha da capacidade produtiva de eteno', e em estimativas de excedentes de matérias primas calcadas em níveis hipotéticos de consumo, por cuja margem de erro o CADE não poderia assumir qualquer responsabilidade;

(e) Presidente Gesner de Oliveira - Considerou não haver prova da recusa por parte da Central, e que o impacto dos acordos no mercado, no curto prazo, eram negligenciáveis, não subsistindo suporte fático nem legal para a intervenção do CADE. Entendeu, contudo, que no médio ou longo prazo, as empresas com plantas antigas, sem acesso a adicionais de eteno, tenderiam a ficar obsoletas frente ao avanço tecnológico representado pelas plantas "swing" PEBDL-PEAD. Tal perspectiva de redução futura da concorrência justificaria a atuação preventiva do CADE. Entretanto, nos termos dos itens "a", "b" e "c" do inciso I do parágrafo $1^{\circ}$ do artigo 54 da lei 8884/94, considerou inegável que a integração representada pelos acordos em exame resultaria em aumento de produtividade, melhoria da qualidade do produto final, promoção de eficiência e desenvolvimento tecnológico, que seriam equitativamente distribuídos entre participantes e usuários finais. Desse modo, de fato não haveria eliminação de parte substancial da concorrência, como prevê o inciso III do art. 54, “mas apenas uma perspectiva de redução gradual de participação de concorrentes desatualizados tecnologicamente”. Votou, então, pela aprovação da operação condicionada à oferta pública antecipada de excedentes ao plano de expansão, visando garantir às empresas 
concorrentes que tencionassem desenvolver plantas atualizadas tecnologiamente o acesso aos novos estoques de matéria prima provenientes da Copesul;

(f) Conselheira Lucia Helena Salgado - Manifestou em seu voto que, ao perquirir se houve de fato exclusão de concorrente no caso em tela, seria necessária a comprovação de que a conduta refletiria uma estratégia com o claro propósito de eliminação de concorrente, o que não lhe pareceu ter havido. Por outro lado, identificou a não inclusão da Triunfo no acordo como uma falha de coordenação originada por um conjunto de fatores e que a perpetuação dessa falha poderia levar ao efeito de inviabilizar a sobrevivência de concorrente eficiente no mercado. Diante disso, a autoridade antitruste estaria obrigada a agir de forma preventiva, com vistas a restabelecer as condições de igualdade de acesso à matéria-prima, respeitada a viabilidade econômica de projetos de investimento já em andamento. Sobre o papel da defesa da concorrência, mais precisamente, avalia:

Ao constatar a falha de coordenação não cabe ao CADE sobreporse aos agentes privados alterando decisões de investimento já implementadas. (...) Tampouco é função da autoridade antitruste reparar falhas de coordenação de decisões empresariais como as que se constatou como uma atividade estranha à aplicação rigorosa da lei de defesa da concorrência. Cabe ao CADE por outro lado - no desempenho de sua função preventiva - impedir que por razões alheias à eficiência econômica e por força do uso abusivo do poder de mercado - players independentes e economicamente eficientes sejam de forma irreversível inviabilizados, reduzindo o bem-estar da sociedade.

A Conselheira vota pela aprovação da operação sob a condição de contratação de consultoria internacional para promover estudos e providências necessários para avaliar e executar três conjuntos de medidas: 1) direcionadas ao desenho de um programa de desgargalamento com vistas a atender a demanda das empresas de segunda geração não integrantes dos grupos controladores da central, para o qual deverá haver oferta pública; 2) direcionadas à realização de oferta pública de excedentes decorrentes da diferença entre as quantidades contratadas e a capacidade de consumo de cada planta; e 3) direcionadas a incluir todos os competidores atuantes no mercado relevante e evitar que sejam excluídos de futuros projetos de expansão;

(g) Conselheiro Leônidas Xausa - Por fim, este voto foi pela aprovação do acordo com restrições, tais como propostas pela Conselheira Lucia Helena Salgado. 
Argumentou, entretanto, que não seria possível falar em recusa de fornecimento por parte da Copesul, por entender que

todas as vantagens relativas, alegadas em favor da Copesul, as discriminações, as restrições colaterais e desvantagens não decorrem de um ato de vontade de quem quer que seja a não ser da própria Petroquímica Triunfo, (...) por livre escolha de uma estratégia que não cabe ao Plenário do CADE discutir.

Assim, a votação de um caso tão controvertido como esse levou o plenário à decisão de aprovar a operação, sujeita, entretanto, às medidas preventivas tal como propostas pela Conselheira Lucia Helena Salgado. Os mercados considerados relevantes para a análise, do ponto de vista geográfico, foram delimitados como sendo a região Sul na qual se situa a Copesul, em relação à matéria-prima eteno, e o Mercosul, para os produtos de segunda geração. Entretanto, os segmentos da cadeia foram tomados como empreendimentos separados, o que levou o CADE à adoção de medidas estruturais. Cumpre notar, ainda, que as "eficiências" do acordo não foram propriamente questionadas, mas admitidas por praticamente todos como tendência natural do setor à integração. Uma exceção a esse respeito pode ser identificada em relação ao tratamento das integrações verticais manifestado no voto do Relator, que as interpreta como barreiras à entrada de novos concorrentes e instrumento de fortalecimento da posição monopolista das centrais petroquímicas ${ }^{208}$.

Desse modo, o que o caso explicita de maneira mais notória é a relação conflituosa entre os atores econômicos da petroquímica, o que por sua vez levantou o debate entre as autoridades sobre o objeto e os objetivos da aplicação do direito da concorrência: o ingresso da Triunfo ao processo na qualidade de "parte interessada" uma figura estranha ao procedimento administrativo - acabou resultando na instauração de um verdadeiro contraditório em relação à decisão de um ato de concentração. Esse fato, acentuado pelo entendimento de dois conselheiros no sentido de ter efetivamente havido exclusão de um concorrente, razão pela qual o CADE deveria adotar medidas reparadoras, levou outros conselheiros à afirmação freqüente no âmbito do antitruste de

\footnotetext{
${ }^{208}$ O Relator chama a atenção para a necessidade de "considerar que o setor tende a responder a uma crescente integração vertical e escala. A leitura dessa tendência é uma ampliação das barreiras à entrada. Isso reforça o diagnóstico de que o estrangulamento da Triunfo certamente possibilitará movimentos de elevação de preços devido à redução do vigor concorrencial no mercado de polietileno".
} 
que este não se presta à defesa de agentes econômicos específicos, mas sim à garantia do processo competitivo como um todo.

Alguns anos depois, em 1997, o Sistema Brasileiro de Defesa da Concorrência passaria a apreciar outro processo de concentração envolvendo a petroquímica, constituindo o primeiro passo na tentativa de reestruturação do setor. Tratava-se do AC n. ${ }^{\circ}$ 189/97, pelo qual a OPP Petroquímica (“OPP”, do grupo Odebrecht) e a Petrobrás se associavam para a formação de um Pólo Petroquímico em Paulínia, o que já sinalizava a pretensão da Odebrecht em se tornar a grande empresa nacional da petroquímica. Diferentemente do caso anterior, desta vez não houve polêmica entre as autoridades do sistema antitruste a respeito da natureza da associação e dos seus efeitos.

No entanto, a operação em tela desencadeou a discussão sobre a possível retomada da presença estatal na petroquímica e, principalmente, sobre a relação quase que exclusiva que a Petrobrás travaria com a Odebrecht, provocando a reação das concorrentes Mariani, Suzano e Ipiranga. Em conseqüência, essas empresas levantaram o questionamento acerca da possibilidade de constituição de uma subsidiária da Petrobrás sem autorização legal, como também o fato desta se associar com um ente privado sem realização prévia de procedimento licitatório.

Os principais alvos de crítica eram o fato da Odebrecht possuir poder de veto, o que limitaria ainda mais a concorrência em um setor onde já havia poucas empresas atuando, além de que o contrato não colocava restrições para que esta empresa negociasse, num segundo momento, suas participações no Pólo de Paulínia com um grupo internacional. Estes argumentos foram utilizados em denúncia encaminhada pelo Senado à Secretaria de Direito Econômico (SDE) de que o contrato era lesivo à concorrência $^{209}$.

Mais tarde, também a empresa PQU veio manifestar-se publicamente em contra do $\operatorname{acordo}^{210}$ :

A associação, da forma estabelecida em contrato, cria dificuldades incontornáveis ao desenvolvimento do Pólo Petroquímico de São Paulo (Capuava), além de prejudicar a entrada de novas empresas no mercado, impedindo o livre acesso às fontes de matérias-primas e aos canais de distribuição, porque estarão subordinados somente aos interesses da associação prevista.

\footnotetext{
${ }^{209}$ Cf. G. R. SCHUTTE, Elo perdido...cit., p. 213

${ }^{210}$ Apud G. R. SCHUTTE, Elo perdido...cit., p. 214.
} 
Como aponta G. R. Schutte ${ }^{211}$, "a grande indústria petroquímica estava nascendo, mas as demais empresas se sentiram discriminadas e contestaram firmemente a opção da Petrobrás". Todavia, o movimento contrário à operação acabou se estendendo a outros setores da sociedade, ganhando status de uma verdadeira campanha nacional e trazendo à tona o debate entre posturas tradicionalmente defendidas por "desenvolvimentistas" - em favor da associação entre Petrobrás e Odebrecht e da formação da grande empresa nacional - e "liberais" - em contra do acordo e do fortalecimento de um grupo privado em detrimento dos demais atuantes no setor.

Numa tentativa de encerrar a polêmica, o então presidente da República Fernando Henrique Cardoso afirmou em entrevista querer grupos fortes em vários pólos, mas que não poderia haver concentração em torno de um só grupo, devendo a Petrobrás diversificar suas parcerias no país ${ }^{212}$.

Alguns fatores contribuiriam para o "esvaziamento" do debate sobre o projeto de constituição do Pólo de Paulínia (impedindo que saísse do papel naquele momento) e a definição de uma diretriz política para a reorganização setor. De um lado, o deslocamento da discussão para o âmbito jurídico, pertinente à regulamentação da nova lei de petróleo, uma vez que o fim do monopólio dera à Petrobrás a liberdade de atuação e deu abertura para processos de negociação de parcerias pouco transparentes (autorizadas pelo artigo 63 da lei). Isso entrava em choque com os princípios constitucionais da impessoalidade e publicidade (ou transparência) a que devem atender os órgãos da administração pública direta ou indireta ${ }^{213}$. Por outro lado, o impacto da crise asiática na economia brasileira, com aumento dos juros e queda dos preços petroquímicos, aumentaria a já fragilizada saúde financeira da Odebrecht, levando-a a suspender temporariamente seus projetos de expansão.

Em março de 2000, o CADE emitiria sua decisão sobre o caso, mas a essa altura o projeto já havia sido deixado de lado. O mercado relevante delimitado foi o dos produtos de primeira e segunda geração e, do ponto de vista geográfico, assim como no AC 54/95, a região do Planalto Paulista para os produtos básicos fornecidos para a segunda geração e, para esta última, o Mercosul. A análise da estrutura desses mercados levou à conclusão de que, embora o grupo Odebrecht detivesse participação elevada nos mercados de termoplásticos ( $2^{\mathrm{a}}$ geração), a associação com a Petrobrás não acentuaria a

\footnotetext{
${ }^{211}$ Cf. Elo perdido...op. cit., p. 211.

${ }^{212}$ G. R. SCHUTTE, Elo perdido...op. cit., p. 217.

${ }^{213}$ Idem, p. 218.
} 
concentração horizontal. Entretanto, a operação resultaria numa integração vertical, uma vez que levaria a empresa estatal monopolista na oferta de insumos petroquímicos a atuar nos segmentos petroquímicos de primeira e segunda geração e, por outro lado, associaria o grupo Odebrecht, por meio da OPP, à empresa que lhe fornece insumos.

Diante disso, passou-se à análise acerca dos possíveis efeitos dessa associação em relação às decisões de investimentos dos demais concorrentes, como também se buscou verificar se ela levaria a obstrução do acesso ao mercado para essas empresas e acarretaria uma progressiva concentração do setor sob a responsabilidade da Odebrecht. A esse respeito, o parecer da SDE, assim como a manifestação do Conselheiro-Relator do processo (Ruy Santacruz) convergiram no sentido de que o contrato firmado pelas requerentes continha cláusulas com potencial de restringir a concorrência - vez que as elevadas barreiras à entrada existentes no setor representavam potencial de exercício abusivo do poder econômico - motivo pelo qual sugeriam nova redação a três das onze cláusulas contratuais como condição para aprovação da operação. A proposta foi ratificada por unanimidade na plenária de julgamento do processo em questão.

De acordo com o Relator,

o contrato realizado entre OPP e Petrobrás diz respeito à instalação de um novo pólo petroquímico. Nesse sentido, amplia a capacidade produtiva e apresenta, por si só, efeitos positivos sobre a concorrência. Entretanto, o acordo contém cláusulas de preferências que podem limitar ou de qualquer forma prejudicar a concorrência, ao estabelecer uma integração vertical entre produtora estatal monopolista de matérias-primas e um de seus consumidores, que extrapolaria o empreendimento objeto do contrato.

Nesse ponto, vale destacar que ao propor as medidas para prevenir as potenciais restrições à competição, assim como no AC n. ${ }^{\circ}$ 54/95, o Conselheiro do CADE enfatiza os aparentes limites da atuação da autoridade antitruste nos processos econômicos:

É importante ressaltar o óbvio. O CADE não faz política industrial, embora a considere nas suas decisões, até mesmo por força do parágrafo $2^{\circ}$, artigo 54 da lei 8.884. O CADE apenas aplica a lei de defesa da concorrência, consideradas as exigências de segurança jurídica e transparência. A aplicação da norma legal exige estabilidade e clareza nas decisões, permitindo ao administrado a certeza necessária nas suas ações de mercado. A defesa da concorrência é, nesse sentido, uma ação de Estado. 
Dessa maneira, não pode o CADE (...) impedir a associação entre OPP e Petrobrás por uma questão de 'isonomia' com os outros concorrentes, que teriam 'direito' ao mesmo tratamento por parte da empresa estatal. Também não poderia permitir a associação dentro de uma perspectiva de política industrial, na qual a OPP surgiria como a empresa 'eleita' por suas 'qualificações', para se tornar o grande ator petroquímico no mercado internacional. Cabe ao CADE simplesmente decidir com base na melhor jurisprudência nacional e internacional, observados os limites legais, se o contrato sob exame é capaz de limitar ou de qualquer forma prejudicar a concorrência, na forma acima mencionada.

$\mathrm{Na}$ seqüência, todavia, o voto do Relator recupera rapidamente o percurso histórico de atuação do Estado no setor ${ }^{214}$, bem como as deficiências de integração das firmas nacionais em relação ao padrão internacional. Destaca a necessidade de se recorrer ao arcabouço teórico de organização industrial que lida com custos de transação para analisar adequadamente as relações verticais na petroquímica - tendo em conta às limitações da teoria micro-econômica tradicional - para então decidir pela razoabilidade do acordo.

A operação foi então aprovada, por unanimidade, sob a condição de introdução de alterações em algumas cláusulas contratuais. Em primeiro lugar, redefinindo a localização (Paulínia, ao invés da região do Planalto Paulista), para esclarecer os limites geográficos do sistema de preferências pactuado. Além disso, a inclusão de uma disposição que estabelece que nenhuma cláusula do contrato poderá ser interpretada de modo a restringir a liberdade da Petrobrás participar de outros empreendimentos petroquímicos fora da região de Paulínia, seja na forma de fornecedora de insumos, seja como sócia, esclarecendo não haver qualquer tipo de preferência ou exclusividade em favor da OPP para além daquele acordo específico.

Os dois casos relatados acima, o AC 54/95 e o 189/97, são os únicos da amostra em que o CADE decidiu pela imposição de condições para aprovação. Nos demais, como se verá, as operações foram todas autorizadas sem restrições e por unanimidade, havendo eventuais discordâncias com relação ao valor da multa, quando intempestiva a apresentação da operação ao SBDC.

214 “O CADE não é o substituto do extinto Conselho de Desenvolvimento Industrial - CDI. De fato, o $C A D E$ é a antítese do CDI, ao regular o mercado fixando as regras da livre concorrência (de acordo com a lei), deixando as empresas livres para atuarem dentro desses limites, intervindo apenas quando alguma empresa conduz seus negócios contra os princípios do livre mercado”. 
Em 1999, a Odebrecht tentaria novamente uma estratégia para se firmar no mercado internacional. Desta vez, estabelecendo um acordo mundial de cooperação entre sua empresa OPP Petroquímica e a Borealis S/A, um global player de médio porte, visando complementação comercial e trocas de tecnologia para abastecimento dos setores automobilístico e elétrico (AC n. ${ }^{\circ}$ 08012.004012/1999-07). Com essa aliança, a Borealis passou a atender seus clientes globais instalados na América do Sul, utilizando a capacidade produtiva da OPP complementada com importações. A intenção da Odebrecht, por sua vez, era ingressar no mercado de especialidades químicas, porém pouco tempo depois, constatada a impossibilidade, optou por se concentrar na primeira e segunda geração da petroquímica ${ }^{215}$.

Foram considerados afetados pela operação os mercados nacionais de polipropileno e compostos de polipropilenos (este último correspondente a uma versão mais elaborada do primeiro), ambos produtos da segunda geração. Em julho de 2000 a operação foi aprovada pelo CADE por unanimidade e sem restrições, com base na avaliação de que era pequena a alteração da estrutura de oferta e, por essa razão, incapaz de gerar aumento do poder de mercado das requerentes. Mesmo a OPP sendo líder nesse ramo, a Borealis não atuava diretamente no mercado brasileiro, participando até então somente por meio de importações, e as importações correspondiam a pequenas fatias daqueles mercados.

Pouco tempo depois, a Borealis e a Odebrecht notificaram ao CADE uma segunda operação, desta vez de aquisição pela multinacional de $80 \%$ das ações representativas do capital social da OPP Polímeros Avançados S/A ("OPA”), detidas anteriormente pela OPP Petroquímica S/A, “OPP” (AC n. ${ }^{\circ}$ 08012.006110/2000-66). No parecer emitido pela SEAE, consta que

as requerentes informaram que a operação é parte da estratégia do grupo Borealis para reforçar sua posição como fornecedor do mercado, crescente e tecnologicamente avançado, de compostos de polipropileno para a indústria automobilística

e que a parceria representará um grande avanço também para a OPP, como fornecedora de resinas petroquímicas de classe mundial.

Assim como no processo anterior, foram identificadas sobreposições horizontais no mercado de compostos de polipropilenos, mas ponderou-se que a operação em tela

${ }^{215}$ Cf. G. R. SCHUTTE, Elo perdido...op. cit., p. 158. 
não promovia uma alteração significativa da estrutura de mercado. $\mathrm{O}$ mesmo ocorreu no que diz respeito à integração vertical entre o mercado de polipropileno fornecido pela OPP e o mercado de compostos de polipropileno no qual atua a Borealis, considerandose que a operação não alteraria o controle do setor que era preexistente a ela, sendo então aprovada sem restrições.

Nos termos do acórdão do CADE, que decide pela aprovação sem restrições:

Apesar da participação da OPP Polímeros Avançados no mercado nacional de compostos de polipropileno ser de 53\%, a participação das exportações da Borealis de compostos de polipropileno no consumo aparente foi de 0,1\% em 1999 (60 toneladas em 57.000) e de 0,3\% em 2000 (200 toneladas em 63.000). Dada a preexistência de controle vertical da OPP Petroquímica sobre a OPP Polímeros Avançados, os contratos de fornecimento da OPP Petroquímica à OPP Polímeros Avançados não acrescentam vínculos de integração vertical ao mercado. A operação não gera efeitos anticoncorrenciais, nem pode levar à dominação de mercados relevantes, nos termos do art. 54 da lei $n^{\circ}$ 8.884/94.

Em 1999, outro fato relevante viria a modificar o arranjo da petroquímica (sobretudo por tornar mais real o receio das empresas brasileiras de desnacionalização do setor): a operação mundial de aquisição dos ativos da Union Carbide pela Dow, que possibilitou $\mathrm{o}$ fortalecimento desta última no mercado brasileiro $\left(\mathrm{AC} \mathrm{n}^{\mathrm{o}}\right.$ 08012.007759/1999-91). A Dow já atuava no Pólo de Camaçari pela empresa EDN e também no Sul, em que possuía participação na Petroquímica Triunfo. A Union Carbide, por sua vez, tinha participações na PQU, Central Petroquímica do Estado de São Paulo. Além disso, as duas multinacionais eram detentoras mundiais da tecnologia de produção de um tipo de polietilenos (em forma gasosa) e proprietárias de patentes dessa tecnologia, o que as tornava ofertantes potenciais nos mercados das licenças de uso, mesmo que somente a Union Carbide efetivamente licenciasse as suas.

Esse aspecto levou as autoridades antitruste da União Européia e também dos EUA a imporem condições à operação, com vistas a restabelecer o grau de competição no mercado de tecnologia de produção de polietilenos. Com efeito, o mesmo fator levou a OPP, no Brasil, a se manifestar contrariamente à operação, alegando "graves efeitos anticompetitivos (...), não só no Brasil, como no Mercosul”. O argumento apresentado pela OPP era que, ao possuir participações nas empresas de primeira e segunda gerações nos quatro pólos petroquímicos do Mercosul, a Dow passaria a possuir também 
participações via acesso a tecnologias de produtos e processos, o que constituiria uma importante barreira ao ingresso e desenvolvimento de outros concorrentes. O CADE acabou decidindo pela aprovação da operação, considerando que as condicionalidades impostas pelas autoridades antitruste estrangeiras seriam suficientes para sanar eventuais efeitos nocivos à competição no território nacional.

Em 2000, os grupos Suzano e UNIPAR, a Petroquisa e o BNDES anunciaram a constituição do Pólo Gás-Químico do Rio de Janeiro (AC nº 08012.006452/00-86), empreendimento que já vinha sendo planejado desde 1987, com o objetivo de implementar nova tecnologia para possibilitar o aproveitamento do gás-natural na produção petroquímica, diminuir a dependência da indústria nacional em relação à nafta e, assim, também reduzir custos ${ }^{216}$. Tratava-se, portanto, de um passo importante rumo à consolidação do setor.

O modelo para implantação do novo pólo previa ampliação do espaço das empresas privadas e, aproveitando o debate em torno do Pólo de Paulínia (AC $\mathrm{n}^{\mathrm{o}}$ 189/97), mencionado anteriormente, sobre a forma de participação da Petrobrás ocasião em que a proibição desta participar da segunda geração fora derrubada - as empresas propuseram acabar de vez com a divisão entre primeira e segunda gerações, dando origem a uma única empresa, a Rio Polímeros, que atuaria nos dois segmentos ${ }^{217}$. Unipar e Suzano ficariam cada uma com $33,3 \%$ de participação nessa empresa, ao passo que a Petrobrás e BNDES ficariam com $16,7 \%$ cada.

A decisão do CADE para esse processo foi proferida em outubro de 2002, que identificou os produtos pertencentes ao mercado relevante para a operação como sendo o eteno (primeira geração de produtos petroquímicos), os polietilenos de baixa densidade, inclusive o linear, e polietileno de alta densidade (pertencentes à segunda geração). Neste caso foi mantida a posição anterior em relação à dimensão geográfica desses mercados, considerando-se o Mercosul como dimensão pertinente aos produtos de segunda geração, dada a possibilidade de importação da Argentina, e a região onde estará localizado o Pólo Petroquímico para os produtos de primeira geração.

O ato obteve aprovação sem restrições, tendo sido destacados os seus efeitos pró-competitivos sintetizados no parecer da SEAE:

\footnotetext{
216 O grupo Odebrecht também concorrera, mas teria acabado ficando de fora em virtude de desentendimentos com os outros grupos. G. R. SCHUTTE, Elo perdido...op. cit, p. 220.

${ }^{217}$ Divisão que, segundo G. R. SCHUTTE, "não existe em lugar nenhum do mundo e somente foi reproduzida e copiada do modelo tripé porque havia a necessidade de uma participação da Petrobrás na primeira geração e uma suposta proibição de ela participar da segunda”. Idem.
} 
único produtor de polietilenos totalmente integrado; escala internacional de produção de polietilenos em único local; gás natural como matéria prima com preço referenciado ao mercado norte-americano; menor investimento por tonelada produzida; menor custo operacional e tecnologia de última geração.

Cumpre observar, entretanto, que o Conselho fixou multa por intempestividade às requerentes, uma vez que o processo fora desencadeado por denúncia da empresa Copesul $^{218}$.

Um caso decisivo e que verdadeiramente desencadeou um processo mais amplo de transformação e concentração da estrutura de mercado da petroquímica nacional refere-se ao $\mathrm{AC} \mathrm{n}^{\circ}$ 08012.005799/01-92, que trata da aquisição dos ativos da antiga Central Petroquímica do Nordeste - Copene pelos grupos Odebrecht e Mariani. A operação que promoveu a reestruturação do Pólo de Camaçari, na Bahia, foi notificada ao CADE em 2001. Dos atos de concentração selecionados, é sem dúvida o mais importante e sensível ao questionamento acerca das justificativas ou "defesas" para a concentração econômica, uma vez que, ao possibilitar a formação da "Braskem", representava o sucesso da Odebrecht na direção de se constituir como a principal empresa nacional apta a concorrer no mercado internacional.

Com efeito, a operação em comento foi impulsionada por um fato alheio à petroquímica: a intervenção do Banco Central no Banco Econômico, em 1995, e a consequente liquidação de seus ativos. O Econômico controlava a Conepar, que por sua vez detinha o controle da Norquisa - empresa holding criada durante o governo Geisel que incorporava as ações ordinárias das empresas privadas do complexo petroquímico de Camaçari e dividia o controle da Central Petroquímica do Nordeste (Copene) com a Petroquisa. No entanto, após o leilão de desestatização realizado em agosto de 1995, a Conepar passara a controlar também a Copene.

Ocorre, todavia, que a intrincada rede de relações e disputas formada pelos principais atores envolvidos com o leilão - BNDES, Bacen, governo federal e as empresas diretamente interessadas no empreendimento, tanto de origem nacional (grupos Odebrecht, Ultra, Mariani e Suzano), como as estrangeiras Dow, Basf e Perez Companc - aliada aos efeitos macroeconômicos desfavoráveis provocados pelas crises asiática e russa, contribuíram para a demora de cerca de cinco anos para que o leilão de

${ }^{218}$ Vide Relatório e Voto do Conselheiro Miguel Tebar Barrionuevo. 
venda dos ativos da Conepar pudesse efetivamente ser concluído. A Odebrecht, associando-se ao grupo Mariani, saiu vencedora, notificando o CADE para análise dos efeitos concorrenciais da operação que viria a integrar as empresas de segunda geração do Pólo de Camaçari com a Central de matérias-primas (AC nº 08012.005799/01-92 referido acima).

Do ponto de vista da disciplina antitruste, o caso é complexo, uma vez que os grupos Odebrecht e Mariani passaram a ser os únicos produtores de insumos de primeira geração no Pólo de Camaçari - tais como o eteno, o buteno-1, o propeno, o butadieno, o benzeno e o paraxileno - e, ao mesmo tempo, tornaram-se concorrentes em determinados segmentos da segunda geração de outras empresas igualmente dependentes dos insumos de primeira geração produzidos no mesmo Pólo, tais como o polietileno e o polipropileno ${ }^{219}$.

De fato, as empresas de segunda geração Polibrasil, Politeno e Oxiteno (as duas primeiras controladas pelo grupo Suzano, a última pertencente ao grupo Ultra) manifestaram nos autos a preocupação acerca do potencial prejuízo à concorrência, em virtude do risco de fechamento de mercado. Alegam que a integração vertical via aquisição societária geraria incentivos para discriminação em relação aos agentes que não sejam parte da integração, para o quê argumentam tratar-se a planta da Copene uma “essential facillity".

As justificativas para realização do ato, apontadas pelas requerentes, seriam a obtenção de ganhos de escala e sinergias decorrentes da integração vertical entre as unidades empresariais de primeira e segunda geração, vez que a integração elevaria a capacidade de investimentos e geraria substanciais economias de escala e escopo, como diminuição da tributação em cascata, aumento de produtividade, melhoria de qualidade de bens e serviços e aumento da eficiência da área de pesquisa e desenvolvimento (“P\&D”). Além disso, as empresas também apontam o fato de se tratar de uma exigência de adaptação ao cenário de competição mundial na área petroquímica, caracterizado pela disputa entre grandes grupos integrados verticalmente.

Logo de início, é possível notar que os pareceres emitidos pela SEAE e pela SDE, apesar de convergentes quanto ao mérito (ambos sugerem a aprovação da operação sem restrições), o fazem sob uma linha de argumentação distinta. O voto do Conselheiro-Relator Roberto Pfeiffer, por sua vez, acaba mesclando ponderações

\footnotetext{
${ }^{219}$ Cf. Parecer SDE.
} 
contidas nesses pareceres, com o que a plenária do CADE decide por unanimidade autorizar a aquisição sem submetê-la a restrições, a despeito de ter acentuado expressivamente a concentração na petroquímica.

O parecer da SEAE, após delimitar o mercado relevante da operação, passa a avaliar as possibilidades de exercício de poder de mercado pelas requerentes. Conclui, então que

as concentrações horizontais e as integrações verticais observadas não são capazes de dar aos Grupos Odebrecht Química e Mariani qualquer possibilidade de exercício de poder de mercado nos mercados relevantes considerados, motivo pelo qual esta SEAE considera a celebração de um compromisso de desempenho totalmente desnecessária.(...) Não se pode pura e simplesmente partir da condição de monopolista de insumos da COPENE para concluir pela existência de restrição vertical e de infração à ordem econômica decorrente deste ato de concentração. Há que se verificar se os incentivos para que as restrições verticais se configurem estejam presentes.

Considera também que fixação de restrições à operação importaria em desvirtuamento da lei de defesa da concorrência, no sentido de proteger interesses privados, em detrimento da coletividade, sugerindo revisão da decisão proferida por ocasião do AC de n. ${ }^{\circ}$ 54/95, anteriormente apresentado. A esse respeito, reproduzem-se os termos do documento da SEAE:

à época, a estrutura societária dos pólos petroquímicos no Brasil apontava para a necessidade de um termo de compromisso na linha do que foi proposto. A visão que se tinha naquele momento da indústria petroquímica permitia tratar a primeira geração e a segunda geração da cadeia petroquímica como empreendimentos distintos, o que apontava para uma análise da concorrência no setor petroquímico ao nível da planta petroquímica. Passados alguns anos, esta SEAE considera que a concorrência no setor petroquímico nos dias de hoje se dá entre grandes empreendimentos petroquímicos verticalmente integrados e não ao nível da planta petroquímica. (...) A visão desta SEAE, portanto, é de que o Compromisso de Desempenho assinado por ocasião da decisão final do Ato de Concentração n. ${ }^{\circ}$ 54/95 engessa o desenvolvimento da COPESUL enquanto empreendimento petroquímico verticalmente integrado. $\mathrm{O}$ compromisso retira os incentivos para que os sócios controladores invistam no desgargalamento, uma vez que não poderão se apropriar do excedente de matéria-prima. 
Em relação ao mercado relevante, a SEAE considerou individualmente os mercados de cada produto envolvido na primeira e na segunda geração, e definiu, por separado, a área geográfica em que se dá a concorrência para cada um desses produtos. Assim, em relação aos produtos básicos, considerou ser regional (pertinente à área do Pólo) a dimensão adequada para eteno, propeno, butadieno, buteno-1 e benzeno. No que diz respeito ao tolueno e aos xilenos-mistos, a SEAE avaliou a dimensão internacional. Por fim, quanto ao MTBE, foram analisados dois cenários: o mercado nacional e o internacional. O dimensionamento dos mercados em que ocorreria concentração envolvendo os produtos de segunda geração, por sua vez, resultou internacional tanto para os polietilenos, como para os polipropilenos.

Tendo como base a amplitude da dimensão geográfica considerada pela SEAE, a análise do parecer, por um lado, argumenta pela descaracterização da possibilidade de exercício de poder de mercado; e, por outro, reconstitui a trajetória da indústria petroquímica nacional e suas fragilidades em relação ao padrão internacional - seu baixo grau de integração vertical - para sugerir a aprovação da operação sem restrições.

O parecer da SDE, diferentemente, enfatiza em mais de uma passagem que o exame do caso será realizado sob a ótica da eficiência econômica alocativa e do bemestar do consumidor, perspectiva esta não ressaltada no documento exarado pela SEAE, anunciando que:

a não ser que a eficiência econômica (ou alocativa) dos mercados seja reduzida com determinada integração vertical, não haveria porque intervir no negócio jurídico, nem tampouco autorização legal para tanto.

Em razão da condição de fornecedora monopolista de matérias-primas pela Copene, avalia a possibilidade de fechamento de mercados e a aplicabilidade da doutrina das "essential facilities", para definir seu posicionamento.

Assim, sob o prisma do bem-estar do consumidor a SDE acaba optando por uma delimitação de mercados relevantes por ela apontada como sendo mais conservadora, com vistas a verificar a consistência das dimensões de mercado definidas pela SEAE. Desse modo, considera dois cenários para os mercados de polietileno e polipropileno (pertencentes à segunda geração), um nacional, e o outro internacional (sendo que a 
SEAE considerou somente internacional). No que se refere às concentrações verticais, tratou dos mercados como tendo dimensão nacional.

A avaliação da SDE quanto aos efeitos da operação naqueles mercados onde houve concentrações horizontais concluiu pela inexistência de problemas concorrenciais: i) porque as atividades das requerentes estão em mercados relevantes distintos; ou ii) porque a participação conjunta das requerentes no mercado é baixa; ou iii) porque mesmo sendo elevada a participação conjunta, não há probabilidade de exercício de poder de mercado. Foram estes os casos para:

a) Mercado nacional de polietilenos - a avaliação feita neste âmbito foi de que as empresas responsáveis pela demanda de cerca de $38,86 \%$ da produção ofertada estariam dispostas a importar o produto caso o preço internacional fosse conveniente. Pelo lado da oferta, SDE avaliou que o impacto de uma eventual recusa de fornecimento de eteno pela Braskem seria pequeno. E também que a entrada da Rio Polímeros ( $\mathrm{AC} \mathrm{n}^{\circ}$ 08012.006452/00-86 abordado anteriormente), em 2004, ampliaria a oferta de polietileno, o que tornaria improvável o abuso de poder econômico pela Braskem, além da possibilidade cada vez mais crescente de importação da Argentina; e

b) Mercado nacional de polipropileno - uma parcela da demanda, por volta de $42,7 \%$ estaria disposta a importar o polipropileno, caso o preço fosse conveniente, na mesma linha argumentativa acima indicada.

No tocante às integrações verticais, a avaliação da probabilidade do aumento de custos de rivais, mediante o aumento de preço do insumo, bem como a viabilidade de fechamento de mercados para as concorrentes levou a SDE a concluir pela improbabilidade de exercício de poder de mercado. Nos mercados onde houvesse essa probabilidade, entretanto, considerou não subsistirem incentivos para a Braskem incorrer em tal prática.

A despeito disso, ponderou que ainda que ocorresse a prática, ela não acarretaria prejuízos ao bem-estar do consumidor:

Ainda que, por hipótese, a BRASKEM atuasse de maneira não racional, deixando de fornecer eteno e/ou propeno a algumas empresas na segunda geração da cadeia petroquímica, a concorrência nos mercados afetados pela operação não apresentaria alterações que - a despeito de significativas - se traduzissem em prejuízos ao bem-estar do consumidor. Isso porque a estrutura dos mercados relevantes envolvidos é tal, que mesmo uma estratégia de fechamento com aumento de custos dos 
rivais acabaria por diluir-se diante da possibilidade de que outros competidores (em outros pólos ou via importações, a depender do perfil dos adquirentes do polietileno e polipropileno), exerçam pressão competitiva.

Já o voto do Conselheiro-Relator Roberto Pfeiffer, o qual foi endossado por unanimidade pelo CADE, acompanhou a definição de mercado geográfico adotada pela SDE para o polipropileno, valendo-se de dois cenários possíveis: o nacional e o internacional. Para os polietilenos, diferentemente, constatando ter havido discussão em casos anteriores sobre a correta delimitação desses mercados (se internacional ou Mercosul), o Relator também analisou as duas possibilidades.

Como conseqüência, observa-se que na hipótese de dimensionamento mais alargado do âmbito de competição envolvendo esses produtos - ou seja, no mercado mundial - a participação das requerentes é pouco expressiva, descaracterizando-se, diante disso, a possibilidade de exercício do poder de mercado. De outro modo, na hipótese de ser nacional a dimensão a ser considerada em relação ao polipropileno, ou o Mercosul para os polietilenos, teve prosseguimento a verificação das condições para exercício do poder de mercado e seus efeitos horizontais e verticais. A partir desse ponto, o voto acompanha a argumentação apresentada pela SDE, no sentido de não restar comprovada nos autos a existência de prejuízos ao bem-estar do consumidor, possibilitando a aprovação irrestrita da operação.

Em complementação ao processo de reestruturação do Pólo de Camaçari, além da constituição da Braskem vêm ocorrendo também outras operações societárias que concentram e simplificam o famoso "nó" da petroquímica. Assim, por exemplo, a aquisição pela Braskem das ações de emissão da Trikem e da Polialden, empresas de segunda geração pertencentes à Mitsubishi (AC nº 08012.005811/2003-21). Pelo fato de se tratarem de empresas das quais a Braskem já possuía o controle, o CADE considerou que a operação não gerou efeitos na estrutura do mercado, aprovando-a sem restrições.

Outro caso apreciado pelo SBDC foi o AC de $n^{\circ}$ 08012.002974/2006-02, tendo como requerentes novamente a Braskem, a Itochu Corporation, SPQ Investimentos e partic. Ltda e Sumitomo Chemical Company, em que a Baskem adquiriu o controle da Politeno (atuante na segunda geração). O Conselheiro-Relator Paulo Furquim identificou os seguintes efeitos sobre a concorrência: a concentração horizontal (no mercado de polietileno, pertencente à segunda geração da cadeia petroquímica) e a 
integração vertical por acordo acionário, posto que a Braskem oferta eteno e buteno-1 que são insumos para produção daquele produto.

No que se refere à concentração horizontal, o Relator acolhe o parecer da SEAE, avaliando não vislumbrar prejuízos à concorrência advindos da operação, tendo em vista que a participação conjunta da Braskem e da Politeno não ultrapassa $2 \%$ do mercado internacional de polietileno. A respeito da relação vertical, anota o Conselheiro ser eficiente, considerando-se a redução de custos, para então prosseguir na mesma linha consagrada nas decisões anterior do CADE sobre a matéria, votando pela aprovação do ato de concentração sem restrições:

há motivos de eficiência econômica no movimento de ampliação do grau de controle pela Braskem sobre a Politeno. Resta indagar se há possíveis problemas de fechamento de mercado decorrentes da operação. Dadas as características do mercado de polietileno, cujo preço é determinado internacionalmente, não há benefício econômico a ser derivado do fechamento do mercado de venda de eteno ('input foreclosure') no Pólo de Camaçari, e conseqüente elevação de custos dos rivais efetivos ou potenciais. Essa estratégia apresenta o custo de recusa de venda sem a contrapartida do benefício de redução da concorrência e eventual elevação de preços. Como conseqüência, o fechamento do mercado de eteno não é provável. Do mesmo modo, não é plausível o fechamento do mercado de compra de eteno, visto que a Braskem é a central petroquímica do Pólo de Camaçari, não havendo rivais que pudessem ser objeto da estratégia. Em síntese, a operação não apresenta indícios de prejuízos à concorrência e justifica-se por resultar em estrutura de governança que, de modo consensual na literatura sobre o tema, é mais eficiente dadas as características do negócio petroquímico.

Com o fortalecimento da Odebrecht a partir da consolidação do Pólo de Camaçari e, paralelamente, a ampliação das participações da Petrobrás em algumas empresas da petroquímica (como no caso do AC n⿳0 08012.004506/04-01 em que ocorreu uma reorganização societária mediante a qual a Petroquisa ampliou participação anteriormente detida pela Dow Brasil S.A. na Petroquímica Triunfo S.A, também aprovado pelo CADE por considerar que a integração vertical decorrente não modificaria a estrutura já existente), foi possível retomar o projeto de constituição do Pólo de Paulínia.

Desta vez, em 2005, Braskem e Petroquisa submeteram à apreciação do CADE a constituição de um joint venture para desenvolverem em conjunto um projeto de 
construção e operação de uma planta para a produção de polipropileno naquela região (AC $n^{\circ}$ 08012.005598/2005-19). O mercado relevante para a operação foi delimitado como sendo regional para o propeno (matéria-prima) e, no caso do polipropileno, foram analisados dois cenários: o nacional e o internacional. Neste último, a estrutura de mercado foi identificada como sendo pulverizada, razão pela qual não haveria condições para exercício de poder de mercado pelas requerentes. No caso de ser nacional o mercado, a despeito da operação gerar concentração, considerou-se não haver substancial alteração da estrutura anteriormente existente, com base nos seguintes argumentos: a) a fábrica nova só entraria em operação em 2007, razão pela qual seria pouco provável que aumentasse significativamente a parcela de mercado da empresa; b) mesmo que aumentasse, sua concorrente, a Polibrasil, tem condição de contestar essa posição e, por fim;

c) também não se pode afirmar haver nexo causal entre a alta participação da Braskem no mercado e a operação em tela, visto que a parcela de mercado já era elevada antes da operação ocorrer, fator que não sofrerá grande alteração ${ }^{220}$.

No que tange à relação vertical (entre propeno e polipropileno), esclarece o parecer da SEAE:

Não há também que se falar em integração vertical em relação à Braskem, uma vez que o mercado de propeno é regional, e o fornecimento para a nova planta deverá ser efetuado mediante a celebração de contrato de fornecimento para a nova demanda de propeno, envolvendo acréscimo de produção de propeno pelas Refinarias de Paulínia - REPLAN e de Henrique Lage - REVAP. Ressalte-se que este novo contrato, que ainda se encontra em fase de negociação, refere-se a uma nova demanda e não afeta os contratos de propeno em vigor. (...) No tocante à Petroquisa, ainda que se vislumbre uma integração vertical na cadeia produtiva do setor petroquímico, essa integração é limitada uma vez que o mercado de fornecimento de propeno é regional. A integração vertical se for considerada, ficará limitada à região de Paulínia, em São Paulo.

${ }^{220}$ Cf. Voto do Conselheiro-Relator Ricardo Cueva. 
Segundo o Conselheiro-Relator, a possibilidade de fechamento de mercado não ficou comprovada, uma vez que há no mercado regional outra empresa ofertante do insumo propeno (a principal fornecedora é a PQU). "Dessa forma, mesmo que a Petrobrás decidisse fechar o mercado de propeno, os consumidores teriam outra alternativa para adquirir o produto" ${ }^{, 21}$. Assim, concluiu-se pela aprovação da operação sem restrições.

\section{Discussão}

A exposição recém realizada em relação a uma amostra de atos de concentração levados ao CADE envolvendo a petroquímica nos últimos anos permite visualizar alguns dos movimentos efetuados pelos atores desse setor a partir da mudança do marco regulatório na década de 1990. Houve ingresso de empresas estrangeiras e aquisição de ativos por elas, visando ampliar suas participações no mercado nacional, e também concentração em torno de alguns grupos nacionais, com destaque para a formação da Braskem.

Além disso, o relato acima também possibilitou observar que a aplicação das normas de defesa da concorrência no Brasil resultou suficientemente flexível a ponto de não ter representado obstáculo à necessidade de reorganização e concentração econômica do setor. Vale dizer, se por um lado houve algumas tentativas de parte do grupo Odebrecht até que conseguisse, de fato, ampliar de maneira expressiva sua participação nessa atividade, por outro lado, isso não teria sido possível sem que o CADE modificasse sua interpretação acerca da dinâmica competitiva na petroquímica.

Os dois casos que ilustram o contraste de interpretações são o AC n ${ }^{\circ}$ 54/95 e o AC nº 08012.005799/2001-92, referente à reestruturação do Pólo de Camaçari. Neste último, a necessidade de mudança foi enfatizada no parecer da SEAE, mencionado anteriormente, segundo o qual a concorrência no setor não deveria ser analisada ao nível da planta petroquímica (como ocorrido no primeiro caso), mas sim, entre estruturas empresariais integradas verticalmente e atuantes no mercado mundial.

A ampliação do campo de visão, por sua vez, teve reflexo na delimitação geográfica do mercado considerado relevante para as operações envolvendo polipropileno e polietilenos. Assim, por exemplo, enquanto no AC 54/95 considerou-se

\footnotetext{
${ }^{221}$ Idem.
} 
o Mercosul, no caso da constituição da Braskem o mercado foi considerado internacional.

Outro aspecto digno de nota, nos casos analisados, é a riqueza de informações contidas nos pareceres da SEAE e SDE acerca da caracterização do setor e sua dinâmica competitiva, bem como sua trajetória no país, o que denota, com efeito, a real abertura das normas antitruste à complexidade dos mercados que pretendem disciplinar, de forma que no procedimento das autoridades estejam incluídos mecanismos que permitam o aprendizado dos técnicos acerca das especificidades de um determinado ramo.

Desse modo, verificou-se que a autoridade antitruste brasileira tende a compreender o empreendimento petroquímico, como salientou o Conselheiro Paulo Furquim no trecho acima transcrito, como internacional, caracterizado pela necessidade de integração entre as firmas, razão pela qual todos os casos levados ao CADE foram aprovados, tendo havido imposição de condições em apenas duas ocasiões.

Essa tendência acentuada à concentração do setor (que permitiu, como observado, a consolidação do grupo Odebrecht no Pólo da Bahia) se confirma, no Brasil, diante dos últimos acontecimentos envolvendo a realização de importantes operações que modificam as estruturas dos Pólos localizados nas regiões sul e sudeste. Essas operações, apresentadas ao CADE bem recentemente - e, portanto, ainda não julgadas - fortalecem ainda mais as posições do grupo Odebrecht (Braskem) e também ampliam a participação da Unipar (neste caso, mais especificamente na região do $\mathrm{ABC}$ ) e da Petrobrás na petroquímica nacional, e por isso vêm suscitando polêmicas.

Em março de 2007, a Petrobrás e os grupos Ultra e Braskem anunciaram a realização de um consórcio para a compra do grupo Ipiranga, detentor da maior rede privada de postos do país e de $29 \%$ da Copesul, a central de matérias-primas do pólo petroquímico de Triunfo, RS (ACs nº 08012.002813/2007-9, 08012.002818/2007-14 e 08012.002820/2007-93). A operação levou a Braskem ao controle desta última ${ }^{222}$. Além dos efeitos no mercado de produtos petroquímicos, o acordo afetou também o refino de petróleo e a distribuição de combustíveis, áreas nas quais operava a Ipiranga.

Embora tenha sido apontado que a operação foi muito bem montada para não enfrentar problemas junto às autoridades de defesa da concorrência ${ }^{223}$, o aumento da

\footnotetext{
222 Gazeta Mercantil, 19/03/2007, A-4.

223 "Petrobrás, Ultra e Braskem fatiam Ipiranga", in Folha de São Paulo, 20/03/2007. De acordo com a reportagem, os representantes das três empresas declararam não estarem preocupados com a análise do
} 
concentração no setor foi recebido com atenção pelo CADE, levando à homologação, em 18 de Abril deste ano (2007), de uma medida cautelar que suspendeu temporariamente os efeitos da compra da Ipiranga pela Braskem, Petrobrás e Ultra, em relação a três aspectos: (a) a Petrobrás não poderia participar das decisões estratégicas na Copesul e na distribuição de combustíveis da Ipiranga nas regiões Norte, Nordeste e Centro-Oeste; b) a Braskem não poderia participar de decisões estratégicas na Ipiranga Petroquímica (controladora da Copesul); e c) a Ipiranga não poderia transferir novos ativos na petroquímica, sendo obrigada a mantê-los numa unidade jurídica independente. $\mathrm{O}$ argumento apontado pelo CADE para a adoção da medida suspensiva foi o de evitar o "fato consumado", isto é, que a operação se tornasse irreversível, visto que notificada apenas posteriormente a sua realização ${ }^{224}$.

Assim, em nota à imprensa, CADE, SEAE e SDE manifestaram que

a medida cautelar não tem o condão de proibir o fechamento da operação ou a transferência de ativos entre empresas afetadas. As medidas sugeridas referem-se apenas a regras de governança corporativa que visam a evitar o compartilhamento de informações de valor comercial e estratégico entre concorrentes, preservando as relações de concorrência nos mercados afetados pela operação até o julgamento do mérito pelo CADE. (...) Todavia, note-se que a análise da operação ainda se encontra em estágio preliminar. $\mathrm{O}$ fato de haver um pedido de medida cautelar não significa que a operação sofrerá efetivamente restrições quando de sua apreciação pelos órgãos de defesa da concorrência. Ao final de sua análise, a SDE emitirá parecer em instrução conjunta com a SEAE e remeterá o caso ao CADE para julgamento final $^{225}$.

Os pareceres referidos ainda não foram publicados, mas alguns dias depois foi anunciada a flexibilização de alguns dos pontos que integravam a medida cautelar, com base em informações fornecidas pelas empresas requerentes. As modificações pertinentes à petroquímica decorrem da assinatura, por parte da Braskem, de um Acordo de Preservação e Reversibilidade da Operação, no qual se compromete a manter

CADE, como manifesta o presidente da estatal: "A divisão do mercado de distribuição de combustíveis nos dá uma certa tranqüilidade na questão da concentração".

224 "CADE aprova restrições à compra da Ipiranga", in Valor Econômico, 19/04/2007.

${ }^{225}$ Nota publicada na Agência de notícias do Ministério da Justiça, acesso em 17/04/07, no endereço http: //www.mj.gov.br/noticias/2007RLS17040407nota.htm. 
separados seus ativos dos da Ipiranga, ficando, assim, a Braskem "excluída" do rol de restrições impostas pelo $\mathrm{CADE}^{226}$.

Estabelecido o domínio da Braskem nas regiões nordeste e sul, restava ainda definir o destino da petroquímica no Sudeste, região dividida entre a Suzano Petroquímica e a Unipar. A união entre estas duas, que já vinha sendo discutida há alguns anos, teve início com a compra da Suzano pela Petrobrás (AC $\mathrm{n}^{\circ}$ 08012.011068/2007-71), surpreendendo a Odebrecht, que sabidamente tinha interesse no empreendimento. A medida adotada pela Petrobrás desencadeou reações já enraizadas em alguns segmentos do setor receosos sobre a possível "reestatização". A esse respeito, a Petrobrás viria a manifestar que se encontrava em negociações para realizar a fusão da Suzano com a Unipar em uma nova empresa, que viria a ser chamada de Companhia Petroquímica do Sudeste, a qual permaneceria sob controle da Unipar. Esta última, por sua vez, fortaleceu-se também por meio da aquisição das participações da Dow na PQU e na SEP (AC nº 08012.009856/2007-06).

O novo desenho da petroquímica nacional foi selado com a redefinição do papel da Petrobrás no setor, mediante a celebração de acordos com a Braskem e a Unipar. No primeiro caso, a estatal amplia sua participação na empresa privada de 6,8\% para 25\%, ao passo que a Braskem passa a deter 100\% do empreendimento de Paulínia, 100\% da Central Copesul, $100 \%$ da Ipiranga Petroquímica e 33,6\% da Petroflex, fabricante de borracha sintética. No segundo caso, a constituição de uma nova empresa, a Companhia Petroquímica do Sudeste, viria a ocorrer mediante a união dos ativos da Unipar (PQU, Rio Polímeros, Polietilenos União e UDQ - Unipar Divisão Químicas) e Petrobrás (que reuniria os ativos adquiridos da Suzano). A Unipar torna-se detentora de $60 \%$ do negócio, enquanto a estatal fica com os $40 \%$ restantes - mesma relação existente entre a Braskem e a Petrobrás quando da negociação inicial da Ipiranga ${ }^{227}$.

Da redefinição do tripé em torno do qual passou a se organizar a indústria petroquímica brasileira - desta vez, sustentado por duas grandes empresas nacionais (sendo, notadamente, a Braskem a principal delas, dado seu faturamento equivaler ao dobro do da Unipar) e o fortalecimento da presença estatal - ressurgiu o debate sobre a concentração do mercado e seus efeitos sobre a concorrência.

\footnotetext{
226 "CADE revê sua decisão contra venda da Ipiranga", in Folha de São Paulo, 26/04/2007, caderno Dinheiro.

227 "Investimento em petroquímica deve crescer 220\%, diz BNDES", in Folha de São Paulo, 16/08/2007, caderno Dinheiro.
} 
Embora muitos tenham se manifestado em favor desse processo, por representar um passo importante em direção ao aumento da competitividade das firmas brasileiras, houve também quem questionasse o novo modelo e a "escolha dos vencedores", apontando ter havido substituição do monopólio estatal pelo monopólio privado, sob estímulo e apoio da Petrobrás. Nessa direção, vejam-se as declarações dadas pelo sócio da Petroquímica Triunfo no editorial do jornal O Estado de São Paulo de 30/11/2007 (“Concentração na Petroquímica") ${ }^{228}$.

De fato, como observado anteriormente, a cadeia de produção petroquímica, marcada pela alta dependência entre os segmentos de primeira e segunda geração, acaba estabelecendo um mercado cativo para as centrais de matérias-primas e, por conseguinte, traz em si o risco do exercício abusivo do poder de mercado. Há sentido, por tanto, na preocupação de que com o aumento da concentração Braskem e Unipar encontrem incentivos para a imposição de preços ou recusa de fornecimento às empresas que não estejam integradas às centrais por elas controladas. Some-se a isso a relatividade da afirmação de que o mercado é contestável, considerando que há significativas barreiras à entrada no setor, o que torna ainda mais complexa a avaliação dos processos recentemente submetidos ao SBDC.

Há, em contrapartida, a defesa do presidente da Petrobrás, José Sérgio Gabrielli, para quem a concentração não representará dano à concorrência no setor, pois "a tendência é a Braskem e a Unipar competirem e crescerem”. Sustenta, ainda, que em sendo minoritária, a Petrobrás não interfere nas decisões concorrenciais das empresas ${ }^{229}$. Além disso, a atuação da Petrobrás nesse movimento de reorganização do setor tem sido referendada pelo governo federal. Segundo o jornal Folha de São Paulo (05/12/2007) ${ }^{230}$,

Lula classificou a ação da Petrobrás no setor petroquímico como um momento histórico. 'A gente poderia colocar no nosso

\footnotetext{
${ }^{228}$ Referindo-se à constituição da nova companhia do sudeste e à polarização entre o sócio da Triunfo (Boris Gorentzvaig) e a postura defendida pela Petrobrás, o texto conclui: "É difícil decidir quem tem razão nessa controvérsia. Mas têm sentido as perguntas formuladas por Boris Gorentzvaig, e o governo - que ele acusa de favorecer o Grupo Odebrecht - deve esclarecimento à sociedade. O Presidente da República (...) deve responder se há uma política oficial de reestruturação do setor petroquímico e se, nesse caso, a Petrobrás é a executora de uma estratégia oficial. Se a resposta for negativa, então restará a responsabilidade da Petrobrás como empresa líder de um processo de concentração. Nesse caso, os órgãos de defesa da concorrência, como a Secretaria de Defesa Econômica (sic) e o Cade, não teriam algo para dizer sobre o assunto?”.

229 "R $\$ 10$ bi dão nova cara à petroquímica - Petrobrás, Braskem e Unipar surgem como líderes na petroquímica, ao final de três negociações bilionárias concluídas ontem”, in O Estado de São Paulo, p. b12.

230 "Lula quer ação maior em petroquímica" - Caderno Dinheiro.
} 
calendário que o setor pode ser contado antes desta data e depois desta data. Porque, se o Geisel tinha dado o pontapé inicial, eu acho que, neste momento, nós estamos marcando o gol'.

Por fim, a matéria publicada na Folha de São Paulo de 01/12/2007 ("Para especialista, acordos da Petrobrás refletem decisão política para o setor”, termina de forma provocativa, apontando para a possibilidade de intervenção das autoridades de defesa da concorrência, alterando o novo arranjo do setor: “(...) Sobre a Braskem recairá o risco de se tornar 'grande demais' à vista do CADE (...), que pode barrar a operação".

Em síntese, o exame geral do processo de reestruturação da petroquímica que foi apreciado pelas autoridades de defesa da concorrência evidenciou ter havido aceitação dos argumentos em favor da concentração empresarial como imperativo para o aumento da competitividade do setor, a partir de uma evolução dos critérios adotados pelo CADE (em especial, o dimensionamento do mercado relevante). Além disso, foi possível observar que embora esse movimento tenha levado cerca de quinze anos para ser concretizado, esse fato não responde a uma condição imposta pela aplicação muito rigorosa da lei antitruste, mas sim à complexidade de disputas e conflitos de interesses envolvidos, que acabou agravada com a retirada do poder público das atividades de arbitragem e coordenação.

\section{Considerações finais}

Este capítulo percorreu os principais movimentos empreendidos na indústria petroquímica brasileira em direção a sua reorganização, a partir das reformas regulatórias da década de 1990, registrando sua passagem pelo Sistema Brasileiro de Defesa da Concorrência. A despeito de esse processo ter conduzido ao aumento significativo da concentração econômica no setor - destacando-se as posições de dois grupos fortes, a Braskem e a Unipar - todos os casos foram aprovados pela autoridade antitruste.

Apenas em dois dos casos que integram a amostra selecionada para análise foram estabelecidas condições para a aprovação (esses casos coincidem com a fase inicial do CADE, em que, segundo Gesner de Oliveira, ex-presidente do Conselho, exigia-se comprovação da eficiência da operação para que fosse aprovada; depois, 
mudança de paradigma e amadurecimento institucional). Os demais atos de concentração envolvendo a petroquímica foram todos aprovados sem restrições.

Observou-se que entre os fatores que orientaram essas decisões consta a delimitação do mercado relevante para os principais produtos de segunda geração polipropileno e polietilenos - ter sido considerada internacional em diversas ocasiões (às vezes no âmbito do Mercosul, às vezes no cenário mundial). Notou-se também que em diversos pareceres houve registro acerca do padrão mundial de competição na petroquímica ser marcado por grandes empresas integradas verticalmente, como também do baixo grau de integração das firmas brasileiras vis-à-vis a dinâmica internacional. Essa mudança de enfoque permite visualizar a importância da evolução dos critérios de aplicação da lei antitruste pelo CADE, à luz dos desenvolvimentos do setor.

Paralelamente às sucessivas operações levadas às autoridades antitruste envolvendo empresas privadas, a Petrobrás passou a ampliar suas participações no setor, associando-se posteriormente às duas grandes empresas resultantes do processo de reestruturação. Verificou-se, assim, a retomada da proposta vencida no período da privatização, que era aumentar a participação da Petrobrás nas centrais e formar um forte grupo privado nacional com a composição entre Suzano, Ipiranga e Unipar.

Em relação a estes casos mais recentes, que se encontram atualmente sob exame das autoridades de defesa da concorrência, embora não seja possível prever o posicionamento do Conselho, o pronunciamento público do presidente da República denota uma política de apoio ao novo arranjo do setor, possibilitando a formação de empresas fortes, aptas a concorrer internacionalmente. Assim, não parece haver sinais de que as operações venham a ser efetivamente obstruídas em virtude da garantia da concorrência no plano interno.

Em suma, a análise dos dados apresentados neste capítulo permitiu observar a importância da evolução dos critérios de aplicação da lei 8.884/94 em relação aos atos de concentração envolvendo a petroquímica, sem o que a readequação às exigências internacionais de competição não teria sido possível. Por outro lado, o fato desse processo de reorganização das empresas ter demorado cerca de quinze anos, após o que houve um retorno à proposta vencida no período das privatizações, traz à tona outros temas importantes. Em especial, se esse movimento poderia ter sido acelerado de algum modo e, em caso afirmativo, que outro arranjo jurídico-institucional teria sido adequado. Estas questões remetem à problemática levantada no capítulo inicial deste 
trabalho a respeito do modelo de instituições mais adequado para os países em desenvolvimento e do papel do direito concorrencial nesse processo, assunto que será retomado nas conclusões apresentadas na próxima seção. 


\section{CONCLUSÕES}

No quadro das discussões sobre a adequação do modelo de política de defesa da concorrência difundido durante os anos 1990 às especificidades das economias em desenvolvimento, este trabalho investigou a aplicação do direito antitruste brasileiro no contexto particular da indústria petroquímica nacional.

Para tanto, além da revisão dos conceitos e práticas da regulação antitruste nos países centrais, em perspectiva histórica, e de alguns dos desafios apontados pela literatura acerca da sua aplicação em economias em desenvolvimento, foram descritos os traços gerais da matéria no ordenamento jurídico brasileiro, com foco no controle da concentração econômica, passando-se então ao estudo dos casos examinados pelo Conselho Administrativo de Defesa Econômica (CADE).

Observou-se, assim, que embora as trajetórias nacionais de formulação e aplicação da disciplina concorrencial nos Estados Unidos, Europa e Japão tenham sido diferenciadas ao longo de seus respectivos processos de industrialização - alternando períodos de maior e menor vigor, priorizando diferentes objetivos e articulando-se com outros instrumentos de política direcionados à atividade econômica - as práticas e critérios utilizados para aferir abusos nos mercados têm convergido progressivamente nos últimos anos.

Particularmente, no contexto da onda de reformas disseminadas pelas economias capitalistas na década de 1990, que resultaram em ampliação dos limites dos mercados e intensificação da concorrência, assim como diminuição da esfera de influência dos estados no âmbito econômico, o argumento em torno da necessidade de convergência foi levado ao extremo, e colocado aos países em desenvolvimento como "o único caminho possível". Ao lado da valorização do mercado como instância mais eficiente de coordenação da atividade econômica e da concorrência como principal fator dinamizador da economia, as críticas à ingerência estatal deram embasamento aos processos de abertura, desregulação e privatizações, colocando em destaque a necessidade de ação do Estado para assegurar as condições de competição, por meio da prevenção e repressão aos abusos de poder econômico.

Em matéria de defesa da concorrência, propagou-se a visão de que o modelo de política adequado aos países em desenvolvimento deveria seguir as tendências mais 
contemporâneas dos países centrais: priorizar a geração de riquezas (eficiência econômica em sentido estático) e o bem-estar do consumidor (em termos de preços acessíveis), estabelecendo, desse modo, parâmetros comuns para a competição nos diferentes setores da economia, sem criar distinções entre eles, nem tampouco ceder espaço para mecanismos de política industrial que não aqueles centrados na promoção e proteção da concorrência (para evitar distorções no sistema de preços).

Essa concepção, sustentada pelos organismos internacionais, foi questionada por alguns autores $^{231}$ que apontaram para os riscos de uma aplicação rigorosa da legislação concorrencial, apoiada no referencial econômico ortodoxo, levar a resultados indesejáveis do ponto de vista das necessidades das economias em desenvolvimento, especialmente no que se refere ao controle das estruturas de mercado.

Por um lado, expressaram a preocupação de que a vinculação muito estreita ao referencial de concorrência perfeita (em que a competição se dá entre uma pluralidade de unidades econômicas atomizadas, isto é, incapazes de individualmente influenciar as condições de oferta e demanda) poderia levar à proibição de operações de concentração e integração indispensáveis à consolidação de alguns setores para que possam concorrer em nível internacional.

Por outro lado, apontaram a necessidade dos países em desenvolvimento completarem seus processos de industrialização, para o que não deveriam prescindir do recurso a outros instrumentos de coordenação e articulação da atividade econômica adequados para atender carências específicas de cada setor, os quais deveriam ser integrados aos objetivos da disciplina antitruste - ao invés de desarticulados ou substituídos pela promoção e proteção da concorrência, tal como proposto no bojo das reformas dos anos 1990. Estas idéias também foram defendidas em trabalhos de alguns autores brasileiros ${ }^{232}$.

Tomando como ponto de partida estas considerações, este trabalho investigou o funcionamento da instituição de defesa da concorrência no Brasil e a sua atuação no setor petroquímico. Buscou-se analisar a resposta dada pelas autoridades na matéria à necessidade premente de concentração e integração entre as firmas, condição inafastável para a sua sobrevivência no ambiente econômico internacionalizado.

\footnotetext{
${ }^{231}$ Entre outros, os já citados H. J. CHANG, A. SINGH, R. DHUMALE \& A. SINGH e A. PHAM.

${ }^{232}$ Como L. COUTINHO (Política de Concorrência...op. cit), M. L. POSSAS et aliii (Política Antitruste sob um Enfoque...op. cit) e A. B. SICSÚ \& M. O. L. MELO (Competitividade, Política de Defesa da Concorrência e...op. cit).
} 
O estudo de caso permitiu extrair considerações específicas sobre a petroquímica, e outras de ordem mais geral. No primeiro grupo, foi possível concluir que ainda que sob o predomínio de um referencial teórico estático no tratamento de problemas concorrenciais, a disciplina antitruste não representou restrição ou obstrução à concentração da petroquímica no país. Em relação a esse setor, o direito brasileiro mostrou-se suficientemente permeável à necessidade de concentração e integração dos players para concorrerem no cenário globalizado, ainda que não tenha sido objeto de flexibilização mais expressa ou direta, como em outros ordenamentos (via isenção, por exemplo).

O exame dos processos levados ao SBDC indica que um dos elementos que possibilitou a aprovação dos casos (e que denota, justamente, a abertura do sistema) foi a evolução da definição do mercado relevante para as operações. Assim, as manifestações dos Conselheiros do CADE, bem como os pareceres emitidos pela SEAE e SDE passaram a expressar que a apreciação dos riscos potenciais de restrições ou prejuízos à concorrência tomaria como ponto de partida o mercado internacional como locus da competição em relação a muitos dos produtos petroquímicos (em alguns casos, o Mercosul, em outros o mercado mundial como um todo) sobretudo em relação aos produtos de segunda geração.

Além disso, mesmo nos mercados onde se identificou uma concentração significativa de poder de mercado, considerou-se a possibilidade de importação de produtos estrangeiros - ou seja, novamente a concorrência internacional - como um dos fatores importantes a inibir ou descaracterizar a possibilidade ou probabilidade de exercício desse poder econômico com vistas a prejudicar a competição interna (caso da Braskem, por exemplo). Outro fator avaliado foi a razoabilidade da prática de fechamento de mercado em conseqüência da concentração vertical entre as centrais de matérias-primas (monopolistas) e as empresas de segunda geração de produtos petroquímicos. No caso da constituição da Braskem, novamente, a argumentação da SDE - acolhida pelo Conselheiro-Relator do processo - foi de que a estrutura acionária das empresas (marcada, historicamente, pela existência de participações cruzadas), não traria incentivos para a realização de tal prática.

Desse modo, nota-se que a tomada de decisões pelo SBDC não descurou das especificidades da conformação da petroquímica no Brasil. Assim, os votos e pareceres analisados expressam diretamente a avaliação acerca do baixo grau de integração das firmas brasileiras vis-à-vis o padrão internacional, e que os atos de concentração 
envolvendo esse setor no país enquadram-se numa tendência mundial. Vê-se também a ponderação de que houve um processo histórico que conduziu à fragmentação das participações acionárias das empresas atuantes nesse ramo e que o movimento atualmente em curso de reorganização dos principais atores da petroquímica é reflexo dessa trajetória particular.

Igualmente, é importante destacar que o fato de a indústria petroquímica nacional estar se concentrando com aprovação do CADE, apresentando como resultado o fortalecimento das posições de comando de duas empresas privadas - a Braskem e a Unipar - embora tenha suscitado questionamentos sobre a efetividade da defesa da concorrência no país, não deve ser assim compreendido. Ao contrário, o que se constata é justamente a sua vitalidade e permeabilidade da aplicação da lei a uma pluralidade de objetivos possíveis, dentre os quais a própria consolidação da indústria nacional (como vem ocorrendo no caso da petroquímica), ainda que o discurso dominante na matéria em geral focalize a concorrência, a eficiência econômica e o bem-estar do consumidor.

Entretanto, isso não significa que essa flexibilidade na aplicação da disciplina antitruste esteja do mesmo modo presente no tratamento de outros setores da indústria que, tal como o petroquímico, enfrentem a concorrência internacional com grandes empresas. Nesse sentido, é preciso notar que a preocupação com um excessivo estreitamento ao referencial neoclássico, priorizando a noção de bem-estar do consumidor, é legítima, pois representa de fato um risco em potencial para determinados setores que talvez não tenham o mesmo valor estratégico da petroquímica, nem contem com um ator do porte da Petrobrás.

Como mencionado, o estudo do caso da petroquímica brasileira também trouxe elementos para algumas considerações de ordem mais geral acerca do direito da concorrência no Brasil e do papel que esse mecanismo de regulação desempenha nas economias em desenvolvimento.

Em primeiro lugar, um dos aspectos observados é o distanciamento entre a referência abstrata do modelo de concorrência perfeita e a realidade dos mercados, como visto em relação às características estruturais da petroquímica. Isso reflete na dinâmica da disciplina da concorrência, não apenas no Brasil, mas também nos demais países cuja experiência foi abordada no primeiro capítulo.

Com efeito, essa distância entre a abstração dos modelos e a realidade concreta dos mercados é justamente o que confere maior importância aos atributos de abertura e flexibilidade das regras de direito da concorrência, representadas pela utilização de 
categorias jurídicas cujo sentido será completado pelo intérprete, em cada caso concreto, com recurso ao juízo de razoabilidade para aferir a ilicitude da eventual restrição à competição. Estes recursos possibilitam, em princípio, orientar a aplicação da legislação antitruste às diferentes características dos setores da economia e às transformações neles ocorridas, podendo então atender objetivos variados de política considerados importantes para cada área, em um determinado momento histórico, sem que isso represente necessariamente um desvirtuamento na aplicação da lei.

Essa abertura do sistema constitui um elemento de especial valor para os países em desenvolvimento: sendo a mudança o traço fundamental dos processos de desenvolvimento econômico e industrial, a possibilidade de adaptação e adequação da aplicação da norma à transformação da economia (tal como observado no caso da petroquímica nacional, em relação à definição de mercado relevante) mostra-se crucial, evidenciando tratar-se de uma instituição onde há espaço e possibilidade para a evolução e a aprendizagem.

Ainda em atenção à perspectiva dos países em desenvolvimento, é preciso notar que se, com efeito, as regras de direito da concorrência têm em seu favor os traços de abertura e flexibilidade, por outro lado - e aqui, concretamente, seguindo uma tendência contemporânea das políticas dos países centrais - elas estabelecem critérios comuns para avaliar as condições de competição em setores e atividades que apresentam diferenças significativas entre si. Esse fator acaba impondo a esse instrumento de regulação o desafio de ser flexível o bastante para responder às particularidades de cada setor e/ou caso concreto e incorporar diferentes sentidos.

Assim, se no caso da petroquímica a necessidade de concentração era premente e acabou sendo acolhida pelas autoridades de defesa da concorrência, há atividades em que, ao contrário, proteger a competição exige assegurar a pluralidade de opções; em outras, a garantia de lucros monopolísticos são condições indispensáveis para uma configuração eficiente e focada em inovação. A variedade de situações, que é ainda mais acentuada nas economias em desenvolvimento, potencializa os riscos da aplicação horizontal da legislação concorrencial levar a resultados indesejáveis.

Esse traço de horizontalidade da política de concorrência, tal como levada adiante no Brasil, constitui, de fato, um dos aspectos criticados por alguns autores que apontam a necessidade das legislações apresentarem expressamente diretrizes para setores determinados. Com essas medidas, espera-se poder mitigar o risco de que 
interpretações demasiadamente restritivas da lei possam, por exemplo, obstruir a formação de grandes empresas mediante um controle das concentrações econômicas.

Todavia, abrir exceções à aplicação da norma - estabelecendo setores isentos ou coordenando-a com outros instrumentos ou objetivos de política - importaria em admitir as limitações da concorrência, e da sua disciplina jurídica, como instrumentos preponderantes de regulação dos mercados, contrariando as principais recomendações de política destacadas em âmbito internacional nos anos 1990.

Passados mais de uma década desde a realização destas reformas no Brasil, e havendo o país acumulado experiência e maturidade institucional no tratamento de questões concorrenciais, há mais elementos (e também mais consistentes) para analisar o espaço e o alcance da disciplina antitruste. Sem descurar da importância e utilidade desse mecanismo de controle sobre a atividade econômica (vez que a existência de estratégias empresariais anticompetitivas é real e acarreta prejuízos sobre o bem-estar), seu papel não deve tampouco ser superestimado ${ }^{233}$. O direito da concorrência complementa, mas não substitui outros instrumentos de política pública necessários à coordenação dos mercados e à promoção da competitividade ${ }^{234}$.

O presente estudo sobre a aplicação do direito concorrencial, circunscrito à indústria petroquímica brasileira, reforça essa percepção, corroborando as idéias já manifestadas em outros trabalhos que abordam a relação entre defesa da concorrência e política industrial $^{235}$. Se, por um lado, desonera a regulação da concorrência com respeito à desconfiança de que poderia obstruir o processo de concentração em alguns setores, por outro lado, a lentidão com que esse movimento de concentração foi concretizado na petroquímica evidencia a falta de coordenação e articulação em torno de uma estratégia para o setor. Explicita, portanto, a lacuna deixada pela retirada do setor público anteriormente sob o comando dessas funções e não preenchida pela iniciativa privada, ainda que sujeita a pressões competitivas.

\footnotetext{
${ }^{233}$ Como salientam A. SINGH (Competition and Competition Policy...op. cit), G. B. DOERN et. ali (Comparative Competition Policy...op. cit.) e E. M. M. Q. FARINA \& P. F. AZEVEDO (Política Industrial e Defesa da Concorrência: Considerações...op. cit.).

${ }^{234}$ De acordo com P. AREEDA et alii, “(...) antitrust's domain is intrinsically limited. Antitrust is not the nationalization of industry, which would reflect a decision that only direct government operation can provide the desired result. Antitrust also is not direct, extensive regulation of industry, an alternative that has been enacted for some public utilities. Rather, antitrust supplements or, perhaps, defines the rules of the game by which competition takes place (...)”. Antitrust Analysis...op. cit., p. 10.

${ }^{235}$ Entre outros, L. COUTINHO, Política de Concorrência e Desenvolvimento...op. cit., E. M. M. Q. FARINA \& P. F. AZEVEDO, Política Industrial e Defesa da Concorrência...op. cit., e J. FAGUNDES Política de Defesa da Concorrência...op. cit.
} 
Nesse ponto, por conseguinte, confirma-se a preocupação desenvolvimentista de que a ênfase excessiva na promoção e garantia das condições de concorrência representaria, de certo modo, um entrave ao desenvolvimento das economias mais atrasadas. Os argumentos em favor de que estes países se inspirem nos arranjos jurídicos adotados por Japão e Coréia durante seus respectivos processos de industrialização ${ }^{236}$ procuram justamente atenuar ou contornar o ônus decorrente dessa supervalorização da competição: apontam que a supressão da presença estatal como instância planejadora e coordenadora de estratégias para alguns setores pode perpetuar a defasagem das economias em desenvolvimento em relação aos países centrais.

Ainda que na petroquímica brasileira a conquista das pré-condições necessárias à superação dessa desvantagem possa ter assumido a aparência de significar meramente uma questão de tempo - em virtude do período transcorrido desde o processo de privatizações até a obtenção da atual configuração do setor - convém assinalar tratar-se de um tempo do qual o Brasil, e os demais países em desenvolvimento, não podem darse ao luxo de abrir mão.

\footnotetext{
${ }^{236}$ E que se desdobram, no plano teórico, na idéia de ampliar o campo de visão sobre os processos competitivos, de modo a incorporar a perspectiva da transformação econômica (ou dinâmica) que é própria do desenvolvimento capitalista, e na admissão da possibilidade de convivência entre diferentes instrumentos de coordenação dos mercados, antitruste e política setorial.
} 


\section{REFERÊNCIAS BIBLIOGRÁFICAS}

ABRAMOVAY, R., Entre Deus e o Diabo: Mercados e Interação Humana nas Ciências Sociais, Tempo Social - Revista de Sociologia da USP, vol. 16, n. 2, (2005).

AREEDA, P., \& KAPLOW, L, Antitrust Analysis - Problems, Texts, Cases, $4^{\mathrm{a}}$ ed., Boston, Little Brown and Co.,1988.

BORK, R., The Antitrust Paradox, New York, Basic Books, 1978.

BRUNA, S. V., O Poder Econômico e a Conceituação do Abuso em seu Exercício, São Paulo, RT, 1997.

BUDZINSKI, O., Pluralism of Competition Policy and the Call for Regulatory Diversity, 2003, acessível em http://papers.ssrn.com/sol3/papers.cfm?abstract_id452900

CÁRIO, S. A. F., A Relação Público-Privada na Indústria Petroquímica Brasileira: da Estruturação Articulada à Reestruturação Incerta, Campinas, Universidade Estadual de Campinas, 1997, (Tese de Doutoramento apresentada ao Instituto de Economia).

CHANG, H., J., El Papel del Estado en el Cambio Económico, México, D.F., Ariel, 1996.

CHANG, H., J., The Economics and Politics of Regulation, in Cambridge Journal of Economics, 21 (1997), pp. 703-728.

CHANG, H. J., Kicking Away the Ladder - Development Strategy in Historical Perspective, Londres, Anthem Press, 2002.

CHUDNOVSKY, D. \& LÓPEZ, A. (coord.), Auge y Ocaso del Capitalismo Asistido: La Industria Petroquímica Latinoamericana, Santiago de Chile, CEPAL/IDCR/Alianza Editorial, 1997.

COLEMAN, J., Economics and The Law: A Critical Review of The Foundations of The Economic Approach to Law, in Ethics, vol. 94, n. 4, jul (1984), pp. 649-679.

COUTINHO, L., Política de Concorrência e Desenvolvimento, Valor Econômico, 02/07/2004.

DHUMAlE, R. \& SINGH, A., Competition Policy, Development and Developing Countries, in Trade-Lated Agenda, Development and Equity - working papers, Cambridge, South Centre, (1999).

DOERN, G. B. \& WILKIS, S. (eds), Comparative Competition Policy - National Institutions in a Global Market, Oxford, Claredon Press, 2001. 
DUMONT, L., Homo Aequalis - Gênese e Plenitude da Ideologia Econômica (trad. J. L. Nascimento), Bauru, EDUSC, 2000.

ERBER, F. e VERMULM, R., Os Determinantes Estruturais do Setor Petroquímico, Ajuste Estrutural e Estratégias Empresariais, IPEA, Rio de Janeiro, n.144 (1993).

ERBER, F. S. e de OLIVEIRA, J. C., A Indústria Petroquímica Brasileira: Uma Perspectiva Histórica, Mimeo.

ERBER, F., Desarrollo y Reestructuración de La Petroquímica Brasileña in Auge y Ocaso del Capitalismo Asistido: La Industria Petroquímica Latinoamericana, D. CHUDNOVSKY \& A. LÓPEZ (coord.), Santiago de Chile, CEPAL/IDCR/Alianza Editorial, 1997.

EVANS, P., Autonomia e Parceria - Estados e Transformação Industrial, (Trad. C. B Tigres), Rio de Janeiro, UFRJ, 2005.

FAGUNDES, J., Políticas Industrial e de Defesa da Concorrência no Japão, Revista do Ibrac (1998).

FAGUNDES, J., Políticas de Defesa da Concorrência e Política Industrial: Convergência ou Divergência?, in Revista do IBRAC, v. 5, n. 6 (1998), pp. 19-41.

FARINA, E. E. M. Q., Política Industrial e Política Antitruste: Uma proposta de Conciliação, in Revista do Ibrac, v. 3, n. 8, (1996), pp. 34-64.

FARINA, E. E. M. Q. et. al., Competitividade: Mercado, Estado e Organizações, São Paulo, Singular, 1997.

FARINA, E. E. M. Q., e AZEVEDO, P. F., Política Industrial e Defesa da Concorrência: Considerações sobre a Experiência Brasileira nos Anos 1990, Revista da Associação Nacional de Centros de Pós-Graduação em Economia - ANPEC, v. 2, n. 2, jul/dez (2001), pp. 513-547.

FERRAZ JR., T. S. Lei de Defesa da Concorrência - Origem Histórica e Base Constitucional, in Revista dos Mestrandos em Direito Econômico da UFBA, n. 2, pp.6574.

FERRAZ JR., T. S., Da Abusividade do Poder Econômico, in Revista de Direito Econômico, n.21, out/dez (1995).

FOLHA DE SÃO PAULO, 20/03/2007, Petrobrás, Ultra e Braskem fatiam Ipiranga.

FOLHA DE SÃO PAULO, 26/04/2007, CADE revê sua decisão contra venda da Ipiranga, caderno Dinheiro.

FOLHA DE SÃO PAULO, 16/08/2007, Investimento em petroquímica deve crescer $220 \%$, diz BNDES, caderno Dinheiro. 
FOLHA DE SÃO PAULO, 01/12/2007, Unipar e Petrobrás criam nova empresa, caderno Dinheiro.

FOLHA DE SÃO PAULO, 05/12/2007, Lula quer ação maior em petroquímica, Caderno Dinheiro.

FONTENELE, A. M. C., Progresso e Método na História das Teorias da Organização Industrial, São Paulo, FEA-USP, 1995. (Tese de Doutoramento).

FORGIONI, P. A, Os Fundamentos do Antitruste, São Paulo, RT, 1998.

GAZETA MERCANTIL, 19/03/2007, A-4.

GERBER, D. J., Law and Competition in Twentieth Century Europe: Protecting Prometheus, Oxford, Oxford University Press, $2^{a}$ ed., 2003 [orig. 1997].

GOMES, G. et. al., Indústria Petroquímica Brasileira: Situação Atual e Perspectivas, BNDES Setorial, Rio de Janeiro, n. 21, março (2005), pp. 74-104.

GRAU, E. R., A Ordem Econômica na Constituição de 1988 - Interpretação e Crítica, $7^{a}$ ed., São Paulo, Malheiros, 2002.

GRAU, E. R., Direito, Conceitos e Normas Jurídicas, São Paulo, RT, 1988.

GUERRA, O. F., Estrutura de Mercado e Estratégias Empresariais: O Desempenho da Petroquímica Brasileira e suas Possibilidades Futuras de Inserção Internacional, Brasília, SESI-DN, 1994.

HAYEK, F. V., The Meaning of Competition, in Individualism and Economic Order, Chicago, University of Chicago, 1980.

HOVENKAMP, H., Federal Antitrust Policy - The Law of Competition and Its Practice, Saint Paul, West Publishing, 1994.

LÓPEZ, A., Mercados, Coordinación y Jerarquías, in Auge y Ocaso del Capitalismo Asistido: La Industria Petroquímica Latinoamericana, D. CHUDNOVSKY \& A. LÓPEZ (coord.), Santiago de Chile, CEPAL/IDCR/Alianza Editorial, 1997.

MOTTA, M., Competition Policy - Theory and Practice, New York, Cambridge University Press, 2004.

NUSDEO, A. M. O., Defesa da Concorrência e Globalização Econômica: O Controle da Concentração de Empresas, São Paulo, Malheiros, 2002.

O ESTADO DE SÃO PAULO, 16/07/2007, Concentração industrial aumenta no País: Movimento foi mais forte nas áreas de petroquímica e química, revela trabalho de exConselheira do Cade. 
O ESTADO DE SÃO PAULO, $R \$ 10$ bi dão nova cara à petroquímica - Petrobrás, Braskem e Unipar surgem como líderes na petroquímica, ao final de três negociações bilionárias concluídas ontem, p. b-12.

OLIVEIRA, G., Concorrência: Panorama no Brasil e no Mundo, São Paulo, Saraiva, 2001.

PARISI JR., C., O Problema da Competitividade da Indústria Petroquímica Brasileira: Um Estudo Sobre o Padrão de Integração das Firmas, São Paulo, FEA-USP, 1994 (Dissertação de Mestrado).

PETERS, G. G., US Competition Policy Institutions, in G. B. DOERN \& S. WILKIS (eds), Comparative Competition Policy - National Institutions in a Global Market, Oxford, Claredon Press, 2001.

PHAM, A., National Champions - National Interests Vs. Competition: Where to Strike the Balance, Centre for Competition, Investment \& Economic Regulation (CUTS), Briefing Paper n. 8, (2003).

POSSAS, M. L., Economia Normativa e Eficiência: Limitações e Perspectivas na Aplicação Antitruste, in Ensaios Sobre Economia e Direito da Concorrência (M. L. POSSAS coord.), São Paulo, Singular, 2002.

POSSAS, M. L., Estruturas de Mercado em Oligopólio, São Paulo, HUCITEC, 1985.

POSSAS, M. L. et alii, Política Antitruste Sob Um Enfoque Schumpeteriano, in Ensaios Sobre Economia e Direito da Concorrência, São Paulo, Singular, 2002.

POSSAS, S., Concorrência e Competitividade - Notas Sobre a Estratégia e Dinâmica Seletiva na Economia Capitalista, São Paulo, Hucitec, 1999.

SAlOMÃO FILHO, C., Direito Concorrencial - As Estruturas, 2a . ed., São Paulo, Malheiros, 2002.

SCHAPIRO, M. G, Política Industrial e Disciplina da Concorrência Pós-Reformas de Mercado: Uma Avaliação Institucional do Ambiente de Inovação Tecnológica, São Paulo, FD-USP (Dissertação de Mestrado), 2005.

SCHUMPETER, J. A., Capitalismo, Socialismo e Democracia, Rio de Janeiro, Fundo de Cultura, 1961[ed. Orig. 1942]

SCHUTTE, G. R., Elo Perdido- Estado, Globalização e Indústria Petroquímica no Brasil, São Paulo, Annablume, 2006.

SICSÚ, A. B. \& MELO, M. O. L., Competitividade, Política de Defesa da Concorrência e Soberania Nacional: Avaliações Sobre o Caso Brasileiro, in CADE Informa $\quad \mathrm{n}^{\mathrm{o}} \quad 6, \quad$ maio, (2007), disponível em http://www.cade.gov.br/news/n006/artigo.htm. 
SINGH, A., Competition and Competition Policy in Emerging Markets: International and Developmental Dimensions, G-24 - Discussion Paper $\mathrm{n}^{\mathrm{o}} 18$, United Nations Conference on Trade and Development, (2002).

SUAREZ, M. A., Petroquímica e Tecnoburocracia - Capítulos do Desenvolvimento Capitalista no Brasil, São Paulo, HUCITEC, 1986.

VALOR ECONÔMICO, 19/04/2007, CADE aprova restrições à compra da Ipiranga.

VALOR ECONÔMICO, 19/09/2007, Petrobrás e Unipar analisam integração do BNDES na CPS.

VAZ, I., Direito Econômico da Concorrência, Rio de Janeiro, Forense, 1993.

WILLIAMSON, O. E., The Economic Institutions of Capitalism, New York, Free Press, 1987.

YAZBEK, O., Política Econômica, Legislação Societária e a Aplicação do Direito da Concorrência no Brasil, in RDM, v. 39, n. ${ }^{\circ}$ 117, jan/mar (2000), PP. 136-49. 